\title{
ESTUDO DA REPARAÇÃO DO ALVÉOLO DENTAL DE RATOS WISTAR PREENCHIDO COM OSSO AUTÓGENO PARTICULADO APÓS EXODONTIA
}

Dissertação de mestrado apresentada ao Instituto de Ciências Biomédicas da Universidade de São Paulo, para obtenção do Título de Mestre em Ciências. 


\section{ESTUDO DA REPARAÇÃO DO ALVÉOLO DENTAL DE RATOS WISTAR PREENCHIDO COM OSSO AUTÓGENO PARTICULADO APÓS EXODONTIA}

Dissertação de mestrado apresentada ao Instituto de Ciências Biomédicas da Universidade de São Paulo, para obtenção do Título de Mestre em Ciências.

Área de concentração: Ciências Morfofuncionais.

Orientador: Prof. Dr. Bruno König Júnior

\section{SÃO PAULO}


DADOS DE CATALOGAÇÃO NA PUBLICAÇÃO (CIP)

Serviço de Biblioteca e Informação Biomédica do

Instituto de Ciências Biomédicas da Universidade de São Paulo

(C) reprodução total

Melo, Alexandre de.

Estudo da reparação do alvéolo dental de ratos Wistar preenchido com osso autógeno particulado após exodontia / Alexandre de Melo. -- São Paulo, 2007.

Orientador: Bruno König Júnior.

Dissertação (Mestrado) - Universidade de São Paulo. Instituto de Ciências Biomédicas. Departamento de Anatomia. Área de concentração: Ciências Morfofuncionais. Linha de pesquisa: Implantes e exertos dentais osteointegração e biocompatibilidade.

Versão do título para o inglês: Study of the alveolar wound healing grafted with particulated autogenous bone after tooth extraction in Wistar rats.

Descritores: 1. Extração dentária 2. Enxerto ósseo 3. Reparação alveolar 4. Reparo ósseo 5. Enxerto autógeno 6. Regeneração óssea I. König Júnior, Bruno II. Universidade de São Paulo. Instituto de Ciências Biomédicas. Programa de Pós-Graduação em Ciências Morfofuncionais III. Título. 


\section{DEDICATÓRIA}

Dedico este trabalho aos meus pais, Marlene Carneiro de Melo e Luiz de Melo Júnior, a minha avó Nilza Carneiro e a minha namorara Caroline Schneider, por todo amor, incentivo e confiança. 


\section{AGRADECIMENTOS}

Aos meus amados pais pelo apoio, amor e confiança sempre depositados sobre mim, exemplos de integridade e sabedoria.

À minha avó querida, Nilza Carneiro, por todo o carinho, amor e confiança vivenciados comigo.

Ao meu grande amor, Caroline Schneider, pelo carinho, cumplicidade, compreensão e incentivo em todo o período de desenvolvimento do mestrado.

Ao professor Renato Paulo Chopard, por todos os momentos de amizade, ensino e orientação compartilhados comigo.

Ao professor Bruno König Júnior, pela orientação, apoio e confiança em meu trabalho para concretização do mestrado.

Ao professor Luís Ronaldo Picosse, por todo o carinho e atenção prestados a mim. Sem dúvida alguma, conviver ao lado dele me transformou em uma pessoa melhor.

Aos professores Edson Aparecido Liberti e Sílvia de Campos Boldrini, pela amizade e ajuda para estabelecer a metodologia da análise morfométrica.

Aos professores Renato Paulo Chopard, Luís Ronaldo Picosse, Edson Aparecido Liberti, Sílvia de Campos Boldrini e Richard Halti Cabral, por serem os maiores responsáveis pelo meu aprendizado e admiração pela Anatomia Humana.

Aos professores Waltercides Silva Júnior e José Roberto Pimenta de Godoy, por terem proporcionado a mim a base do conhecimento da Anatomia Humana e incentivado a realização do Mestrado.

Ao professor Jackson Cioni Bittencourt, pela ajuda no início do mestrado. 
A professora Maria Luíza Barreto Chaves, pela amizade e pelas conversas enriquecedoras sobre pesquisa científica.

Aos queridos amigos Dorival Terra Martini, José Alexandre Magrini Pigatto, Márcia Sanae Mizuno e Maurício Cláudio de Lima, por terem sido minha família enquanto morei em São Paulo, compartilhando comigo os melhores momentos que vivenciei nessa cidade.

Aos grandes e inesquecíveis amigos de pós-graduação, Guilherme Cotomacci, Flávio Silva Tampelini, Eduardo Henrique Beber, Ricardo Bandeira, Marcelo Ferreira Calderon, Willian Grassi Bautz, Cibele Maciel de Miranda, Mateus Elias Pacheco, Amanda Cândido da Silva, Ana Cláudia da Silva Barbosa, Lincoln Beringui, Gisele Reisdoerfer, Luciano Gonçalves, William Paganini Mayer, Josemberg da Silva Baptista, Carlos Eduardo Seyfert, Renata Gonçalves de Vasconcelos, Leila Maria Guissoni Campos, Maria Tereza Jordão, Patrícia Eriko Tamae, Marcos Barbosa Salles, por todos os momentos de ajuda, diversão, cumplicidade e incentivo.

Aos demais colegas de pós-graduação, Flávia de Oliveira, Mônica Rodrigues de Souza, Priscila Azevedo Girotti, Rúbia Misawa, Telma Parada, Kleber Fernando Pereira, Maria Alicia Carillo Sepúlveda, Gabriela Diniz Placoná, Luana dos Anjos Ramos, Marcela Carneiro, Fátima Rodrigues de Sousa Freitas e Luciane Capelo.

A técnica do laboratório de Histologia, Marta Maria da Silva Riguetti, por todo o tempo desprendido a me ensinar parte dos procedimentos laboratoriais necessários para realização desse trabalho.

A professora Maria Inês Nogueira, responsável pelo laboratório de neurociências do departamento de Anatomia da USP, por permitir o uso do microscópio para análise histológica das amostras.

A professora Cecília Helena Azevedo Gouveia Ferreira, por disponibilizar o microscópio do laboratório de metabolismo ósseo para análise histológica das amostras.

Aos técnicos de Anatomia, Everton Luís Pavan Torres, Adevair Urenha Alves, Edison Dantas da Silva, José Adão Mendes, José Amaro Martins (in memoriam), Milton Pereira da 
Silva e Carlos Roberto Caldas Pedro, por toda a disponibilidade oferecida durante as aulas práticas de Anatomia Humana.

Aos funcionários do Biotério, Alessandro Rodrigo Martins, Renivaldo de Souza, Fábio França Luiz e Luciana Monteiro Silva, que cuidaram do bem mais precioso para realização do trabalho: os animais.

A todos aqueles que contribuíram de alguma forma para realização desse trabalho, cujos nomes não foram citados. 


\section{RESUMO}

\section{ESTUDO DA REPARAÇÃO DO ALVÉOLO DENTAL DE RATOS WISTAR PREENCHIDO COM OSSO AUTÓGENO PARTICULADO APÓS EXODONTIA}

Após a perda de um dente observa-se uma reabsorção óssea paulatina e contínua do processo alveolar tanto na maxila quanto na mandíbula. A anatomia desfavorável da margem óssea reabsorvida é fator limitante para reabilitação da área desdentada com próteses sobre implantes dentais osteointegráveis. O preenchimento do alvéolo dental após a exodontia com enxertos ósseos e/ou biomateriais consiste em uma tentativa de retardar a reabsorção fisiológica do processo alveolar e de estimular a neoformação óssea. O objetivo deste trabalho é investigar a influência do enxerto ósseo autógeno particulado no processo de reparo ósseo do alvéolo dental de Rattus Norvegicus Albinus da linhagem Wistar após exodontia. Foram utilizados 67 ratos, machos e com massa corpórea variando entre 190 g e 250 g. Os animais foram divididos em um grupo controle e outro experimental. Os ratos do grupo controle foram submetidos à intervenção cirúrgica para exodontia do incisivo superior direito apenas, enquanto nos ratos do grupo experimental foram realizadas a exodontia e enxertia óssea no alvéolo dental. O enxerto ósseo foi proveniente do osso ilíaco dos próprios animais. Ao atingir o $7^{\circ}, 14^{\circ}$ e $21^{\circ}$ dias de pós-operatório, alguns ratos receberam aplicações subcutânea do marcador de ossificação calceína dissolvido em solução de bicarbonato de sódio $2 \%$. A eutanásia dos ratos foi realizada no $5^{\circ}, 15^{\circ}, 21^{\circ}$ e $28^{\circ}$ dias de pós-operatório. Posteriormente à eutanásia foram removidas e reduzidas as partes ósseas que contém o alvéolo dental de cada maxila direita. As amostras obtidas foram fixadas e processadas para análise histológica. A densidade de área ocupada por osso foi quantificada por um método de contagem diferencial de pontos e com auxílio de um programa de análise de imagens. Os dados obtidos foram analisados estatisticamente e mostraram que houve um aumento progressivo da densidade de 
área ocupada por osso em função dos tempos pós-operatórios e a morfometria da densidade de área ocupada por osso nos grupos controle e experimental não apresentaram diferenças estatísticas em nenhum dos tempos pós-operatórios. Concluiu-se que o enxerto ósseo autógeno não promoveu um aumento estatisticamente significativo da neoformação óssea no alvéolo dental após exodontia nos períodos pós-operatórios estudados.

Palavras-chave: Extração dentária; Enxerto ósseo; Reparação alveolar; Reparo ósseo; Enxerto autógeno; Regeneração óssea. 


\section{ABSTRACT \\ STUDY OF THE ALVEOLAR WOUND HEALING GRAFTED WITH PARTICULATED AUTOGENOUS BONE AFTER TOOTH EXTRACTION IN WISTAR RATS}

After tooth extraction a continuous bone resorption of the alveolar process is observed in the maxilla and in the mandible. The unfavorable anatomy of the reabsorbed bone ridge limits the rehabilitation of the edentulous area with prostheses over dental implants. Filling the dental alveolus after the exodontia with bone grafts and/or biomaterials is a procedure that tries to delay the physiologic resorption of the alveolar process and stimulates bone formation. The aim of this study is to investigate the influence of the particulated autogenous bone graft in the alveolar socket healing following tooth extraction in Rattus Norvegicus Albinus lineage Wistar. Sixty-seven male rats were used, each weighing 190 to $250 \mathrm{~g}$. The animals were divided in a control and an experimental group. The upper right incisor was extracted in the rats of both groups. Following the tooth extraction, in the animals of the experimental group, the socket was grafted with particulated autogenous bone. The bone graft was obtained from the iliac bone of the same grafted animal. At 7, 14 and 21 days of postoperative, some rats received subcutaneous applications of the ossification marker calcein dissolved in a sodium bicarbonate $2 \%$ solution. The euthanasia of the animals was accomplished in the $5^{\text {th }}, 15^{\text {th }}, 21^{\text {st }}$ and $28^{\text {th }}$ days of postoperative. After the euthanasia the bone parts that contain the dental socket of each right maxilla were removed and reduced to small samples. All the samples were then fixed and processed for histological analysis. The total area of bone was quantified in the socket by a differential point-counting method and by use of an image analyzing program. The data were analyzed statistically and showed that there was a progressive increase of the bone total area during the postoperative periods. However, the morphometric analysis of the total area of bone in the control and experimental groups, did not show a 
significant statistical difference in none of the postoperative periods. The results reveal that the autogenous bone graft did not promote a significant increase of the bone new formation in the dental socket following tooth extraction.

Key words: Tooth extraction; Bone graft; Extraction wound healing; Bone repair; Autogenous graft; Bone regeneration. 


\section{SUMÁRIO}

1. INTRODUÇÃ̃O

2. REVISÃO DA LITERATURA........................................................................ 19

2.1 Reparação do alvéolo dental após exodontia..................................................... 19

2.2 Cronologia da reparação do alvéolo dental após exodontia no homem................ 22

2.3 Cronologia da reparação do alvéolo dental após exodontia no homem................ 23

2.4 Fatores que interferem na reparação do alvéolo dental........................................ 26

2.4.1 Diabetes mellitus............................................................................ 27

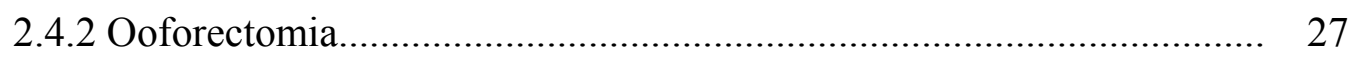

2.4.3 Fatores inerentes ao procedimento cirúrgico de exodontia................... 27

2.4.4 Influência da saliva......................................................................... 29

2.4.5 Influência do estresse..................................................................... 30

2.4.6 Implantes intra-alveolares com materiais de enxerto............................ 30

2.5 Marcadores de ossificação................................................................................. 35

2.6 Enxerto ósseo autógeno............................................................................ 35

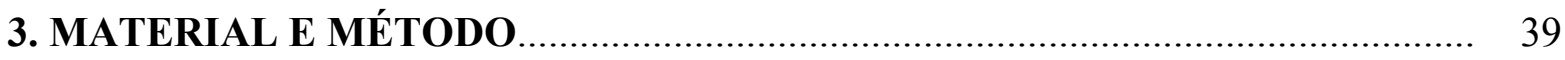

3.1 Modelo experimental.................................................................................. 39

3.2 Protocolo cirúrgico.................................................................................... 39

3.3 Medicação pós-operatória................................................................................ 45

3.4 Aplicação de marcador de ossificação.................................................................. 45

3.5 Protocolo de eutanásia................................................................................... 45

3.6 Preparo para microscopia de luz fluorescente................................................... 46

3.7 Preparo para microscopia de luz convencional................................................... 47

3.8 Análise quantitativa da densidade de área ocupada por osso................................ 49

3.9 Análise estatística...................................................................................... 53

4. RESULTADOS

4.1 Modelo experimental........................................................................... 54

4.2 Massa corpórea dos animais......................................................................... 54

4.3 Análise qualitativa dos cortes histológicos corados com hematoxilina e eosina de Harris observados em microscópio sob luz convencional..................................... 57

4.3.1 Grupo controle............................................................................ 57

4.3.2 Grupo experimental......................................................................... 66 
4.4 Análise qualitativa dos cortes histológicos corados com picrosírius observados em microscópio sob luz polarizada.

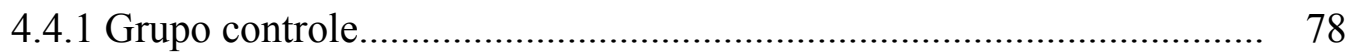

4.4.2 Grupo experimental........................................................... 82

4.5 Análise qualitativa dos cortes histológicos dos alvéolos dentais dos ratos que receberam calceína observados em microscópia sob luz fluorescente...................... 86

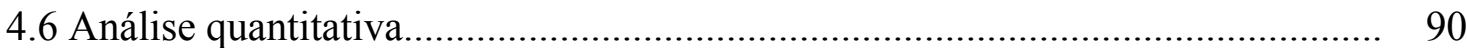

5. DISCUSSÃO

6. CONCLUSÃO

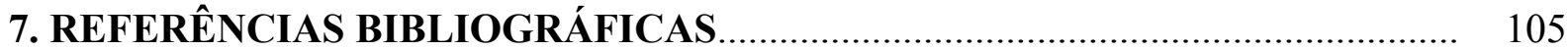




\section{INTRODUÇÃO}

A evolução da Odontologia nos últimos tempos define cada vez mais uma postura voltada a métodos de prevenção de doenças, a fim de proporcionar uma qualidade de vida melhor para os pacientes, baseando-se nos princípios da promoção da saúde. Entretanto grande parte da população ainda necessita dos tratamentos restauradores e reabilitadores oferecidos pela Odontologia, já que a evolução da cárie e da doença periodontal continuam sendo etiologias comuns da perda dental. Segundo o Ministério da Saúde (2003) cerca de 66\% da população brasileira de 35 a 44 anos de idade apresenta perda dental e esse índice se eleva a quase $93 \%$ quando avaliada a faixa etária de 65 e 74 anos.

Durante a reparação do alvéolo dental após exodontia ocorrem alterações dimensionais do osso alveolar tanto em espessura quanto em altura, devido à reabsorção e remodelagem das cristas ósseas (PIETROKOVSKI e MASSLER, 1967a; JOHNSON, 1969; JAHANGIRI et al., 1998). Devlin e Ferguson (1991) relatam que a ausência do estímulo mastigatório proporcionado pelo dente perdido sobre o osso é um dos fatores locais causador da reabsorção do osso alveolar. Todavia existe uma combinação dos fatores locais com fatores referentes à dieta, sexo, idade e ação hormonal, que determinam o grau e a velocidade da perda do osso alveolar.

Diversas pesquisas científicas foram realizadas no homem (PIETROKOVSKI e MASSLER, 1967a; JOHNSON, 1969; SCHROPP et al., 2003) e em animais, como ratos (PIETROKOVSKI e MASSLER, 1967b; GUGLIELMOTTI e CABRINI, 1985) e cães (ARAÚJO e LINDHE, 2005), com o intuito de melhor compreender o processo de reabsorção do processo alveolar depois da perda dental. Pietrokovski e Massler (1967a) e Pietrokovski e Massler (1967b) demonstraram que na maxila ocorre uma reabsorção mais pronunciada da tábua óssea vestibular do que da palatina. Johnson (1969) ainda descreve que a reabsorção 
óssea em espessura da maxila é maior do que em altura durante os períodos iniciais posteriores à extração dental. Guglielmotti e Cabrini (1985) e Pietrokovski e Massler (1967a) constataram que na mandíbula o padrão de reabsorção da tábua óssea vestibular e lingual é semelhante. Araújo e Lindhe (2005) observaram uma reabsorção mais evidente da tábua óssea vestibular mandibular em relação com a tábua lingual, o que é diferente dos resultados encontrados por Guglielmotti e Cabrini (1985) e Pietrokovski e Massler (1967a).

Schopp et al. (2003) relatam que as maiores alterações do processo alveolar no homem ocorrem nos primeiros 12 meses após a extração dental, sendo que aproximadamente dois terços da reabsorção óssea acontecem até o terceiro mês. Araújo e Lindhe (2005) observaram em cães que as maiores alterações dimensionais do osso alveolar ocorrem durante o período compreendido entre 4 e 8 semanas depois da exodontia.

A preservação do osso alveolar após a perda dental é essencial para o sucesso do tratamento com implantes dentais. Lekovic et al. (1997) e Lekovic et al. (1998) usaram a regeneração óssea guiada com uso de membranas de politetrafluoroetileno (ePTFE) nãoabsorvível e de polímero de glicolídeo e lactídeo bioabsorvível, respectivamente, com o intuito de diminuir a reabsorção óssea. Ambos os trabalhos concluíram que o uso dessas membranas preserva o osso alveolar depois da exodontia quando comparado ao grupo controle onde não foram usadas as membranas.

O uso de próteses sobre implantes dentais osteointegrados atua em papel de destaque no tratamento reabilitador de ausências dentais, garantindo a recuperação da função mastigatória, boa estabilidade para prótese e estética satisfatória ao paciente. Segundo Widmark et al. (1997) boa estabilidade inicial, volume ósseo suficiente e qualidade adequada do osso são os 3 fatores que influenciam o resultado clínico da cirurgia de implante dental, sendo que a falta de volume ósseo suficiente é fator limitante para colocação de implantes. 
Portanto, o grau de reabsorção óssea do processo alveolar após a exodontia deve ser avaliado criteriosamente pelo cirurgião-dentista por meio do exame clínico, radiológico e tomográfico da região desdentada, a fim de se obter maior previsibilidade no tratamento de reabilitação com implantes dentais osteointegráveis. Caso as dimensões ósseas do rebordo alveolar estejam aquém das necessárias, técnicas de reconstrução de defeitos ósseos utilizando-se enxertos ósseos e biomateriais podem ser consideradas no planejamento cirúrgico rotineiro.

Van den Bergh et al. (1998) relatam que as cirurgias prévias à instalação de implantes oferecem a oportunidade de "recriar" uma condição anatômica mais ou menos ideal do processo alveolar. Triplett e Schow (1996) afirmam que não é mais aceitável que a colocação de implantes seja realizada fora dos padrões ideais por causa da anatomia desfavorável do local cirúrgico.

A fim de melhor compreender a reparação óssea após a extração dental, todos os ensaios científicos que elucidem ainda mais os eventos fisiológicos que ocorrem no alvéolo dental tornam-se válidos e necessários. O aprimoramento dessas pesquisas possibilita conhecer os efeitos da reabsorção óssea do processo alveolar, assim como descobrir se é possível minimizar a perda óssea indesejada e/ou aumentar a quantidade de osso formado com auxílio de enxertos ósseos e biomateriais.

O objetivo deste trabalho é investigar a influência do enxerto ósseo autógeno particulado no processo de reparo ósseo do alvéolo dental de ratos Wistar após exodontia. 


\section{REVISÃO DA LITERATURA}

\subsection{REPARAÇÃO DO ALVÉOLO DENTAL APÓS EXODONTIA}

A reparação do alvéolo dental após exodontia tem sido amplamente pesquisada pelo meio científico em diferentes espécies animais: cão (EULER, 1923; CLAFLIN, 1936; HUEBSCH e HANSEN, 1969; CARDAROPOLI et al. 2003), rato (SMITH, 1958; TODO, 1968a; McMILLAN, 1971; MAGALHÃES et al.1982; OKAMOTO et al., 1994; TANAKA et al. 2001), macaco (SIMPSON, 1960a, 1960b, 1961a, 1961b), coelho (KURITA et al. 1985; OCAÑA, 2001; LALANI et al. 2004; TAMAE, 2005), porco da Índia (JOHANSEN e GILHUUS-MOE, 1969) e homem (AMLER et al., 1960; SOEHREN e SWOL, 1979; EVIAN et al. 1982; BECKER, 1996; DEVLIN e SLOAN, 2002; MUNHOZ, 2005). A determinação da cronologia da reparação do alvéolo dental nas variadas espécies animais pôde ser verificada utilizando-se métodos histológicos (SIMPSON, 1960; GRANDINI et al. 1970; CARVALHO et al. 1983, LALANI et al. 2003), radiológicos (HUEBSCH et al., 1952; DALITZ, 1964; SMITH, 1974; CARVALHO et al., 1980; BODNER et al., 1993) e histoquímicos (AMLER et al. 1960; TODO, 1968b; OKAMOTO e RUSSO, 1973).

Verificou-se nesses estudos que a seqüência dos eventos envolvidos na reparação alveolar é semelhante para as diferentes espécies avaliadas. Entretanto, cada espécie apresenta diferentes períodos de tempo para concluir todo o processo de reparo. A partir do exposto, a descrição dos mecanismos envolvidos durante a reparação do alvéolo dental após exodontia pode ser realizada de forma geral, abrangendo as diferentes espécies animais, incluindo o homem.

O processo de reparação do alvéolo dental é observado imediatamente após a exodontia. Inicialmente o alvéolo é preenchido por sangue proveniente do rompimento dos vasos do ligamento periodontal e do feixe vascular do dente. O coágulo sangüíneo que se 
forma ocupa dessa maneira o espaço onde previamente encontrava-se a porção radicular do dente (EULER, 1923; SIMPSON, 1969; CARVALHO e OKAMOTO, 1978; KUBOKI et al.,1988; OKAMOTO et al. 1994; CARDAROPOLI et al. 2003).

Gradualmente o coágulo sangüíneo é invadido por fibroblastos, capilares neoformados e células inflamatórias como linfócitos e neutrófilos, caracterizando o tecido de granulação. A proliferação desses componentes ocorre a partir das paredes e parte apical do alvéolo, admitindo-se que as fibras remanescentes do ligamento periodontal atuem ativamente na formação desse tecido conjuntivo (JOHANSEN, 1970; OKAMOTO E RUSSO, 1973; CARVALHO et al., 1983; CARVALHO e OKAMOTO, 1987; LIN et al., 1994; KANYAMA et al., 2003). Durante os primeiros dias após a extração dental é possível observar a presença de osteoclastos nas cristas ósseas alveolares (CLAFLIN, 1936; JOHANSEN, 1970; SMITH, 1974; HSIEH et al., 1994; ARAÚJO e LINDHE, 2005).

Os osteoblastos são as células responsáveis pela síntese da parte orgânica da matriz óssea (JUNQUEIRA e CARNEIRO, 2004). Células osteoprogenitoras encontradas no ligamento periodontal do alvéolo são responsáveis pela diferenciação de osteoblastos (LIN et al., 1994; ISAKA et al., 2001; DEVLIN e SLOAN, 2002). Os osteoblastos que se encontram no alvéolo dental depositam paulatinamente matriz orgânica, dando origem ao osteóide. A partir da calcificação do osteóide surgem trabéculas ósseas delgadas. A deposição contínua de minerais sobre as trabéculas permite o preenchimento de toda extensão do alvéolo, com constante espessamento das mesmas, diminuindo o espaço intertrabecular. Este processo é finalizado com a organização do osso em lamelas, característica de maturidade óssea plena (AMLER et al., 1960; EVIAN et al., 1982; CARDAROPOLI et al., 2003).

A deposição inicial de osso para reparação alveolar tem início nas corticais internas e no fundo do alvéolo. Além disso, alterações extra-alveolares como deposição óssea ao longo da área cortical externa subperiosteal do alvéolo e adjacente aos espaços medulares também 
são observadas concomitantes ao reparo intra-alveolar (BOYNE e KRUGER, 1962; BOYNE, 1966; TODO, 1968; ASTRAND e CARLSSON, 1969). Astrand e Carlsson (1969) afirmam que essa formação óssea extra-alveolar pode ser um mecanismo compensatório às mudanças nas condições locais do alvéolo ou um mecanismo de reforço do processo alveolar após a perda dental.

A proliferação e maturação das fibras colágenas no interior do alvéolo dental após exodontia serve como arcabouço para deposição mineral e formação das trabéculas ósseas (KUBOKI et al., 1988; DEVLIN et al., 1997). O colágeno é o tipo de proteína mais numerosa encontrada no organismo, correspondendo a $30 \%$ da massa corpórea seca. Atualmente mais de 20 tipos de colágenos geneticamente diferentes são encontrados na pele, osso, cartilagem, músculo liso e lâmina basal. O colágeno tipos I, III e V participam da formação estrutural do tecido ósseo, sendo que o tipo I é o mais abundante deles (JUNQUEIRA e CARNEIRO, 2004).

Kurita et al. (1985) relatam que o colágeno tipos I, III e V atuam diretamente na reparação do alvéolo dental. Devlin et al. (1995) e Devlin et al. (1997) demonstram ainda a participação do colágeno tipo II na fase inicial da reparação do alvéolo. Segundo Devlin et al. (1997) o colágeno tipo II é uma proteína predominante da matriz de cartilagem hialina e desempenha papel essencial na ossificação endocondral. Entretanto, o alvéolo dental segue as características da ossificação intramembranácea, onde não há formação de cartilagem previamente à calcificação do osso. Apesar da expressão de colágeno tipo II no alvéolo, os autores concluem que essa proteína não participa do arcabouço de fibras colágenas no qual o osso imaturo se forma.

Shyng et al. (1999) demonstraram a expressão da proteína CD-RAP (cartilage-derived retinoic acid-sensitive protein) em pré-osteoblastos durante a reparação inicial do alvéolo dental após exodontia. A CD-RAP é uma proteína que é restrita à cartilagem de animais 
adultos. A expressão máxima da CD-RAP no alvéolo aconteceu após 6 ou 7 dias de pósoperatório. Os autores concluem que a participação dessa proteína específica da cartilagem na reparação alveolar pode indicar níveis moleculares similares entre as ossificações intramembranácea e endocondral.

\subsection{CRONOLOGIA DA REPARAÇÃO DO ALVÉOLO DENTAL APÓS EXODONTIA NO HOMEM}

A partir dos trabalhos de Amler et al. (1960), Dalitz (1964), Amler (1969) e Evian et al. (1982), a seqüência cronológica dos eventos ocorridos na reparação do alvéolo dental após exodontia no homem pode ser resumida do seguinte modo:

24 horas de pós-operatório: presença do coágulo sangüíneo.

2-4 dias de pós-operatório: proliferação do tecido de granulação a partir da periferia do alvéolo com diminuição da área preenchida pelo coágulo sangüíneo.

4 dias de pós-operatório: primeira evidência do início da epitelização do alvéolo dental.

7 dias de pós-operatório: substituição do coágulo sangüíneo por tecido de granulação. Presença de osteóide no terço apical do alvéolo dental. Nota-se ainda tecido conjuntivo imaturo e osteoblastos na periferia alveolar.

7-12 dias de pós-operatório: proliferação do tecido conjuntivo com substituição do tecido de granulação. Há um aumento da quantidade de vasos sangüíneos e observa-se o início da reabsorção óssea da crista alveolar.

> 15-20 dias de pós-operatório: início da mineralização e formação de trabéculas ósseas na periferia e terço apical do alvéolo.

24-35 dias de pós-operatório: epitelização completa do alvéolo dental. 
28 dias de pós-operatório (4 semanas): trabeculado ósseo mais abundante e revestido por osteóide e osteoblastos.

38 dias de pós-operatório: dois terços do alvéolo dental preenchidos por tecido ósseo.

4-8 semanas de pós-operatório: espessamento gradativo das trabéculas ósseas tornando-as mais evidentes. Diminuição aparente do número de osteoblastos e osteoclastos. Por volta do $38^{\circ}$ dia, observa-se radiograficamente o desaparecimento da lâmina dura.

8-12 semanas de pós-operatório: aumento do volume ósseo trabecular com diminuição da área ocupada por tecido conjuntivo.

12-16 semanas de pós-operatório: preenchimento de todo o alvéolo dental por tecido ósseo.

Acima de 17 semanas: remodelação óssea do alvéolo dental e processo alveolar.

\subsection{CRONOLOGIA DA REPARAÇÃO DO ALVÉOLO DENTAL APÓS EXODONTIA} NO RATO

A cronologia da reparação alveolar após avulsão dental em ratos pode ser verificada nos trabalhos de Huebsch et al. (1952), Grandini et al. (1970), Okamoto e Russo (1973), Carvalho et al. (1983), Okamoto e Fialho (1990), dentre outros. O resumo dos eventos ocorridos no processo de reparo alveolar nos dias que se sucedem à extração dental pode ser descrito da seguinte maneira:

$>24$ horas de pós-operatório: presença do coágulo sangüíneo e feixes de fibras remanescentes do ligamento periodontal.

3-5 dias de pós-operatório: proliferação de fibroblastos e capilares neoformados em direção do coágulo sangüíneo com aumento da quantidade de células inflamatórias, principalmente linfócitos e neutrófilos, formando o tecido de granulação. Sinais de 
reabsorção das paredes alveolares com a presença de osteoclastos. Início da formação óssea no $5^{\circ}$ dia de pós-operatório.

6-7 dias de pós-operatório: continuação da substituição do coágulo sangüíneo por tecido de granulação, proliferação de osteoblastos na periferia do alvéolo e formação de trabéculas ósseas delgadas nos terços apical e em parte do médio.

$>$ 9-10 dias de pós-operatório: presença de tecido conjuntivo mais organizado, bem vascularizado e rico em fibroblastos. Espessamento das trabéculas ósseas dos terços apical e médio, tornando-as mais evidentes. Terço cervical e porção central de todo o alvéolo sem diferenciação óssea.

13-21 dias de pós-operatório: diminuição de áreas com remanescentes do coágulo sangüíneo e células inflamatórias, intensa atividade osteoblástica com formação de tecido osteóide, preenchimento gradual de todo alvéolo por trabéculas ósseas, sendo que as trabéculas próximas às corticais nos terços apical e do alvéolo são mais espessadas e bem definidas, enquanto que as do terço cervical são imaturas. Porção central do alvéolo ocupado por tecido de granulação, principalmente no terço cervical.

> 24-28 dias de pós-operatório: redução constante do tecido de granulação, ocupação gradual de todos os terços e porção central do alvéolo por trabéculas ósseas e espessamento das trabéculas com diminuição dos espaços intertrabeculares, caracterizando o início do remodelamento ósseo.

Acima de 28 dias de pós-operatório: remodelação óssea do alvéolo dental e processo alveolar.

Os períodos de tempo descritos desde a exodontia até a completa formação de osso no alvéolo dental foram determinados a partir de estudos de vários pesquisadores. A revisão da literatura revela que a maior parte dos autores dos trabalhos analisou cortes histológicos realizados no plano frontal ou sagital do longo eixo do alvéolo. 
Especificamente nas pesquisas realizadas após exodontia do incisivo superior de ratos, os resultados da análise de cortes histológicos realizados longitudinalmente ao alvéolo dental indicaram que a cronologia do processo de reparação alveolar se completa aproximadamente no $21^{\circ}$ dia de pós-operatório (MAGALHÃES et al. 1982; CARVALHO et al., 1983; ALVES e OKAMOTO, 1989; SANTOS JÚNIOR e MELHADO, 1990).

Okamoto e Fialho (1990) realizaram um estudo comparativo entre obtenção de cortes histológicos longitudinais e transversos ao longo eixo do alvéolo do dente incisivo superior direito de ratos Wistar após exodontia, incluídos em parafina. A análise histológica dos cortes dos alvéolos dos animais foi realizada em diferentes tempos pós-operatórios. Em relação aos cortes longitudinais, os autores relataram a dificuldade em conseguir cortes paralelos ao longo eixo do alvéolo, pois um pequeno desvio do bloco de parafina no micrótomo pode acarretar a perda de quase metade do alvéolo. Além disso, não se pode certificar a exata posição da porção central do alvéolo, já que os cortes provavelmente foram feitos obliquamente ao longo eixo do alvéolo. Destaca-se ainda que as paredes lateral e medial do alvéolo não são aproveitadas. A realização de cortes transversos ao alvéolo permitiu suprimir boa parte dos empecilhos. Entretanto, houve a necessidade de colher um número muito elevado de cortes histológicos. A análise desses cortes mostrou que a ocupação do alvéolo por tecido conjuntivo e trabéculas ósseas ocorre de maneira centrípeta. Concluíram categoricamente que o processo de reparo do alvéolo dental após exodontia do incisivo superior de rato se completa entre o $24^{\circ}$ e $28^{\circ}$ dias de pós-operatório.

A determinação da cronologia da reparação do alvéolo dental após exodontia utilizando-se estudos radiográficos e densitométricos fornece outros subsídios para corroborar os resultados encontrados por Okamoto e Fialho (1990). Victor et al. (1977) estabelecem radiograficamente o $30^{\circ}$ dia de pós-operatório como o término do processo de reparo alveolar após exodontia. 
Bodner et al. (1993) pesquisaram em ratos Wistar o reparo do alvéolo dental após exodontia do primeiro molar inferior esquerdo nos seguintes dias de pós-operatório: $0,7,14$, 21, 28, 45 e 60. A densitometria da parte apical dos alvéolos mostrou um aumento da densidade a partir do $7^{\circ}$ dia de pós-operatório, aumentando constantemente até o $28^{\circ}$ dia, não havendo variações significativas estatisticamente após esse período. Infere-se desses resultados que a partir do $28^{\circ}$ dia de pós-operatório o osso apresenta-se em fase de remodelação, já que não há deposição mineral suficiente no terço apical do alvéolo que proporcione alterações consideráveis na radiopacidade da imagem radiológica e não promove, portanto, variação significativa nos valores obtidos pela densitometria.

A maioria dos trabalhos sobre o reparo do alvéolo dental após exodontia restringiu-se em relatar o aspecto qualitativo envolvido no processo de reparação alveolar. A análise quantitativa dos componentes encontrados na reparação do alvéolo depois da extração dental fornece informações importantes que complementam substancialmente os achados qualitativos, valorizando o ensaio científico. Observou-se na literatura consultada análises quantitativas em estudos densitométricos (CARVALHO et al., 1980; GUGLIELMOTTI e CABRINI, 1985; BODNER et al., 1993) e histológicos (HSIEH et al., 1994; CARVALHO et al., 1997; CALIXTO, 2001; BRANDÃO et al., 2002; YUGOSHI et al. 2002; BAPTISTA, 2004; MADID, 2004; TAMAE, 2005; CARDAROPOLI et al., 2005; BAUTZ, 2006).

\subsection{FATORES QUE INTERFEREM NA REPARAÇÃO DO ALVÉOLO DENTAL}

Vários são os fatores que interferem na cronologia de reparação do alvéolo dental após exodontia. Podem ser citados como exemplos: distúrbios metabólicos como o diabetes mellitus, cirurgias experimentais como ooforectomia, fatores inerentes ao procedimento cirúrgico de exodontia, influência da saliva, estresse do indivíduo e implantes intra-alveolares com materiais de enxerto. 


\subsubsection{Diabetes mellitus}

O diabetes mellitus é uma doença metabólica caracterizada por uma deficiência absoluta ou relativa na produção de insulina pelo pâncreas. A indução experimental do diabetes em animais, seja por injeção de drogas ou pela remoção cirúrgica do pâncreas, permitiu o estudo mais detalhado das alterações provocadas pela doença no processo de reparo alveolar após extração dental. Os trabalhos conduzidos por Grandini et al.(1970), Mcmillan (1970 e 1971), Grandini (1978), Grandini et al. (1990), Devlin et al. (1996), Baptista (2004) e Madid (2004) demonstraram um atraso significativo na reparação alveolar em ratos diabéticos.

\subsubsection{Ooforectomia}

A influência da ooforectomia sobre o processo de reparo do alvéolo dental após a exodontia de ratos foi descrita nos trabalhos de Salomão et al. (1974), Hsieh et al. (1995) e Tanaka et al. (2001). Salomão et al. (1974) constataram histologicamente atraso na proliferação celular, na formação da matriz orgânica e na mineralização do alvéolo dental. Entretanto, Tanaka et al. (2001) avaliaram quantitativamente a formação óssea alveolar por meio de microscopia eletrônica de varredura e afirmaram não haver atraso significativo por causa da ooforectomia. Tanto Salomão et al. (1974), Hsieh et al. (1995) e Tanaka et al. (2001) concordam que ocorre um aumento da reabsorção da cortical óssea do alvéolo e do processo alveolar causado pela ooforectomia.

\subsubsection{Fatores inerentes ao procedimento cirúrgico de exodontia}

Em relação às interferências ocasionadas por fatores inerentes ao procedimento cirúrgico, Simpson (1957) verificou microscopicamente em macacos que a remoção com 
instrumento metálico do ligamento periodontal nas paredes do alvéolo depois da extração dental ocasiona atraso na organização do coágulo e formação óssea no alvéolo.

Carvalho et al. (1983) observaram a influência da irrigação e curetagem intra-alveolar na reparação alveolar de ratos Wistar submetidos à exodontia do incisivo superior direito. Os resultados mostraram que a irrigação do alvéolo dental com solução salina não interfere no reparo do alvéolo, enquanto que a curetagem intra-alveolar, seguida de irrigação com solução salina, promoveu um retardo evidente na reparação. Os autores concluem que a remoção do remanescente do ligamento periodontal pela curetagem intra-alveolar foi a responsável pelo atraso na reparação alveolar.

No estudo da interferência causada pela curetagem intra-alveolar após extração dental em cães, Cardaropoli et al. (2005) obtiveram resultado divergente das pesquisas de Simpson (1957) e Carvalho et al. (1983). O trabalho consistiu na exodontia bilateral do $4^{\circ}$ pré-molar mandibular de cães. Em um dos alvéolos foi realizada a curetagem da parede interna alveolar, enquanto que o outro foi considerado controle por somente ter sido executada a exodontia. Decorridos 3 meses de reparação do alvéolo dental depois da exodontia, os cães sofreram eutanásia e seus alvéolos foram preparados para análise histológica qualitativa e quantitativa. Os resultados não mostraram diferenças significativas entre os alvéolos curetados e não curetados. Os autores afirmam que os resultados não devem ser interpretados como indicativo de que as células do ligamento periodontal não são importantes, pois outros trabalhos revelam participação importante do ligamento periodontal no reparo alveolar.

Simpson (1961a e 1961b) analisou a reparação do alvéolo dental de macacos após exodontia, utilizando brocas e cinzéis para osteotomia da crista alveolar previamente à avulsão do dente. A conclusão dos trabalhos revela um aumento do infiltrado inflamatório nos primeiros dias de pós-operatório causado pela presença de fragmentos ósseos no interior do alvéolo provenientes da osteotomia na crista óssea alveolar. O uso do cinzel produziu uma 
quantidade menor de fragmentos ósseos durante a osteotomia quando comparado ao uso da broca, o que proporcionou menor reação inflamatória no alvéolo dental. O autor sugere que se irrigue o interior do alvéolo com solução salina previamente à sutura a fim de remover os fragmentos ósseos produzidos durante a osteotomia, possibilitando menos infiltrado inflamatório.

Magalhães et al. (1982) estudaram a influência da fratura de crista óssea alveolar sobre o reparo de feridas de extração dental em ratos Wistar. Concluíram que a fratura retarda o processo de reparação alveolar e sugeriram a remoção do fragmento ósseo fraturado durante o ato cirúrgico, já que ele atua como corpo estranho no local da ferida e por isso promove reação inflamatória local.

Okamoto et al. (1994) relataram a interferência do coágulo sangüíneo na formação do tecido de granulação após extração do dente incisivo superior direito de ratos Wistar. A análise histológica dos alvéolos dentais revelou um grande atraso na reparação alveolar dos animais que tiveram o coágulo sangüíneo removido após exodontia, indicando um papel importante do coágulo no mecanismo de formação do tecido de granulação.

\subsubsection{Influência da saliva}

A condição do meio oral também pode interferir na reparação do alvéolo dental após exodontia. Bodner et al. (1991) pesquisaram o processo de reparação alveolar do primeiro molar superior esquerdo após exodontia em ratos Sprague-Dawley, submetidos à ligadura bilateral dos ductos parotídeos e remoção cirúrgica das glândulas sublingual e submandibular. Foi relatado o atraso na reparação alveolar desses ratos, especificamente na substituição do coágulo sangüíneo pelo tecido de granulação, apresentando reação inflamatória mais longa. A formação óssea no alvéolo também ocorreu de forma mais lenta comparada ao grupo controle. 


\subsubsection{Influência do estresse}

Alves e Okamoto (1989) avaliaram a influência do estresse por contenção física pré e pós-cirúrgico sobre o reparo do alvéolo dental após extração dental em ratos Wistar. O atraso da reparação alveolar foi constatado tanto nos animais que sofreram estresse pré-operatório quanto nos estressados no pós-operatório. Todavia, as alterações são maiores nos animais com estresse pós-cirúrgico. Os autores sugerem que o atraso maior nesses animais pode ser explicado pela interferência do agente estressante no processo inicial do reparo, onde há formação de coágulo sangüíneo.

\subsubsection{Implantes intra-alveolares com materiais de enxerto}

Vários materiais de enxerto foram experimentalmente implantados no alvéolo dental do homem e outras espécies animais a fim de se constatar a influência que esses materiais provocariam na reparação do alvéolo dental após extração dental.

Carvalho et al. (1972) implantaram “osso sintético" no alvéolo dental depois da extração do incisivo central superior esquerdo de 13 pacientes. A exodontia do incisivo central superior direito também foi realizada, utilizando-se o alvéolo como controle. Tomadas radiográficas dos alvéolos dentais foram feitas em tempos pós-operatórios específicos. Observaram que o "osso sintético" comportou-se como agente irritante, o que retardou o processo de reparo alveolar. Além disso, a eliminação de fragmentos do enxerto foi frequentemente constatada.

Victor et al. (1975) estudaram histologicamente a influência do implante de gesso de Paris (quimicamente sulfato de cálcio) no reparo do alvéolo dental após exodontia em ratos Wistar. Foram utilizados 56 ratos divididos em um grupo controle e outro experimental. Verificaram que o gesso de Paris causa reação inflamatória intensa, reabsorção óssea e retardo da reparação alveolar. 
Calixto (2001) verificou a influência da implantação de um floculado de resina derivada do óleo de mamona em alvéolos dentais imediatamente depois da exodontia em ratos Wistar. Utilizou-se de 80 ratos divididos em grupos controle e experimental. A análise histológica quantitativa nos alvéolos dentais permitiu concluir que o material de enxerto proporcionou um atraso de 13 a $20 \%$ na formação óssea durante a reparação alveolar comparado aos alvéolos controles.

Nemcovsky e Serfaty (1996) avaliaram clinicamente em 23 pacientes a influência da hidroxiapatita não-reabsorvível em alvéolos de dentes maxilares anteriores depois da exodontia com intuito de preservação do processo alveolar. O procedimento cirúrgico incluiu a exodontia, o preenchimento do alvéolo com hidroxiapatita e o recobrimento do alvéolo com enxerto de tecido conjuntivo pediculado. A reabilitação da área desdentada foi feita com uma prótese parcial fixa. Periodicamente, por um tempo de pós-operatório de 2 anos, mensurações da distância entre o pôntico e a crista alveolar foram realizadas nos pacientes. Os resultados indicaram boa previsibilidade do tratamento para a manutenção do contorno do processo alveolar após exodontia, o que garante melhor estética da prótese. Entretanto, os autores limitam essa técnica somente para os casos nos quais não haverá reabilitação da área enxertada com implantes dentais osteointegráveis.

Brandão et al. (2002) relataram o uso de hidroxiapatita e hidroxiapatita misturada à proteína morfogenética do osso (BMP) no preenchimento do alvéolo dental após exodontia em ratos Wistar. O total de 45 animais foi utilizado no trabalho, sendo os mesmos divididos em grupo controle, grupo implantado com hidroxiapatita e grupo implantado com hidroxiapatita misturada à BMP. Os resultados mostraram que o preenchimento do alvéolo dental após exodontia com hidroxiapatita e hidroxiapatita misturada à BMP não melhorou a reparação do alvéolo dental, por retardar a formação óssea no alvéolo. 
Baptista (2004) estudou a ação do enxerto de hidroxiapatita no interior de alvéolos dentais após a exodontia em ratos Wistar diabéticos. Foram utilizados 12 animais divididos em grupos controle, diabético sem hidroxiapatita e diabético com hidroxiapatita. Os resultados quantitativos analisados estatisticamente indicaram que os grupos controle e diabético com hidroxiapatita apresentaram a mesma formação óssea no alvéolo. O grupo diabético sem hidroxiapatita apresentou menor formação de osso que os demais grupos. $\mathrm{O}$ autor concluiu que a hidroxiapatita comportou-se como estimulante da neoformação óssea no alvéolo dental.

Calixto (2005) analisou em 39 pacientes a reparação do alvéolo dental após exodontia de terceiros molares inferiores não-irrompidos preenchidos com uma associação de matriz óssea orgânica cortical e inorgânica medular, BMP's e colágeno (Gen-Tech® Baumer S.A.). No grupo experimental o alvéolo do terceiro molar de um lado foi preenchido com GenTech ${ }^{\circledR}$ e recoberto com membrana reabsorvível de osso cortical bovino liofilizado (GenDerm ${ }^{\circledR}$ Baumer S.A.). No alvéolo do lado oposto foi mantido o coágulo sangüíneo e consistiu o grupo controle. Tomadas radiográficas periapicais dos alvéolos foram realizadas em tempos pós-operatórios específicos. Medidas da distância da crista óssea alveolar à junção amelocementária e da densidade radiográfica também foram feitas. Os resultados analisados estatisticamente permitiram concluir que os alvéolos controles tiveram comportamento semelhante aos alvéolos experimentais.

Becker et al. (1994) avaliaram a capacidade de formação óssea promovida pela implantação de osso desmineralizado congelado seco (DFDBA) e osso autógeno em alvéolos dentais após exodontia. Seis pacientes participaram da pesquisa, apresentando no mínimo dois dentes comprometidos por doença periodontal e com indicação de exodontia. Depois da remoção dos dentes foi enxertado cada um dos materiais nos alvéolos remanescentes. Decorridos 3 a 13 meses da enxertia um novo procedimento cirúrgico foi realizado para 
coletar biópsias da área enxertada e instalação de implantes dentais osteointegráveis. A análise histológica das amostras coletadas indicou que o DFDBA interfere atrasando a formação normal de osso no alvéolo, pois não houve evidência de atividade osteogênica ao redor do enxerto. Já o enxerto de osso autógeno viabilizou uma formação óssea ativa com a presença de osso imaturo e lamelar circundando os fragmentos do enxerto, que ocasionalmente eram não-vitais.

Becker et al. (1996) conduziram um estudo em 15 pacientes e verificaram a influência do preenchimento com osso autógeno, DFDBA e osso mineralizado congelado seco (MFDBA) na reparação de alvéolos dentais depois da exodontia. Biópsias das áreas enxertadas foram realizadas entre 4 e 12 meses de pós-operatório. Observaram microscopicamente que havia osso maduro do leito receptor ao redor das partículas de enxerto ósseo autógeno com poucas células inflamatórias. Fragmentos de osso vital e não-vital também foram identificados. As amostras com DFDBA consistiram de fragmentos ósseos não-vitais circundados por poucas células inflamatórias. Os enxertos com MFDBA mostraram partículas de osso vitais e não-vitais sem evidências de atividade osteoblástica ou osteoclástica ao redor ou adjacente aos fragmentos de enxerto. Os autores concluíram que os materiais de enxerto estudados não apresentaram melhorias apreciáveis à formação óssea dos alvéolos dentais.

Becker et al. (1998) relataram a reparação do alvéolo dental de 8 pacientes após exodontia submetidos ao preenchimento com osso bovino inorgânico, DFDBA, osso autógeno e uma combinação de proteína morfogenética do osso (BMP) com proteínas não-colágenas do osso (NCP). Em 5 pacientes o total de 5 alvéolos dentais recebeu osso bovino inorgânico, 3 foram implantados com DFDBA, 3 com osso autógeno e 2 com a combinação de BMP/NCP. Após a extração dos dentes de 3 pacientes foram instalados no alvéolo micro-parafusos de titânio. Em 3 alvéolos foi implantado ao redor do micro-parafuso osso bovino inorgânico, em 
2 o preenchimento foi realizado com DFDBA e em 1 utilizou-se osso autógeno. Biópsias das áreas enxertadas com ou sem micro-parafusos foram coletadas de 3 a 7 meses de pósoperatório. Por meio da análise histológica da amostras foi possível observar que o alvéolo implantado com DFDBA apresentava partículas não-vitais circundadas por tecido conjuntivo e somente em alguns cortes o enxerto estava em contato com osso do leito receptor. Os alvéolos com osso inorgânico mostraram características semelhantes ao DFDBA, só que apenas em cortes isolados o enxerto estava em contato com osso hospedeiro. Os fragmentos de osso autógeno implantados demonstraram uma combinação de osso não-vital com osso neoformado envolvidos por tecido conjuntivo. A combinação de BMP/NCP no alvéolo indicou grande formação óssea com a presença de osso lamelar e imaturo. Os micro-implantes instalados nos alvéolos com osso autógeno estavam circundados parcialmente por osso vital, enquanto que os micro-implantes instalados nos alvéolos com osso inorgânico e DFDBA não apresentaram evidências de contato com os materiais de enxerto e osso vital. Os resultados permitiram concluir que o osso bovino inorgânico, o DFDBA e o osso autógeno não contribuíram para a reparação do alvéolo dental ou para melhorar a osteointegração dos micro-parafusos de titânio. Entretanto, a combinação de BMP/NCP demonstrou neoformação óssea significativa nos dois alvéolos dentais enxertados.

Froum et al. (2002) analisaram a reparação de alvéolos dentais após a exodontia preenchidos com vidro bioativo e DFDBA. Foram avaliados 30 alvéolos dentais em 19 pacientes divididos igualmente em 3 grupos: controle sem implantação de enxerto, experimental com preenchimento de vidro bioativo e experimental com preenchimento de DFDBA. Decorridos 6 a 8 meses da extração dental, biópsias dos alvéolos foram coletadas para análise histológica previamente à instalação de implantes dentais. Os resultados mostraram um total de osso vital de $59.5 \%$ nos alvéolos com vidro bioativo, $34.7 \%$ nos enxertados com DFDBA e 32.4\% nos alvéolos controle. Entretanto, a análise estatística 
revelou não haver diferenças significativas entre os resultados. Os autores relatam que apesar dos resultados não serem estatisticamente significantes, o vidro bioativo se mostrou um material osteocondutor que tem um efeito positivo na reparação alveolar decorridos 6 a 8 meses depois da extração dental.

\subsection{MARCADORES DE OSSIFICAÇÃO}

A injeção subcutânea ou intramuscular de biomarcadores ósseos permite avaliar a deposição periódica de minerais durante a ossificação. Os marcadores unem-se permanentemente aos cristais de hidroxiapatita em desenvolvimento e com auxílio de um microscópio com luz fluorescente é possível observar o osso neoformado marcado. Boyne e Kruger (1962), Haddad et al. (1965), Boyne (1966), Hsieh et al. (1994), Hsieh et al. (1995), Gauthier et al. (1999), Baptista (2004), Madid (2004) e Tamae (2005) utilizaram marcadores de ossificação no estudo da reparação do alvéolo dental após exodontia. Os marcadores também foram utilizados para avaliar a osteointegração de implantes nos trabalhos de König Júnior et al. (1998), Lugero et al. (2000), Ferreira (2003), Lopes (2003) e Ottoni e Chopard (2004).

\subsection{ENXERTO ÓSSEO AUTÓGENO}

A utilização do osso autógeno como material para enxerto é considerada a melhor para esta finalidade, sendo eleito por muitos como o "padrão ouro" (GROENEVELD, 1999; HOEXTER, 2002; MAZOCK et al., 2004; MINICHETTI et al., 2004; JENSEN et al., 2006). O osso autógeno apresenta potencial de reter células vitais e transportá-las ao leito receptor, tem capacidade de proporcionar osteoindução e osteocondução, não induz reação imunológica e é completamente substituído por osso do leito receptor (BECKER et al., 1998; BECKER, 2003). 
Entretanto, a utilização do osso autógeno como material de enxerto causa uma maior morbidade ao indivíduo, já que é necessário um sítio cirúrgico adicional para a obtenção do enxerto. Além disso, o desconforto pós-operatório do paciente e o risco de infecção do local cirúrgico são aumentados.

A escolha do local doador dependerá da quantidade de volume ósseo necessário para restabelecer o contorno original do processo alveolar reabsorvido. Os possíveis locais para coleta do enxerto envolvem sítios cirúrgicos intraorais ou extraorais. As áreas intraorais mais comumente utilizadas para remoção do enxerto ósseo são as regiões do mento (JENSEN e SINDET-PEDERSEN, 1991; WIDMARK et al., 1997), margem anterior do ramo da mandíbula (LEVIN et al. 2007) e tuberosidade maxilar (BEZERRA e MENDONÇA, 2002). As áreas extraorais utilizadas como doadoras de tecido ósseo englobam a crista ilíaca (LUNDGREN et al., 1999; NKENKE et al. 2004), a calvária (DONOVAN et al.,1994), a tíbia (MAZOCK et al., 2004; PINTO et al., 2004) e as costelas (MALETTA et al., 1983).

Muitas vezes a morbidade do procedimento cirúrgico para remoção do enxerto e a disponibilidade óssea nestes sítios para a coleta é limitada. Os aloenxertos ou biomateriais podem ser utilizados como alternativas de materiais de enxerto, apesar de não suprirem ainda as vantagens do osso autógeno. Todavia, esses materiais apresentam indicações específicas nos procedimentos cirúrgicos de restauração de defeitos ósseos (AICHELMANN-REIDY e YUKNA, 1998; PALECKIS, 2004).

De acordo com Paleckis (2004) o êxito nos procedimentos de enxertia com osso autógeno depende de variáveis relativas ao hospedeiro, à área doadora e à técnica cirúrgica. A forma macroscópica do enxerto é outro fator a ser considerado, já que a decisão pelo uso de osso particulado ou em bloco pode interferir no resultado e no tempo total do tratamento. $\mathrm{O}$ grau e velocidade da revascularização do enxerto ósseo também é um fator importante para o 
sucesso do procedimento. Segundo CARANO e FILVAROFF (2003) a vascularização inadequada do osso é associada à diminuição da formação óssea.

A revascularização depende da angiogênese oriunda do leito receptor. A arquitetura do enxerto (particulado ou em bloco) e o preparo do sítio receptor influenciam na velocidade da revascularização do enxerto, garantindo sua vitalidade (FONSECA et al. 1980; ALBERIUS et al., 1996; CARVALHO et al., 2000; PALECKIS, 2004).

A primeira característica histológica do reparo do enxerto ósseo no leito receptor é o aparecimento de uma resposta inflamatória juntamente com o brotamento de vasos sangüíneos. Em seguida, observa-se a proliferação do tecido de granulação, diminuição da quantidade de células inflamatórias e aumento da atividade de osteoclastos. No interior do enxerto ocorre à autólise dos osteócitos devido à falta de nutrição e pelo trauma ocasionado durante a cirurgia, o que deixa as lacunas no interior da matriz óssea vazias. Algumas células periféricas permanecem vitais pela difusão de nutrientes oriundos dos tecidos moles do leito receptor. A partir dessa etapa o reparo dos enxertos corticais ou medulares difere na velocidade de revascularização e no mecanismo de incorporação e substituição do enxerto. A penetração de vasos sangüíneos no enxerto medular é pelo menos 2 vezes mais rápida que no cortical. No enxerto medular a invasão vascular permite a diferenciação de células mesenquimais primitivas em células osteogênicas, que por sua vez se diferenciam em osteoblastos. Os osteoblastos delimitam o fragmento ósseo não-vital e deposita tecido osteóide ao seu redor. O reparo do enxerto cortical difere do medular, pois primeiramente há um processo de reabsorção óssea promovida por osteoclastos para depois haver uma fase de deposição óssea realizada pelos osteoblastos. O enxerto medular é completamente reparado pela substituição dos fragmentos de osso necrosado por osso novo vital. Ao término da reparação do enxerto cortical nem todas as partículas de osso necrosado são substituídas, observando-se uma mistura de osso vital com osso não-vital (BURCHARDT,1983). 
A obtenção e fixação de enxertos ósseos devem ser realizadas de acordo com as consagradas técnicas cirúrgicas a fim de minimizar injúrias aos tecidos envolvidos e reduzir o risco de infecções. Bezerra e Mendonça (2002) e Hupp (2000) relatam que alterações fisiopatológicas sistêmicas do paciente, como diabetes mellitus, discrasias sangüíneas, deficiências imunológicas, entre outras, também devem ser avaliadas no planejamento, haja vista estas alterações podem alterar a reparação pós-operatória no sítio cirúrgico. 


\section{MATERIAL E MÉTODO}

\subsection{MODELO EXPERIMENTAL}

Para a realização dos experimentos foram utilizados 67 Rattus Norvegicus Albinus, linhagem Wistar, machos, provenientes do Biotério Central do Instituto de Ciências Biomédicas da Universidade de São Paulo. Os animais foram mantidos em condições controladas de temperatura $\left(21^{\circ} \mathrm{C}\right)$ e de iluminação (12 horas de luz / 12 horas de escuro), com ração balanceada ${ }^{1}$ e água a vontade, exceto pela suspensão do alimento sólido e a utilização da mesma ração triturada e umedecida nas primeiras 24 horas após a extração dental.

Dividiram-se os animais em um grupo controle e outro experimental. Os ratos do grupo controle foram submetidos à intervenção cirúrgica para exodontia apenas, enquanto nos ratos do grupo experimental foram realizadas a exodontia e enxertia óssea no alvéolo dental. O enxerto ósseo foi obtido no osso ilíaco dos próprios animais, sendo os mesmos doadores e receptores do osso coletado (enxerto autógeno). Posteriormente à eutanásia dos ratos, análises histológicas dos alvéolos foram realizadas em microscopia de luz convencional e de luz fluorescente.

\subsection{PROTOCOLO CIRÚRGICO}

Depois de completados 60 dias de vida e com massa corpórea variando entre 190 g e $260 \mathrm{~g}$, o procedimento cirúrgico foi realizado nos animais sob anestesia geral pela aplicação intramuscular de cloridrato de 2-(2,6-xilidino)-5,6-dihidro-4H-1,3-tiazina ${ }^{2}$ 0,25 ml/kg, com posterior aplicação também intramuscular de cloridrato de tiletamina e cloridrato de

\footnotetext{
${ }^{1}$ Guabi Nutrilabor - Rato e Camundongo

${ }^{2}$ Rompun - Bayer S.A. - Saúde Animal
} 
zolazepam ${ }^{3} 1 \mathrm{ml} / \mathrm{kg}$. Os princípios de biossegurança foram respeitados a fim de se evitar processos infecciosos nas áreas cirúrgicas, o que poderia comprometer os resultados do experimento.

O acesso ao sítio doador do enxerto ósseo no grupo experimental foi realizado inicialmente pela tricotomia da região dorso-caudal direita do animal, anti-sepsia com PVPI com $1 \%$ de iodo ativo, iodato de potássio e glicerina ${ }^{4}$ da região e ulterior incisão da pele e fáscia muscular com lâmina de bisturi nº 15 (Figura 1).

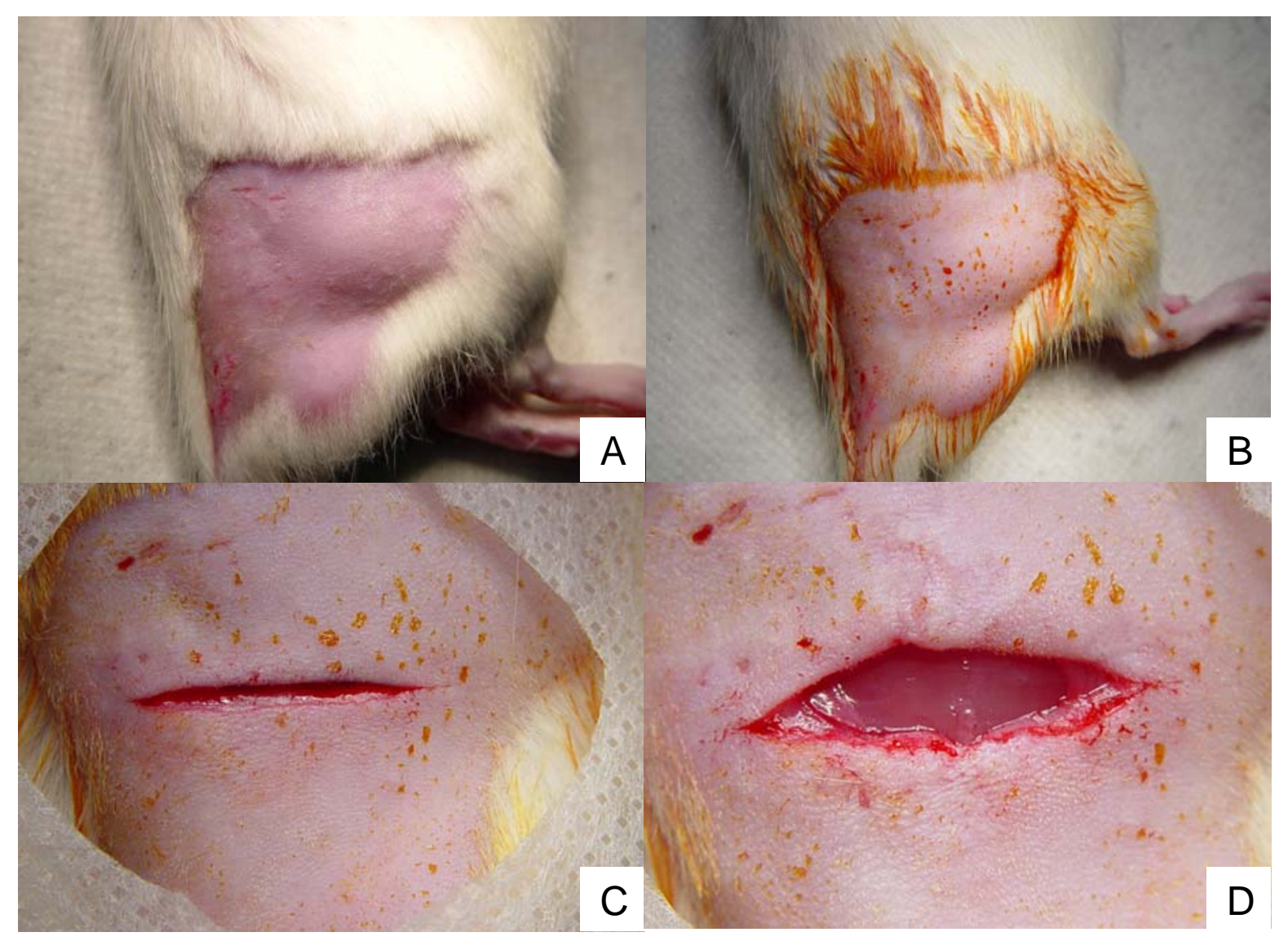

Figura 1 - A) Tricotomia da região dorso-caudal do animal; B) Anti-sepsia do local cirúrgico; C) Incisão da pele; D) Incisão da fáscia muscular.

\footnotetext{
${ }^{3}$ Zoletil 50 - Virbac saúde animale

${ }^{4}$ Povidine - Iodopovidona tópico - Qualiplus indústria e comércio
} 
Em seguida foram divulsionados os tecidos para observação da musculatura que se insere no osso ilíaco do animal. Esta camada muscular foi incisada e rebatida para exposição do osso. Utilizando-se uma pinça goiva foi removido o enxerto ósseo. O osso colhido foi colocado em solução fisiológica estéril e particulado em fragmentos menores para posterior utilização. A fragmentação do enxerto foi realizada por meio do uso de um cinzel biselado utilizado manualmente. $\mathrm{O}$ tamanho médio das partículas ósseas do enxerto era de 0,5 a 1,5 mm. A estimativa das medidas das partículas foi realizada através de um programa de imagens $^{5}$. Os tecidos rebatidos e divulsionados foram reposicionados e a sutura da pele foi realizada com fio de seda 5-0 agulhado $^{6}$ (Figura 2).

\footnotetext{
${ }^{5}$ Image Pro-Plus Versão 4.5

${ }^{6}$ Shalon Fios Cirúrgicos
} 


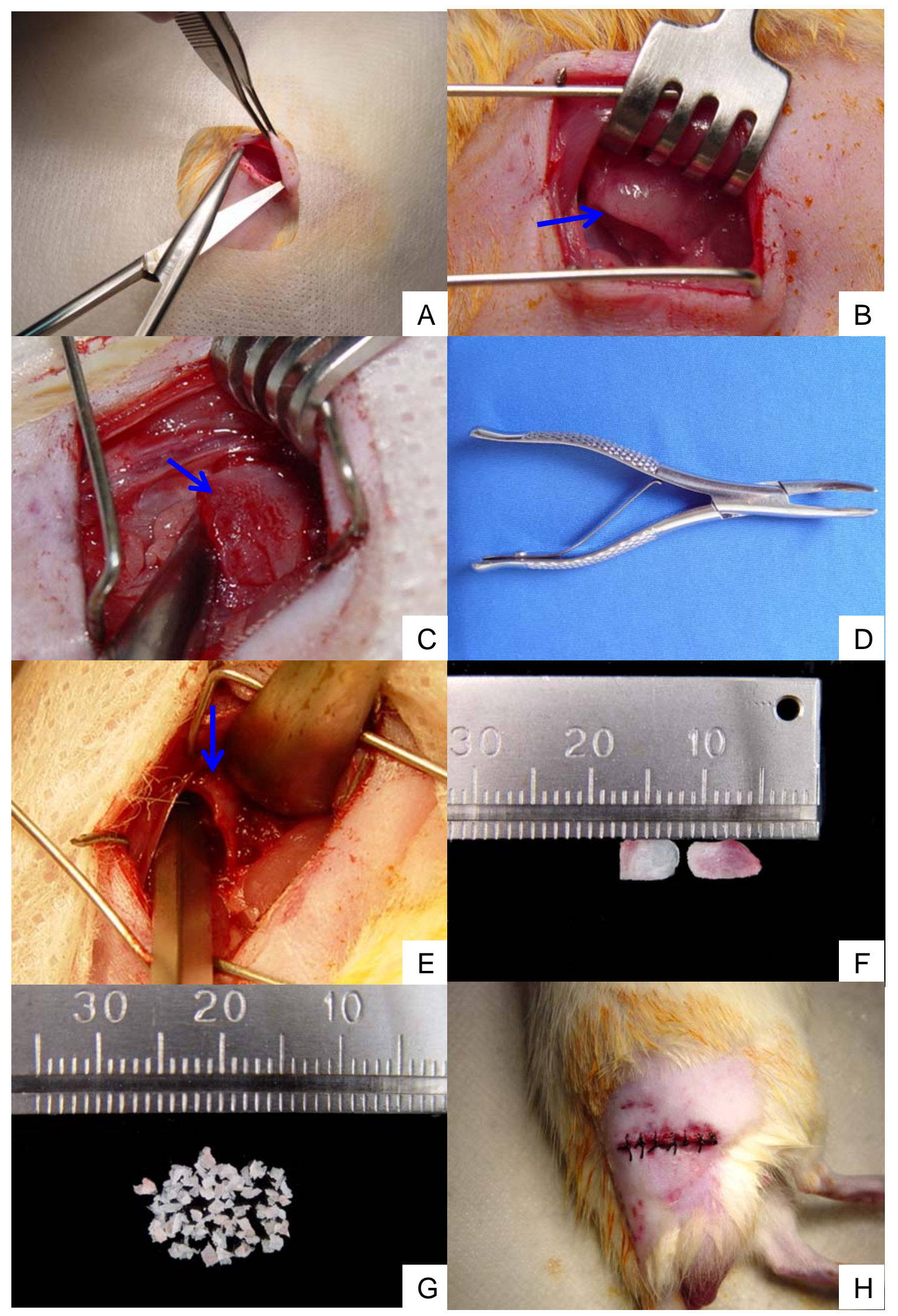

Figura 2 - A) Divulsão dos tecidos; B) Musculatura inserida no osso ilíaco (seta); C) Exposição do osso ilíaco (seta); D) Pinça goiva; E) Osso ilíaco após a remoção do enxerto (seta); F e G) Enxerto ósseo coletado e triturado; H) Sutura da pele. 
A figura 3 a seguir mostra a anatomia do osso do quadril do rato Wistar e a região em que o enxerto é removido.

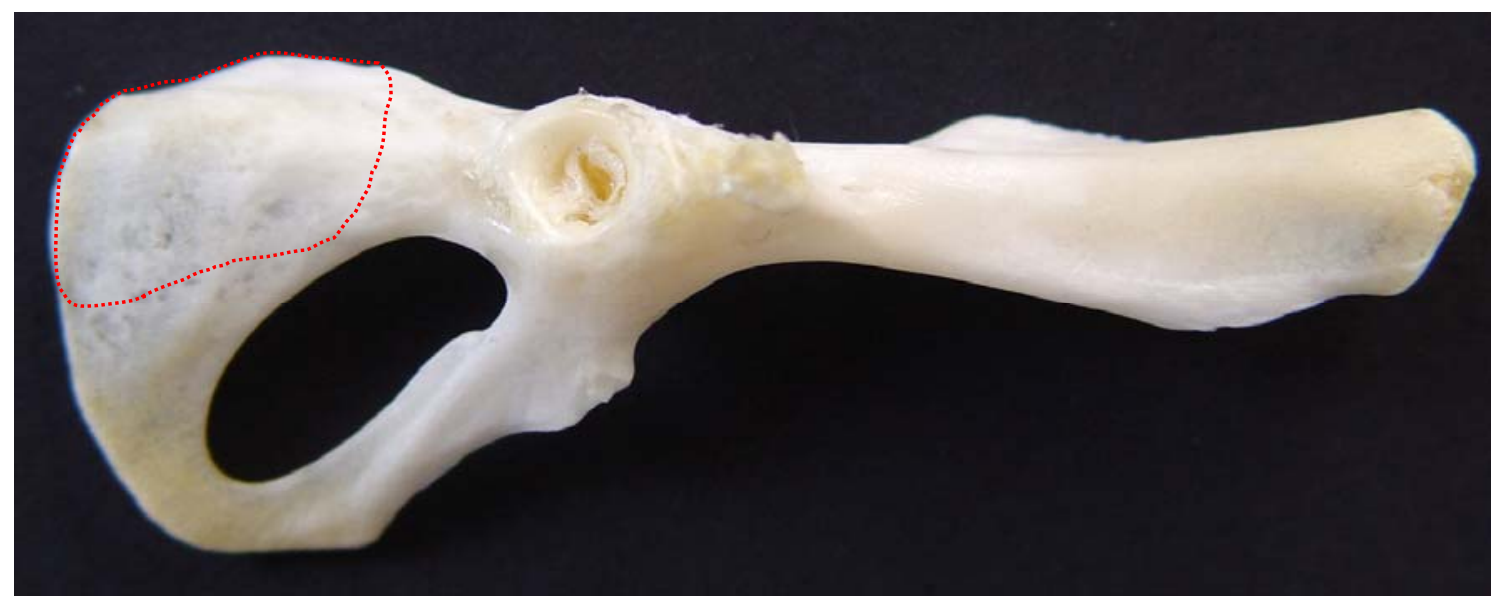

Figura 3 - Anatomia do osso do quadril do rato Wistar. O tracejado em vermelho indica a região em que o enxerto ósseo é coletado.

Terminada a coleta do enxerto ósseo, os animais foram submetidos à exodontia do incisivo superior direito com instrumentos apropriados após anti-sepsia prévia da região com PVPI com $1 \%$ de iodo ativo, iodato de potássio e glicerina ${ }^{4}$. Os instrumentos utilizados foram: um esculpidor Hollenback 3SS para sindesmotomia da gengiva marginal e luxação do dente no sentido médio-distal, um machado para esmalte dental $n^{\circ} 79$ para luxação do dente no sentido palato-vestibular e um fórceps infantil n 1 para avulsão do dente (Figura 4).

Após a exodontia, os ratos do grupo experimental tiveram seus alvéolos preenchidos com o osso autógeno particulado previamente coletado. A acomodação do enxerto no interior do alvéolo foi realizada com um condensador de amálgama $n^{\circ} 1$. Em seguida foi feita a sutura dos tecidos moles com fio de seda 5-0 agulhado ${ }^{6}$ respeitando o periósteo. No grupo controle a sutura foi realizada logo depois da exodontia sem que o alvéolo fosse preenchido com osso (Figura 4).

Utilizando-se uma balança digital, a aferição da massa corpórea dos animais foi realizada no dia da cirurgia, em períodos pós-operatórios específicos e no dia da eutanásia dos ratos. 


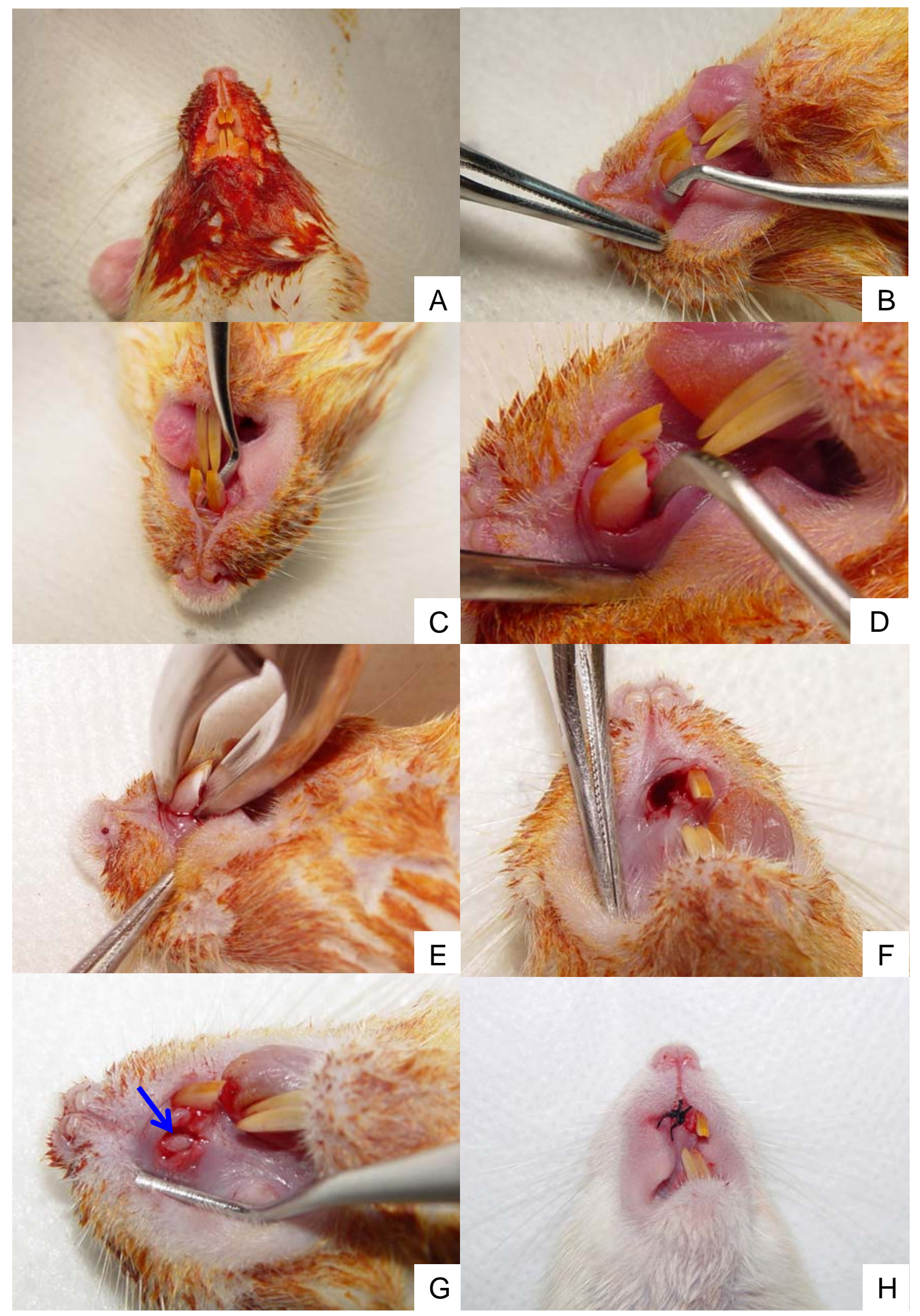

Figura 4 - A) Anti-sepsia da região perioral; B) Sindesmotomia; C) Luxação do dente no sentido médio-distal; D) Luxação do dente no sentido palato-vestibular; E) Apreensão do dente com fórceps; F) Alvéolo dental após a exodontia; G) Alvéolo dental preenchido com enxerto ósseo. A seta indica o fragmento de enxerto; H) Sutura oclusiva dos tecidos moles. 


\subsection{MEDICAÇÃO PÓS-OPERATÓRIA}

Todos os animais receberam medicação ao término da cirurgia e depois de 1 dia de pós-operatório. Foram aplicados o antiinflamatório e analgésico flunixin ${ }^{7}$ ministrado via subcutânea na dosagem de $0,2 \mathrm{ml} / \mathrm{kg}$ e um antibiótico composto pela associação de benzilpenicilina benzatina, benzilpenicilina procaína, benzilpenicilina potássica, diidroestreptomicina base (sulfato) e estreptomicina base (sulfato) ${ }^{8}$ na dosagem de $1 \mathrm{ml} / \mathrm{kg}$ ministrado por via intramuscular.

\subsection{APLICAÇÃO DE MARCADOR DE OSSIFICAÇÃO}

Ao atingir o sétimo, décimo quarto e vigésimo primeiro dias de pós-operatório, todos os ratos destinados à análise em microscopia de luz fluorescente receberam aplicações subcutânea do marcador de ossificação calceína ${ }^{9}$ na dosagem de $10 \mathrm{mg} / \mathrm{kg}$ dissolvido em solução de bicarbonato de sódio $2 \%$. A quantidade da solução a ser misturada com o marcador foi na proporção de $1 \mathrm{ml} / \mathrm{kg}$ do animal.

\subsection{PROTOCOLO DE EUTANÁSIA}

Em tempos pós-operatórios específicos $(5,15,21$ e 28 dias) a eutanásia dos animais foi realizada por decapitação. A eutanásia dos ratos que receberam injeção subcutânea do marcador de ossificação calceína foi efetuada no $28^{\circ}$ dia de pós-operatório. Depois da eutanásia, foram dissecadas, removidas e reduzidas as partes ósseas que contêm o alvéolo dental de cada maxila direita (Figura 5). Alvéolos que apresentaram sinais de infecção foram descartados.

\footnotetext{
${ }^{7}$ Banamine injetável 10mg - Schering Plough Veterinária

${ }^{8}$ Pentabiótico veterinário pequeno porte - Fort Dodge

${ }^{9}$ Calceína PA - Vetec Química Fina
} 


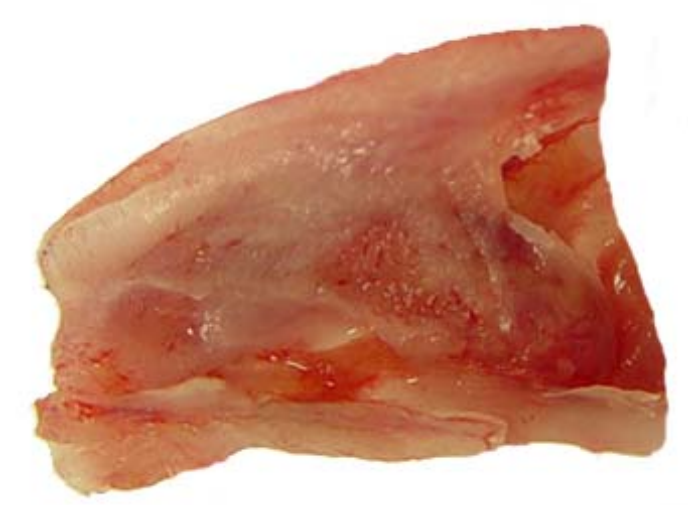

Figura 5 - Partes ósseas da maxila direita que contêm o alvéolo dental

\subsection{PREPARO PARA MICROSCOPIA DE LUZ FLUORESCENTE}

As maxilas dos animais que receberam calceína foram imersas imediatamente em solução fixadora de formaldeído tamponado com PBS (phosphate buffer solution) permanecendo por um período de 24 horas. Depois de fixadas, as peças foram lavadas em água corrente por um período de 12 horas. Posteriormente foram desidratadas em álcool $70^{\circ}$ por 24 horas e em três soluções de álcool $100^{\circ}$, sendo que na primeira permaneceram por 24 horas, na segunda por 48 horas e na terceira por 56 horas. As peças foram então diafanizadas em xilol por 24 horas, sendo trocada a solução e permanecendo por mais 48 horas.

Completados os procedimentos de fixação, desidratação e diafanização, as peças foram incluídas em resina formulada com Diisobutilftalato ${ }^{10}$, Metilmetacrilato ${ }^{11}$ e Peróxido de Benzoíla $^{12}$. Inicialmente foi preparada $100 \mathrm{ml}$ de solução composta por $15 \mathrm{ml}$ de Diisobutilftalato e $85 \mathrm{ml}$ de Metilmetacrilato. A solução foi dividida em recipientes de vidro com tampa e capacidade volumétrica de aproximadamente $20 \mathrm{ml}$ onde se encontrava cada amostra. As maxilas com o alvéolo dental permaneceram imersas na solução por 7 dias, sendo estocadas em geladeira a fim de evitar a polimerização da resina. Ao término desse período, as peças foram mergulhadas por mais 7 dias em solução composta por $15 \mathrm{ml}$ de Diisobutilftalato, $85 \mathrm{ml}$ de Metilmetacrilato e $1 \mathrm{~g}$ de Peróxido de Benzoíla, continuando

\footnotetext{
${ }^{10}$ Diisobutyl phthalate 99\% - Sigma - Aldrich Chemie

${ }^{11}$ Methyl methacrilate $99 \%$ - Fluka Chemie

${ }^{12}$ Benzoyl peroxide - Fluka Chemie
} 
estocadas em geladeira. Ulteriormente as amostras foram mergulhadas em solução composta por $15 \mathrm{ml}$ de Diisobutilftalato, $85 \mathrm{ml}$ de Metilmetacrilato e $5 \mathrm{~g}$ de Peróxido de Benzoíla, permanecendo em temperatura ambiente até a completa polimerização da resina. Concluída a polimerização, os recipientes de vidro foram quebrados e os blocos de resina obtidos foram reduzidos somente à parte ocupada pela maxila contendo o alvéolo (Figura 6).

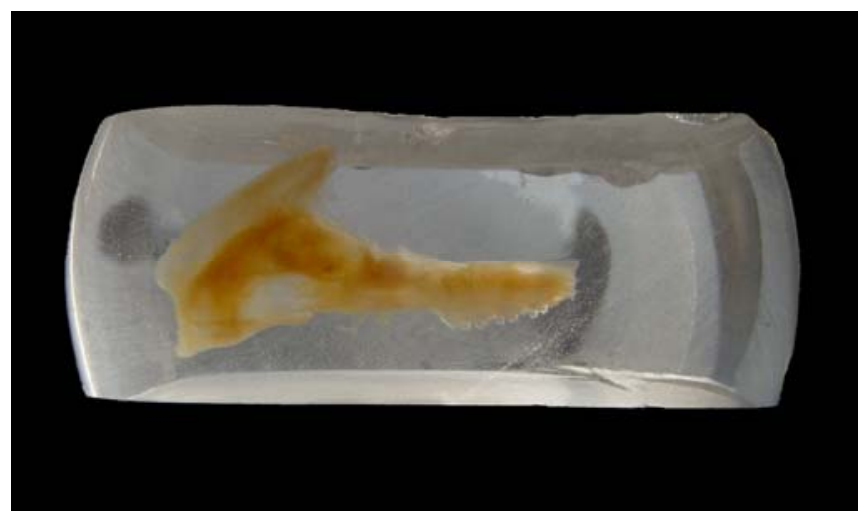

Figura 6 - Inclusão em resina da maxila com o alvéolo dental

Em seguida, secções transversas ao longo eixo do terço médio do alvéolo dental foram realizadas por meio de uma fita diamantada refrigerada por água, instalada em equipamento específico $^{13}$. Três cortes de cada amostra foram fixados com éster de cianoacrilato ${ }^{14}$ em lâminas de acrílico incolor transparente. Finalizada essa etapa, os cortes foram afinados e polidos por meio de lixas abrasivas nas granulações de 1000, 2500 e 4000 montadas em politriz para preparação de amostras metalográficas ${ }^{15}$ (Figura 7). Concluídos estes procedimentos, as lâminas foram analisadas em microscopia de luz fluorescente.

\footnotetext{
${ }^{13}$ Exakt Ban System 300 CP - EXAKT Apparatebau GmbH \& Co., Kg of Norderstedt, Germany - Laboratório de Tecidos Mineralizados do Departamento de Anatomia ICB - USP

${ }^{14}$ Super Bonder - Loctite - Henkel Ltda.

15 Modelo DP-10 Struers, Panambra Industrial e Técnica S.A. - Laboratório de Tecidos Mineralizados do Departamento de Anatomia ICB - USP
} 


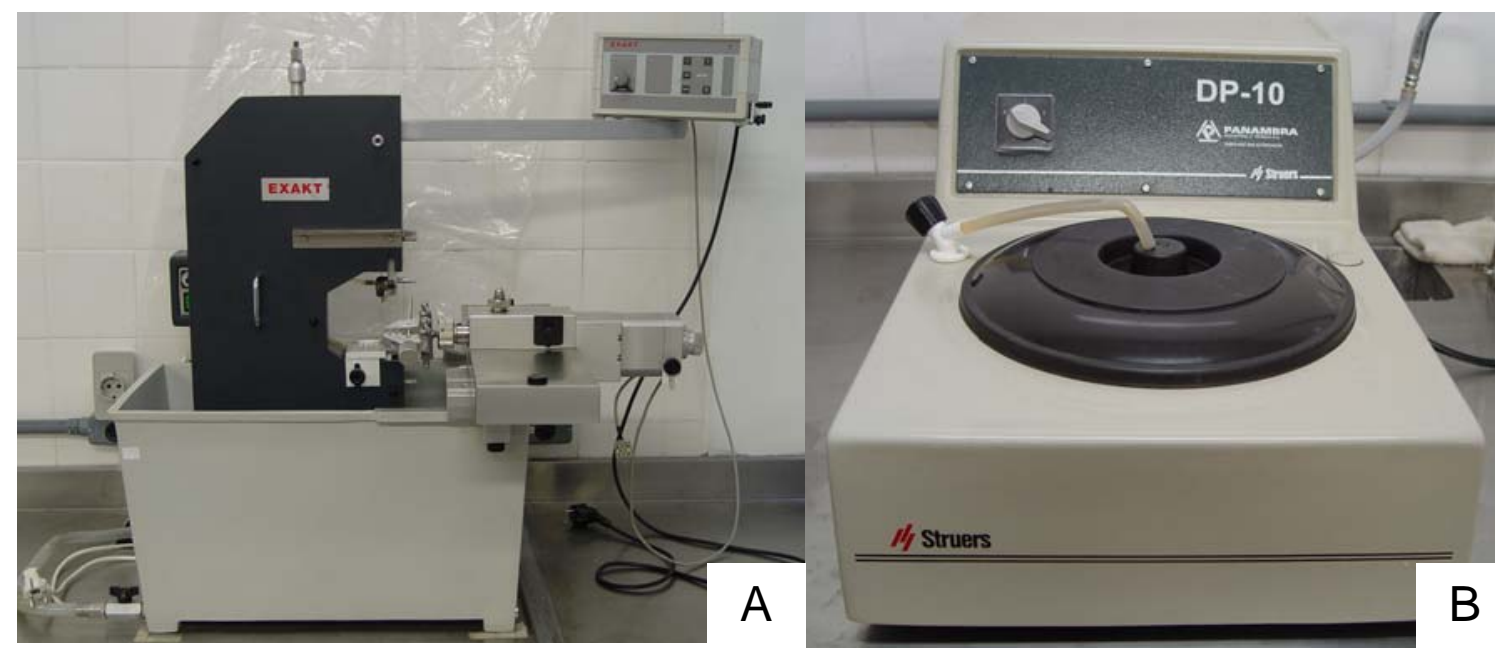

Figura 7 - A) Exakt Band System 300 CP; B) Politriz metalográfica modelo DP-

\subsection{PREPARO PARA MICROSCOPIA DE LUZ CONVENCIONAL}

As maxilas removidas com e sem enxerto foram fixadas em solução de formaldeído tamponado com PBS e permaneceram imersas por um período de 24 horas. Depois de fixadas, as peças foram lavadas em água corrente por um período de 12 horas e em seguida mergulhadas em solução de EDTA 5,5\% com pH 7,4 para descalcificação. A solução de EDTA era trocada a cada dois dias a fim de se evitar a saturação da solução. Aproximadamente após duas semanas as amostras estavam descalcificadas. Concluída essa etapa, as peças foram lavadas novamente em água corrente por um período de 12 horas e logo mergulhadas em álcool $70^{\circ}$.

Posteriormente, as peças imersas em álcool $70^{\circ}$ foram desidratadas em álcool $95^{\circ}$ por 1 hora, em seguida por álcool $100^{\circ}$ por 1 hora, sendo trocada a solução e permanecendo por mais 2 horas. Concluída a desidratação, as amostras foram diafanizadas em xilol por 30 minutos e mergulhadas em novo xilol por mais 30 minutos.

Depois da diafanização, as peças foram divididas em três partes correspondentes aos terços cervical, médio e apical do alvéolo dental. O terço médio foi incluído em parafina histológica para que cortes transversos ao seu longo eixo de $5 \mu \mathrm{m}$ de espessura pudessem ser realizados. Seis a dez cortes de cada amostra, com intervalo de $50 \mu \mathrm{m}$ entre si, foram 
montados em lâminas de vidro para serem preparados e então corados com solução de hematoxilina e eosina de Harris e Picro-sírius para análise em microscópio de luz convencional.

\subsection{ANÁLISE QUANTITATIVA DA DENSIDADE DE ÁREA OCUPADA POR OSSO}

Os cortes histológicos dos alvéolos dentais dos ratos que receberam calceína foram observados no microscópio ${ }^{16}$ sob luz fluorescente por meio de objetiva com aumento de $2 \mathrm{x}$. As imagens foram capturadas por uma câmera fotográfica digital ${ }^{17}$ acoplada ao microscópio e analisadas em um programa de imagens ${ }^{18}$ instalado em computador (Figura 8). Este programa permite selecionar a matiz de cor produzida pelo marcador de ossificação calceína na imagem histológica. Depois de selecionada a cor, a determinação em $\mu \mathrm{m}^{2}$ da soma da área ocupada pelo osso depositado periodicamente no alvéolo dental após exodontia foi verificada com outra ferramenta disponível no programa (Figura 9).

\footnotetext{
${ }^{16}$ Nikon Eclipse E 1000 - Laboratório de Neurociências do Departamento de Anatomia ICB - USP

${ }^{17}$ Nikon digital camera DXM 1200F - Laboratório de Neurociências do Departamento de Anatomia ICB - USP

${ }^{18}$ Image Pro-Plus Versão 4.5
} 


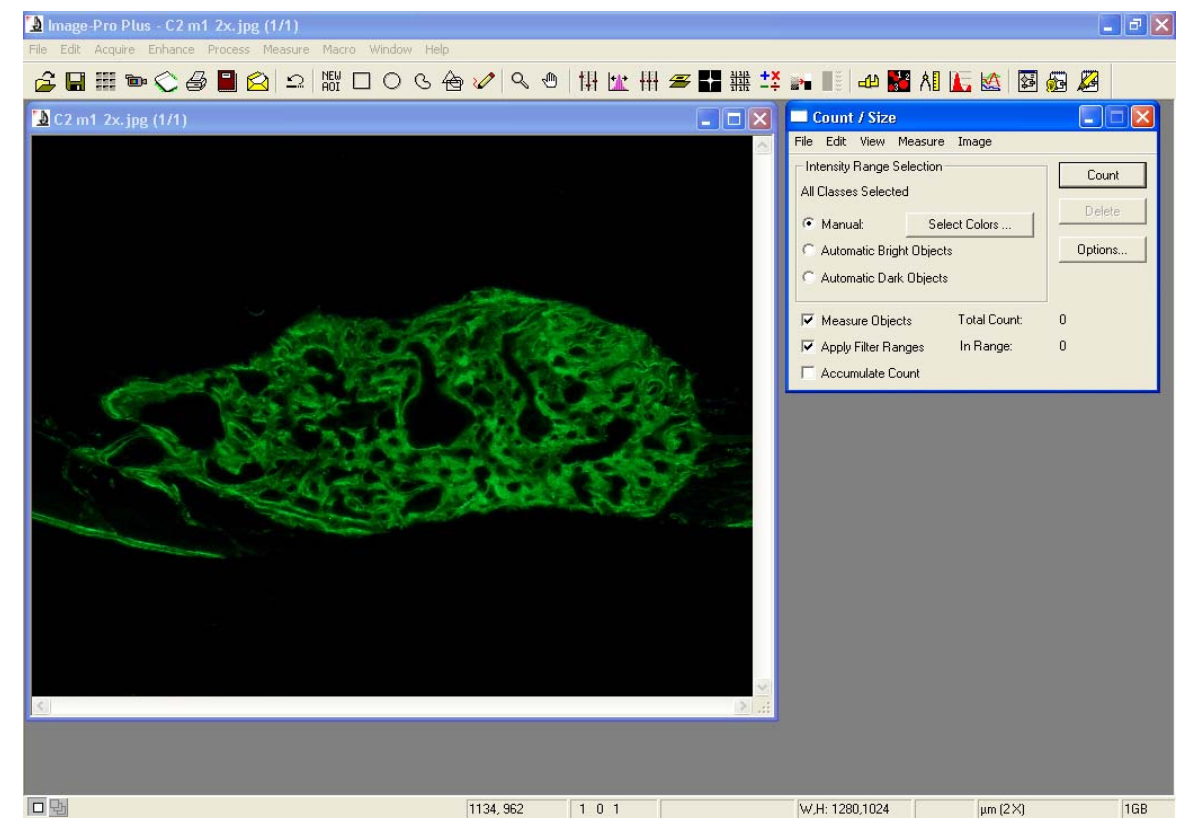

Figura 8 - Observação no programa de imagens do corte histológico do alvéolo dental de um rato injetado com calceína.

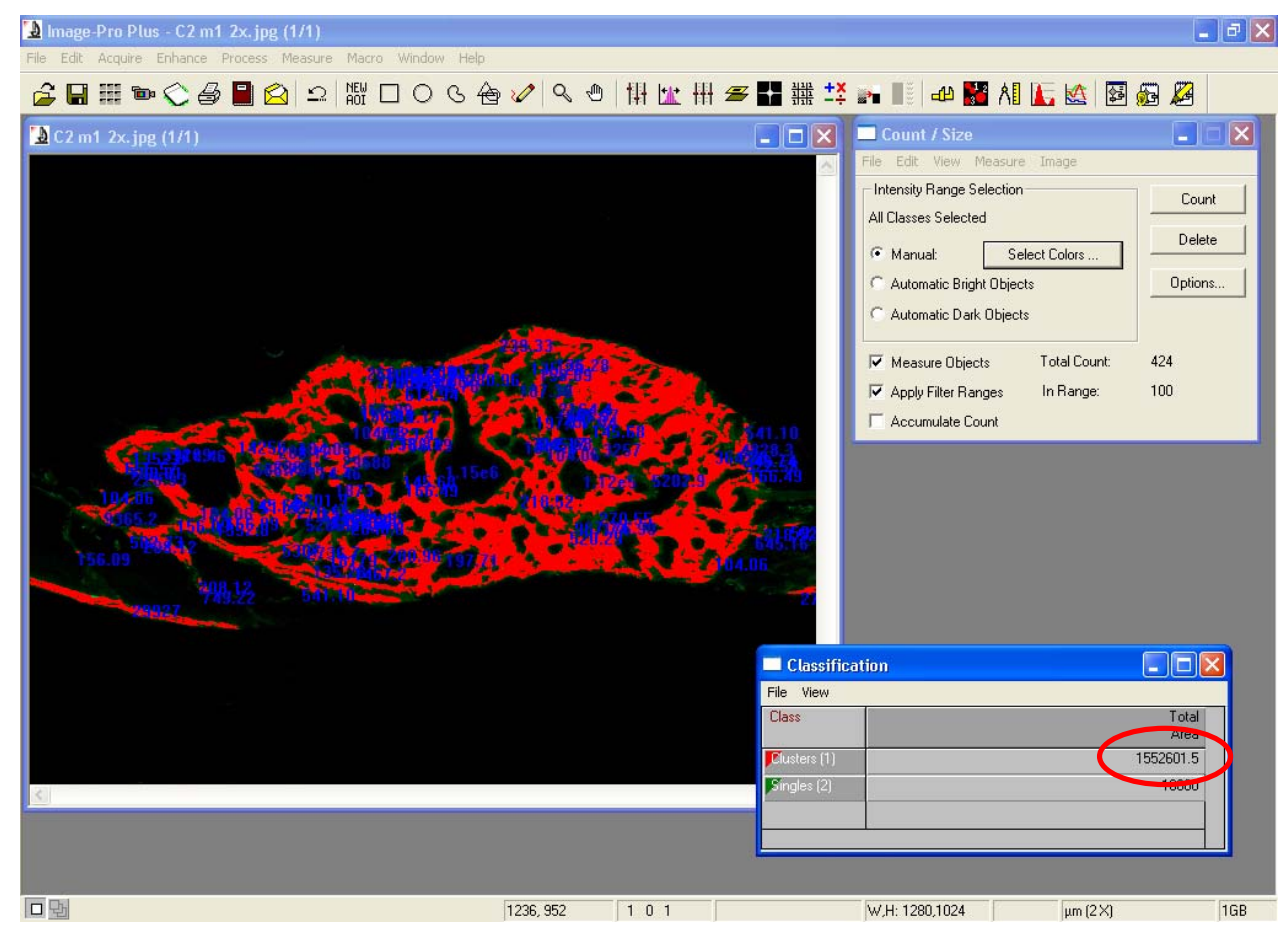

Figura 9 - Seleção da cor produzida pela calceína e determinação da soma da área ocupada por osso depositado periodicamente. A elipse vermelha destaca o resultado da soma encontrada em $\mu \mathrm{m}^{2}$.

Os cortes histológicos dos alvéolos dos ratos que não receberam calceína, corados com hematoxilina e eosina de Harris, foram observados em microscópio ${ }^{16}$ sob luz convencional 
através de objetiva com aumento de $4 \mathrm{x}$. As imagens foram capturadas por uma câmera fotográfica digital ${ }^{17}$ acoplada ao microscópio. A análise morfométrica dos cortes histológicos foi realizada pela determinação da densidade da área ocupada por tecido ósseo no alvéolo dental encontrada nos diversos dias de pós-operatório. Esta área foi representada pelas corticais ósseas do alvéolo e osso neoformado.

A densidade da área foi estimada por um método de contagem diferencial de pontos através de sistema teste (Figura 10), onde foram contados no alvéolo dental os pontos que incidiram em tecido ósseo e os que incidiram fora de tecido ósseo. A imagem capturada dos cortes histológicos foi observada no programa de computador Microsoft Office Picture Manager ${ }^{\circledR}$ e o sistema teste foi sobreposto ao monitor de 15 polegadas para início da contagem. O sistema teste adotado apresentava 315 pontos dispostos em forma de quadrados, com espaçamento de 1,2 cm entre cada ponto, impresso em folha transparente tamanho A4 e com dimensões de 23,9x18 cm.

\begin{tabular}{|ccccccccccccc}
+ & + & + & + & + & + & + & + & + & + & + \\
+ & + & + & + & + & + & + & + & + & + & + \\
+ & + & + & + & + & + & + & + & + & + & + \\
+ & + & + & + & + & + & + & + & + & + & + \\
& & & & & & & & & & \\
+ & + & + & + & + & + & + & + & + & + & + \\
& & & & & & & & & & \\
+ & + & + & + & + & + & + & + & + & + & + \\
+ & + & + & + & + & + & + & + & + & + & + \\
+ & + & + & + & + & + & + & + & + & + & + \\
\hline
\end{tabular}

Figura 10 - Sistema teste representativo do utilizado originalmente no presente trabalho. 
No mínimo três cortes histológicos de cada alvéolo dental foram analisados. Em cada corte foram capturados digitalmente 2 campos que corresponderam a toda a extensão do corte analisado (Figura 11).

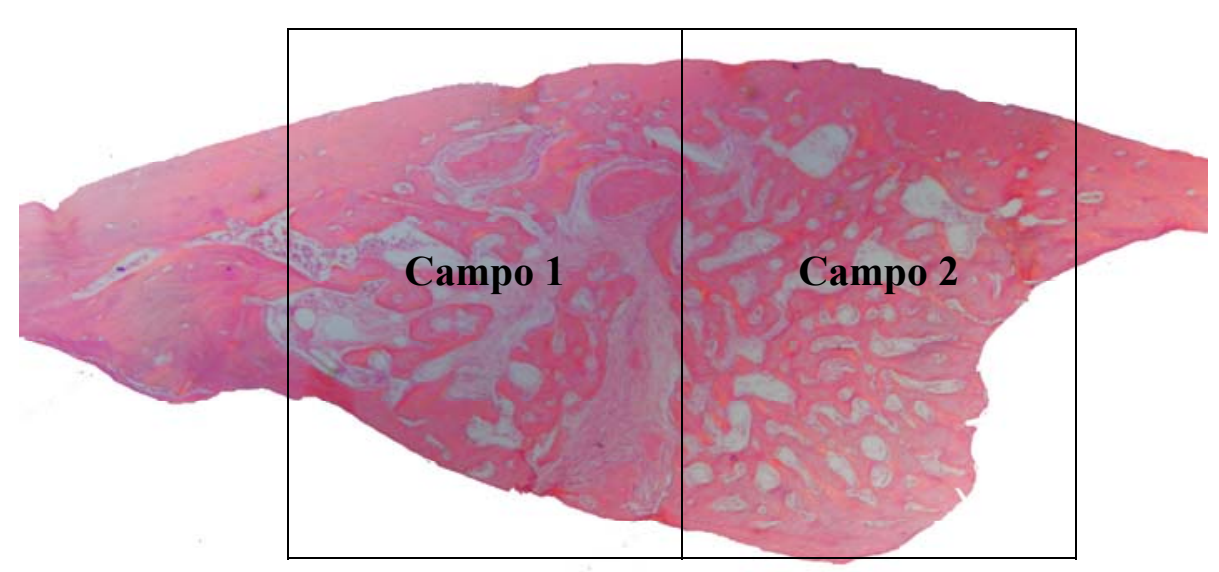

Figura 11 - Representação de um corte histológico corado com hematoxilina e eosina de Harris e os respectivos campos selecionados para morfometria.

Depois de contados os pontos dos campos, somou-se o resultado a fim determinar o número total de pontos que incidiram em osso e fora do osso. Estimou-se a porcentagem da área ocupada por tecido ósseo no alvéolo utilizando a seguinte fórmula matemática:

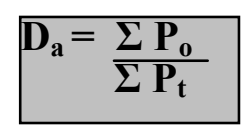

$$
\begin{aligned}
& \mathrm{D}_{\mathrm{a}}=\text { densidade de área. } \\
& \mathrm{P}_{\mathrm{o}}=\text { pontos em osso. } \\
& \mathrm{P}_{\mathrm{t}}=\text { pontos total. }
\end{aligned}
$$

A média das densidades de área encontrada nos cortes analisados foi realizada, obtendo-se a densidade de área ocupada por osso no alvéolo dental de cada animal. A fim de facilitar a compreensão da morfometria realizada, vamos considerar o seguinte exemplo:

\begin{tabular}{|cccccc|}
\hline Rato 1 & $\begin{array}{c}\text { Controle - 21 dias } \\
\text { de pós-operatório }\end{array}$ & Campo 1 & Campo 2 & $\begin{array}{c}\text { Total de pontos } \\
\text { no corte }\end{array}$ & $\begin{array}{c}\text { Densidade } \\
\text { de área }\end{array}$ \\
\hline \multirow{2}{*}{ Corte 1 } & Pontos em osso & 100 & 95 & 195 & \\
& Pontos fora de osso & 65 & 66 & 131 & $\mathbf{0 , 5 9 8 2}$ \\
& Soma dos pontos em & 165 & 161 & 326 & \\
& osso e fora de osso & & & & \\
\hline
\end{tabular}




\begin{tabular}{|cccccc|}
\hline Corte 2 & Pontos em osso & 87 & 89 & 176 & \\
& Pontos fora de osso & 67 & 62 & 129 & $\mathbf{0 , 5 7 7 0}$ \\
& Soma dos pontos em & 154 & 151 & 305 & \\
& osso e fora de osso & & & & \\
\hline \multirow{2}{*}{ Corte 3 } & Pontos em osso & 89 & 66 & 155 & $\mathbf{0 , 5 6 7 8}$ \\
& Pontos fora de osso & 62 & 56 & 118 & \\
& Soma dos pontos em & 151 & 122 & 273 & $\mathbf{0 , 5 7 1 4}$ \\
& osso e fora de osso & & & 144 & \\
Corte 4 & Pontos em osso & 76 & 68 & 108 & \\
& Pontos fora de osso & 50 & 58 & 252 & \\
& Soma dos pontos em & 126 & 126 & & \\
& osso e fora de osso & & & & \\
\hline
\end{tabular}

MÉDIA DAS DENSIDADES DE ÁREA = 0,5786

Nesse exemplo, a média das densidades de área ocupada por osso no alvéolo do animal foi de aproximadamente $58 \%$.

\subsection{ANÁLISE ESTATÍSTICA}

Os resultados obtidos foram submetidos a teste estatístico para análise de variância com dois fatores: tipo de tratamento (grupos controle e experimental) e tempo pós-operatório (5, 15, 21 e 28 dias). Em seguida, comparações múltiplas foram realizadas pelo método de Tukey. O teste "t" de Student foi utilizado para comparação entre os animais dos grupos controle e experimental que receberam calceína. Os resultados da mensuração da massa corpórea dos animais foram verificados pela análise de variância com medidas repetidas. $\mathrm{O}$ nível de significância considerado em todas as análises foi de $\mathrm{p}=0,05$. 


\section{RESULTADOS}

\subsection{MODELO EXPERIMENTAL}

A quantidade de animais utilizados nos períodos pós-operatórios dos grupos controle e experimental pode ser observada a seguir:

\section{GRUPO}

Controle - 5 dias de pós-operatório.

Controle - 15 dias de pós-operatório.

Controle - 21 dias de pós-operatório.

Controle - 28 dias de pós-operatório.

Controle Calceína - 28 dias de pós-operatório.

Experimental - 5 dias de pós-operatório.

Experimental - 15 dias de pós-operatório.

Experimental - 21 dias de pós-operatório.

Experimental - 28 dias de pós-operatório.

Experimental Calceína - 28 dias de pós-operatório.

\section{NÚMERO DE ANIMAIS}

5

5

5

8

6

6

7

8

9

8

67

\subsection{MASSA CORPÓREA DOS ANIMAIS}

A massa corpórea dos animais que foram submetidos à eutanásia no $5^{\circ}$ e $15^{\circ}$ dia de pós-operatório (PO) foi aferida nos seguintes dias:

$\begin{array}{ccccc}\text { Grupos } & \text { Dia da cirurgia } & \mathbf{5}^{\mathbf{0}} \text { dia PO } & \mathbf{1 0}^{\mathbf{0}} \text { dia PO } & \mathbf{1 5}^{\mathbf{0}} \text { dia PO } \\ 5 \text { dias PO } & \mathrm{X} & \mathrm{X} & & \\ 15 \text { dias PO } & \mathrm{X} & \mathrm{X} & \mathrm{X} & \mathrm{X}\end{array}$

A figura 12 mostra a média da massa corpórea dos animais controles e experimentais no dia da cirurgia e após 5, 10 e 15 dias de pós-operatório. 


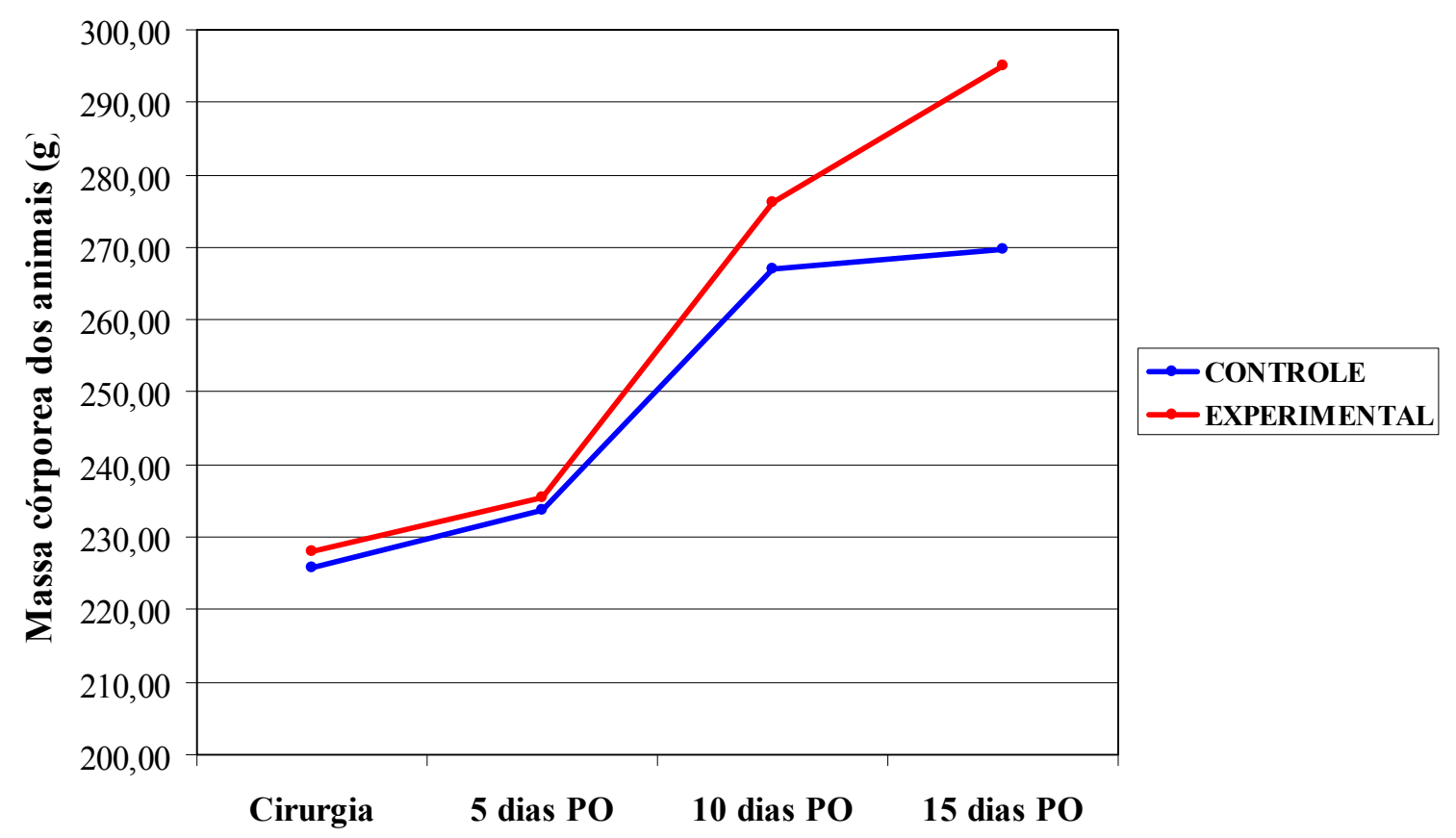

Figura 12 - Média da massa corpórea dos animais dos grupos controle e experimental no dia da cirurgia e após 5, 10 e 15 dias de pós-operatório.

Em ambos os grupos não foi verificado um aumento de massa estatisticamente significante entre o dia da cirurgia e o $5^{\circ}$ dia pós-operatório. A partir do $5^{\circ}$ dia nota-se um aumento progressivo significativo da massa corpórea dos animais dos dois grupos no decorrer dos dias de pós-operatório. Entretanto, não houve diferença significativa no ganho de massa dos animais controle entre o $10^{\circ}$ e o $15^{\circ}$ dias de pós-operatório. Somente no $15^{\circ}$ dia de pósoperatório houve diferença estatística significante entre a média da massa corpórea dos animais dos grupos controle e experimental.

A mensuração da massa corpórea dos animais que foram submetidos à eutanásia no $21^{\circ}$ e $28^{\circ}$ dia de pós-operatório (PO) foi realizada conforme assinalado adiante:

$\begin{array}{cccccc}\text { Grupos } & \text { Dia da cirurgia } & \mathbf{7}^{\mathbf{0}} \text { dia PO } & \mathbf{1 4}^{\mathbf{0}} \mathbf{d i a} \text { PO } & \mathbf{2 1}^{\mathbf{0}} \mathbf{d i a} \mathbf{P O} & \mathbf{2 8}^{\mathbf{0}} \text { dia PO } \\ 21 \text { dias PO } & \mathrm{X} & \mathrm{X} & \mathrm{X} & \mathrm{X} & \\ 28 \text { dias PO } & \mathrm{X} & \mathrm{X} & \mathrm{X} & \mathrm{X} & \mathrm{X}\end{array}$


A média da massa corpórea dos animais controles e experimentais no dia da cirurgia e após 7, 14, 21 e 28 dias de pós-operatório pode ser observada na figura 13.

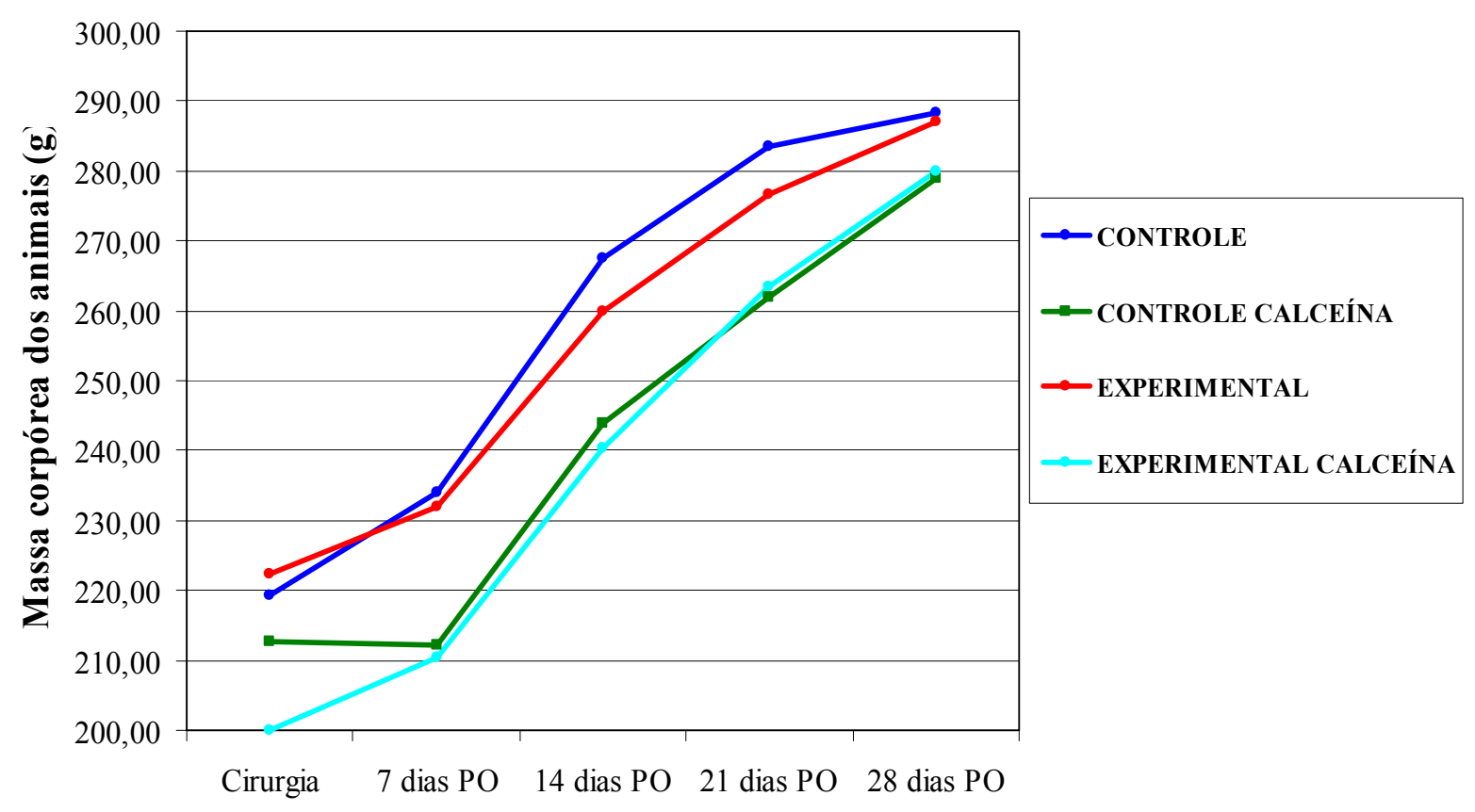

Figura 13 - Média da massa corpórea dos animais dos grupos controle e experimental no dia da cirurgia e após 7, 14, 21 e 28 dias de pós-operatório.

Os resultados demonstraram um ganho de massa corpórea progressivo estatisticamente significativo dos animais durante todo período pós-operatório em todos os grupos. Exceção se faz ao aumento de massa dos ratos controles e experimentais que receberam calceína na primeira semana pós-cirúrgica. Nesse período de tempo não se constatou elevação significativa da massa corpórea dos animais. Comparando-se a média da massa dos animais controle e experimental foi possível verificar que não houve diferença significativa entre todos os tempos pós-operatórios. 


\subsection{ANÁLISE QUALITATIVA DOS CORTES HISTOLÓGICOS CORADOS COM HEMATOXILINA E EOSINA DE HARRIS OBSERVADOS EM MICROSCÓPIO SOB LUZ CONVENCIONAL}

\subsubsection{Grupo controle}

\section{5 dias de pós-operatório}

Os alvéolos dentais dos animais apresentaram remanescente do coágulo sangüíneo principalmente na parte central do alvéolo (Figura 14). Nas áreas mais próximas das corticais ósseas nota-se proliferação de fibroblastos, atividade osteoclástica e ainda formação de trabéculas ósseas delgadas, desorganizadas e circundadas por osteoblastos. Células inflamatórias também são identificadas em toda extensão do corte do alvéolo, assim como diversos vasos sangüíneos (Figuras 15 e 16).

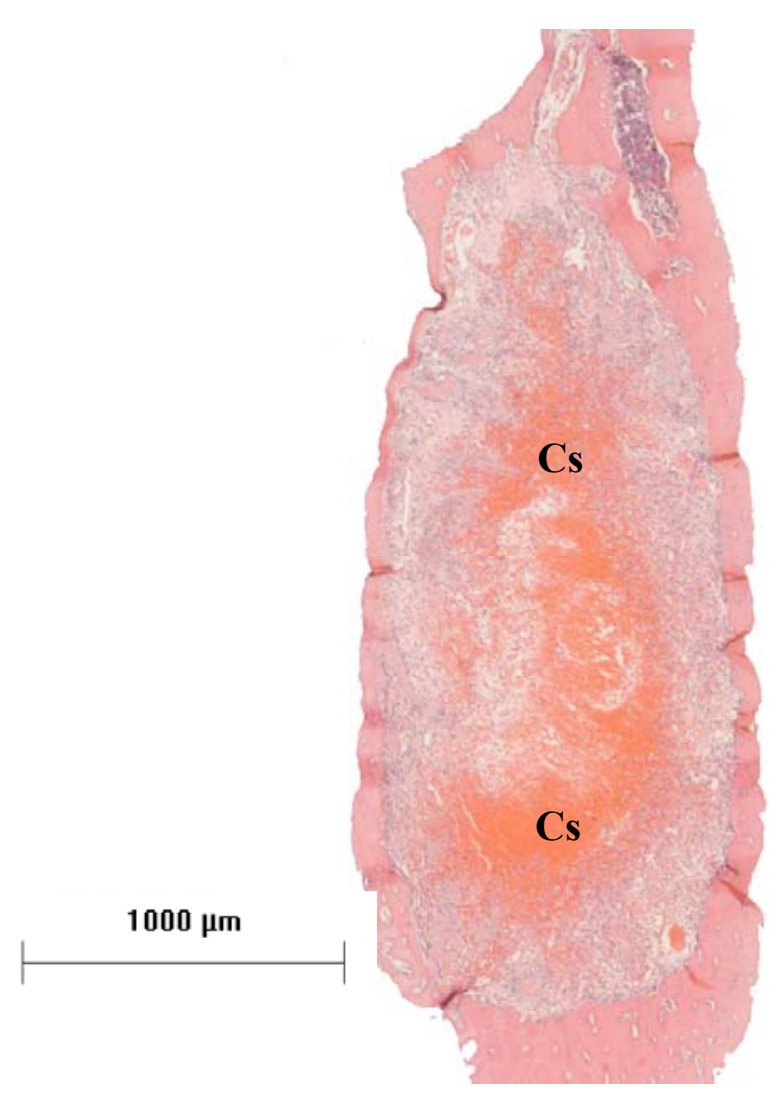

Figura 14 - Controle 5 dias de pós-operatório. Observa-se remanescente do coágulo sangüíneo na parte central do alvéolo (Cs). Objetiva de 2x. 


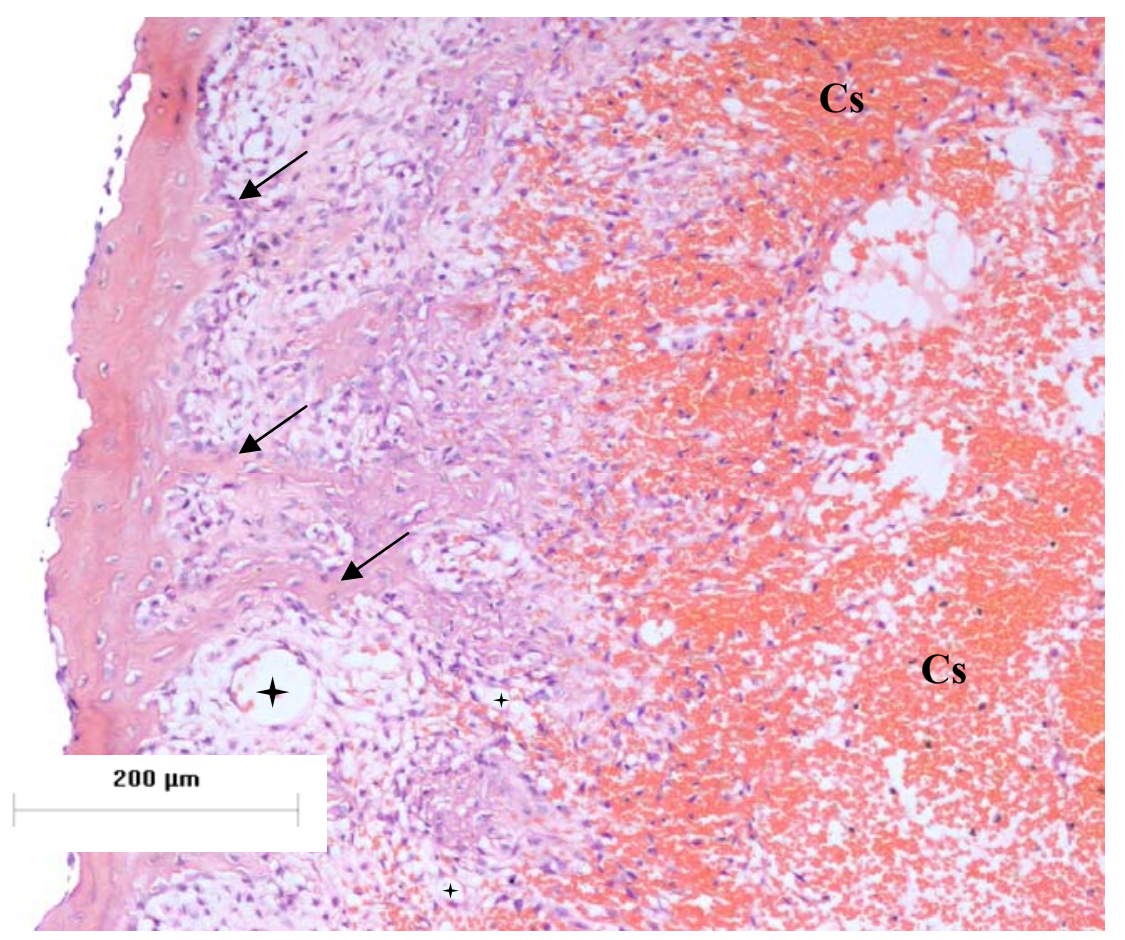

Figura 15 - Controle 5 dias de pós-operatório. Nota-se remanescente do coágulo sangüíneo na parte central do alvéolo (Cs), formação de trabéculas ósseas delgadas e presença de vasos sangüíneos $\left(^{+}\right)$. Objetiva de 10x.

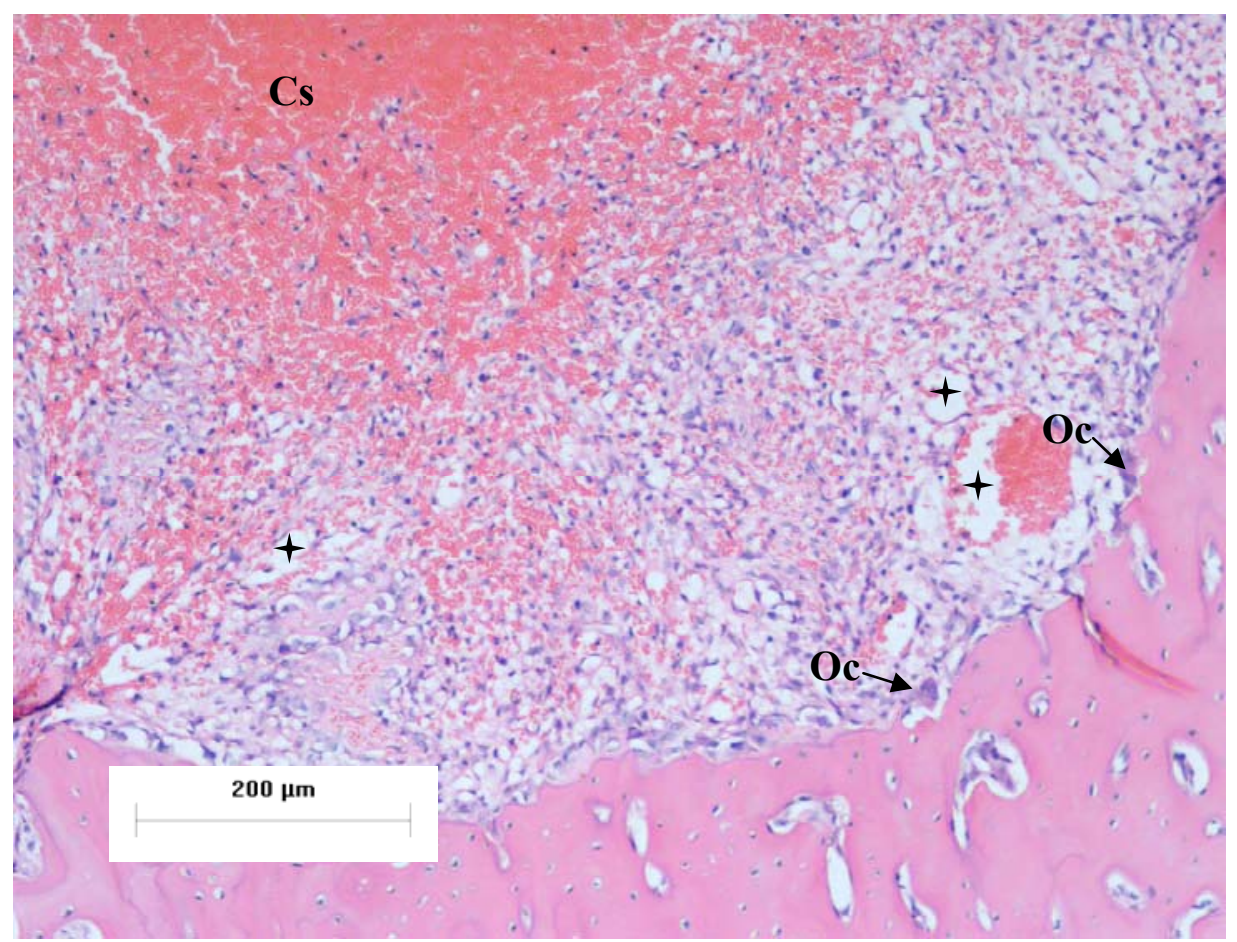

Figura 16 - Controle 5 dias de pós-operatório. Observa-se remanescente do coágulo sangüíneo (Cs), vasos sangüíneos e osteoclastos próximos à cortical do alvéolo dental. Objetiva de 10x. 


\section{5 dias de pós-operatório}

Observaram-se nos alvéolos dentais nesse período de tempo as seguintes características em comum: proliferação de fibroblastos com disposição mais organizada, presença de células inflamatórias em áreas isoladas, alguns pontos de reabsorção óssea nas paredes medial e lateral, presença de osteoclastos, vários vasos sangüíneos, áreas de mineralização rodeadas por fibroblastos, áreas isoladas com remanescentes do coágulo sangüíneo e presença de trabéculas ósseas finas revestidas por diversos osteoblastos localizadas próximo às corticais. Quanto mais afastado das corticais, mais desorganizado era o osso em formação. Houve preenchimento ósseo parcial da porção central do alvéolo. Verificou-se ainda linha cementante entre a cortical alveolar e osso neoformado (Figuras 17, 18 e 19).

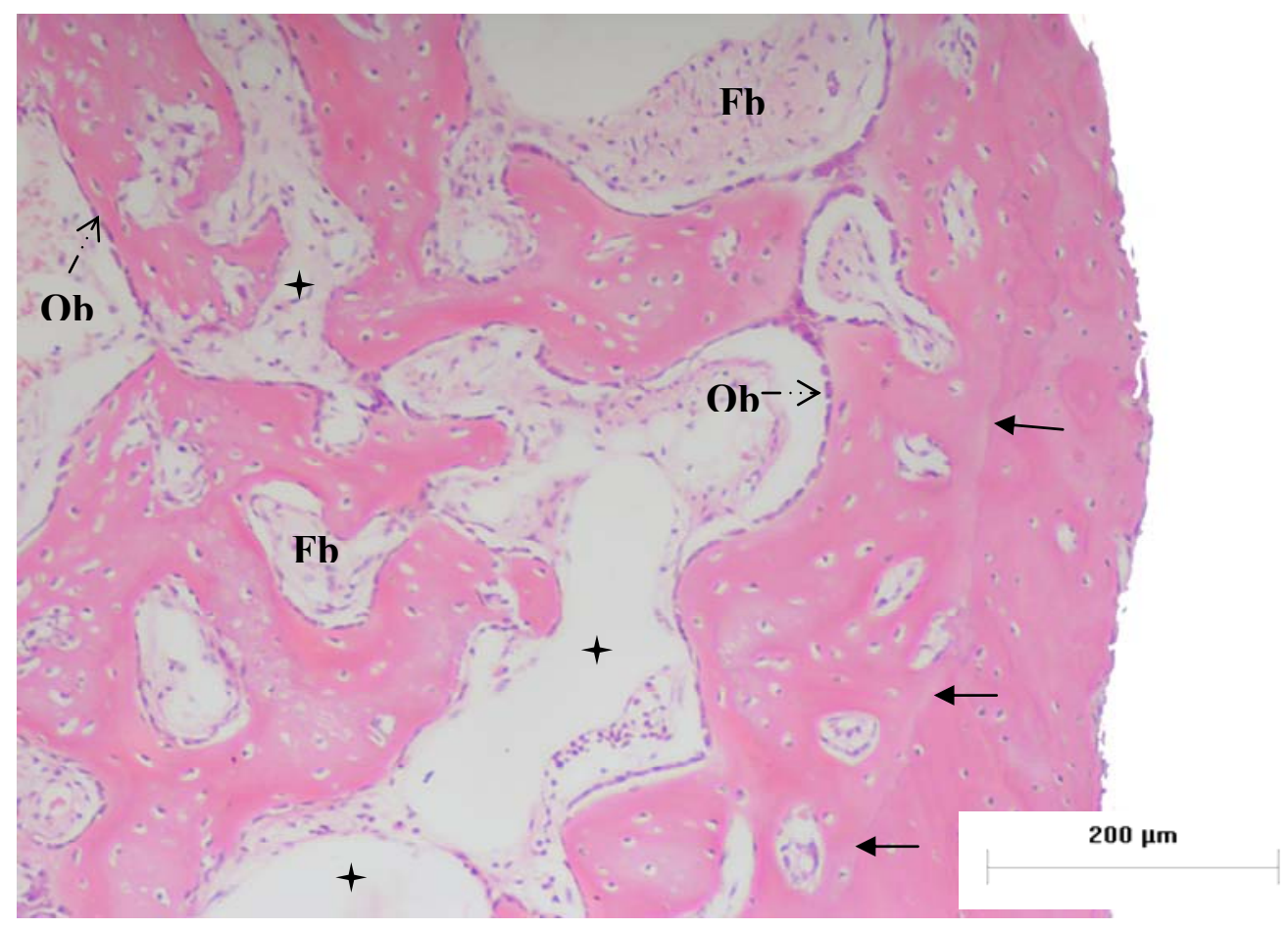

Figura 17 - Controle 15 dias de pós-operatório. Observam-se trabéculas ósseas neoformadas revestidas por osteoblastos $(\mathrm{Ob})$, fibroblastos $(\mathrm{Fb})$, vasos sangüíneos $(+)$ e linha cementante entre cortical alveolar e osso neoformado (setas completas). Objetiva de 10x. 


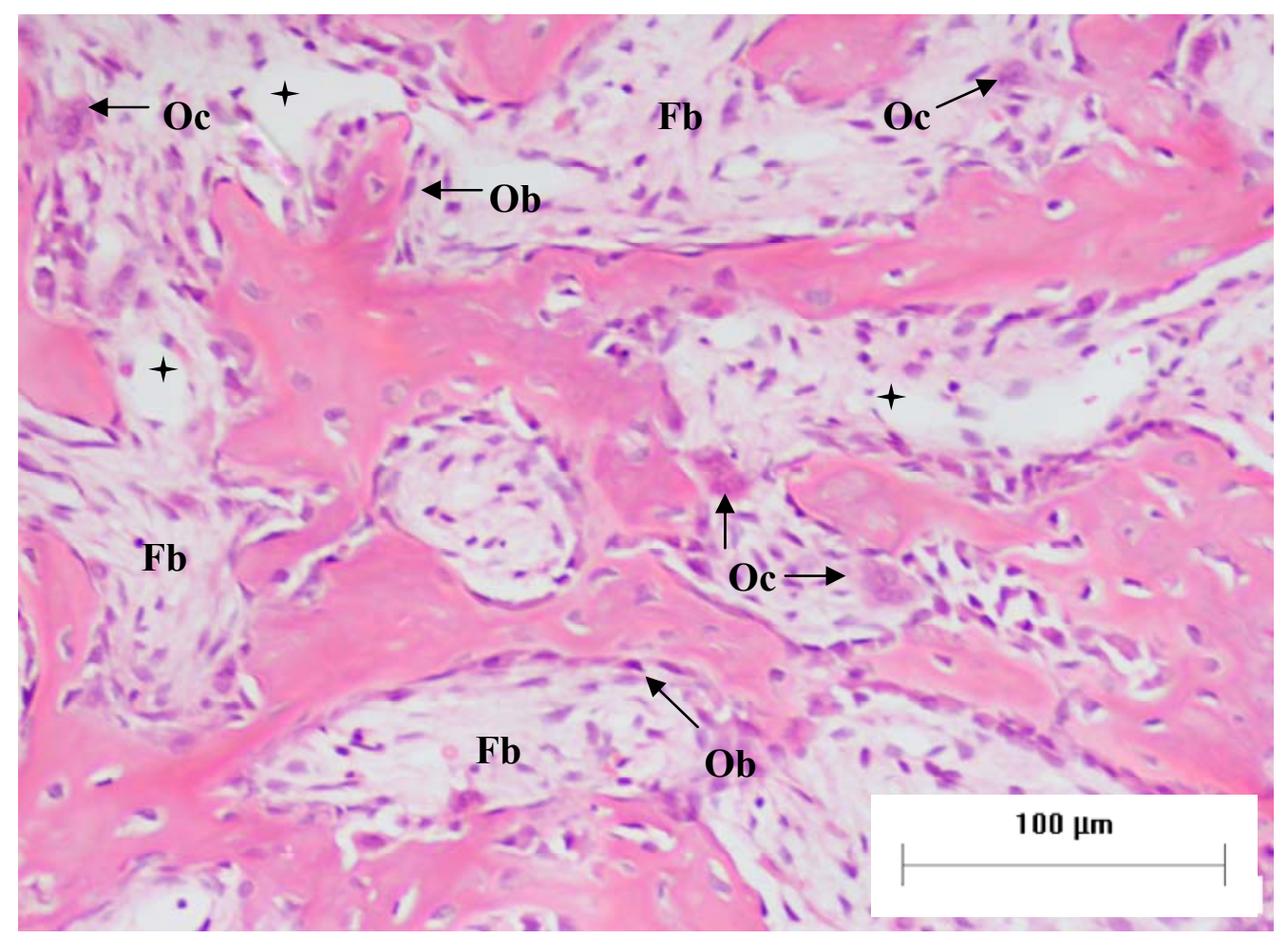

Figura 18 - Controle 15 dias de pós-operatório. Notam-se trabéculas ósseas imaturas revestidas por osteoblastos $(\mathrm{Ob})$, fibroblastos $(\mathrm{Fb})$, osteoclastos $(\mathrm{Oc})$ e vasos sangüíneos $\left({ }^{+}\right)$. Objetiva de 20x.

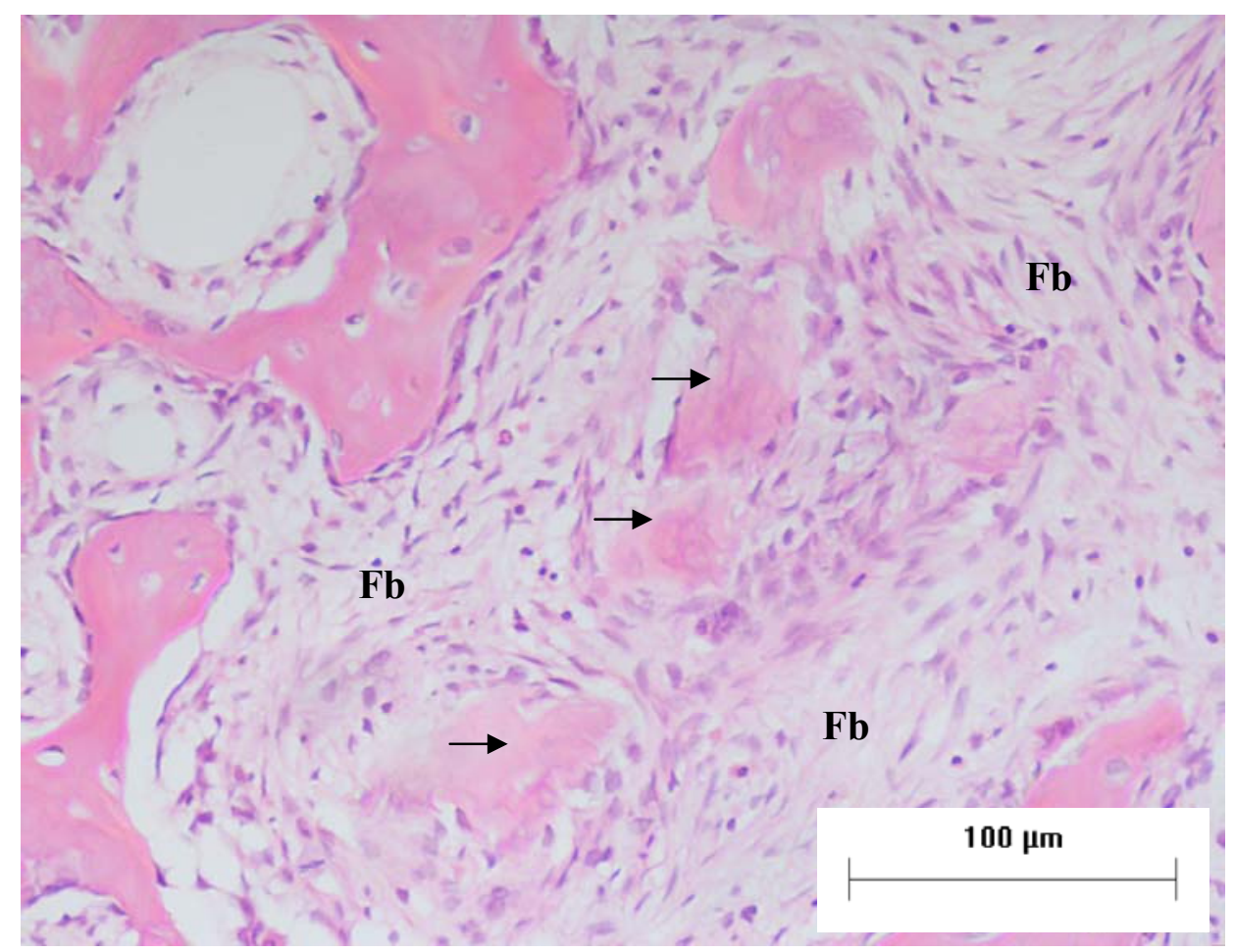

Figura 19 - Controle 15 dias de pós-operatório. Identificam-se áreas de neoformação óssea (setas) rodeadas por fibroblastos (Fb). Objetiva de 20x. 


\section{1 dias de pós-operatório}

Identificou-se nos alvéolos dentais uma aparente diminuição de fibroblastos ocupando os espaços intertrabeculares e menos células inflamatórias. Vasos sangüíneos, alguns pontos de reabsorção das paredes medial e lateral, presença moderada de osteoclastos, osso imaturo circundado por fibroblastos, trabéculas ósseas mais espessadas e organizadas com amplos espaços entre si ocupando a periferia e parte da porção central do alvéolo também foram observados. Linha cementante entre a cortical alveolar e osso neoformado também foi observada (Figuras 20 a 23).

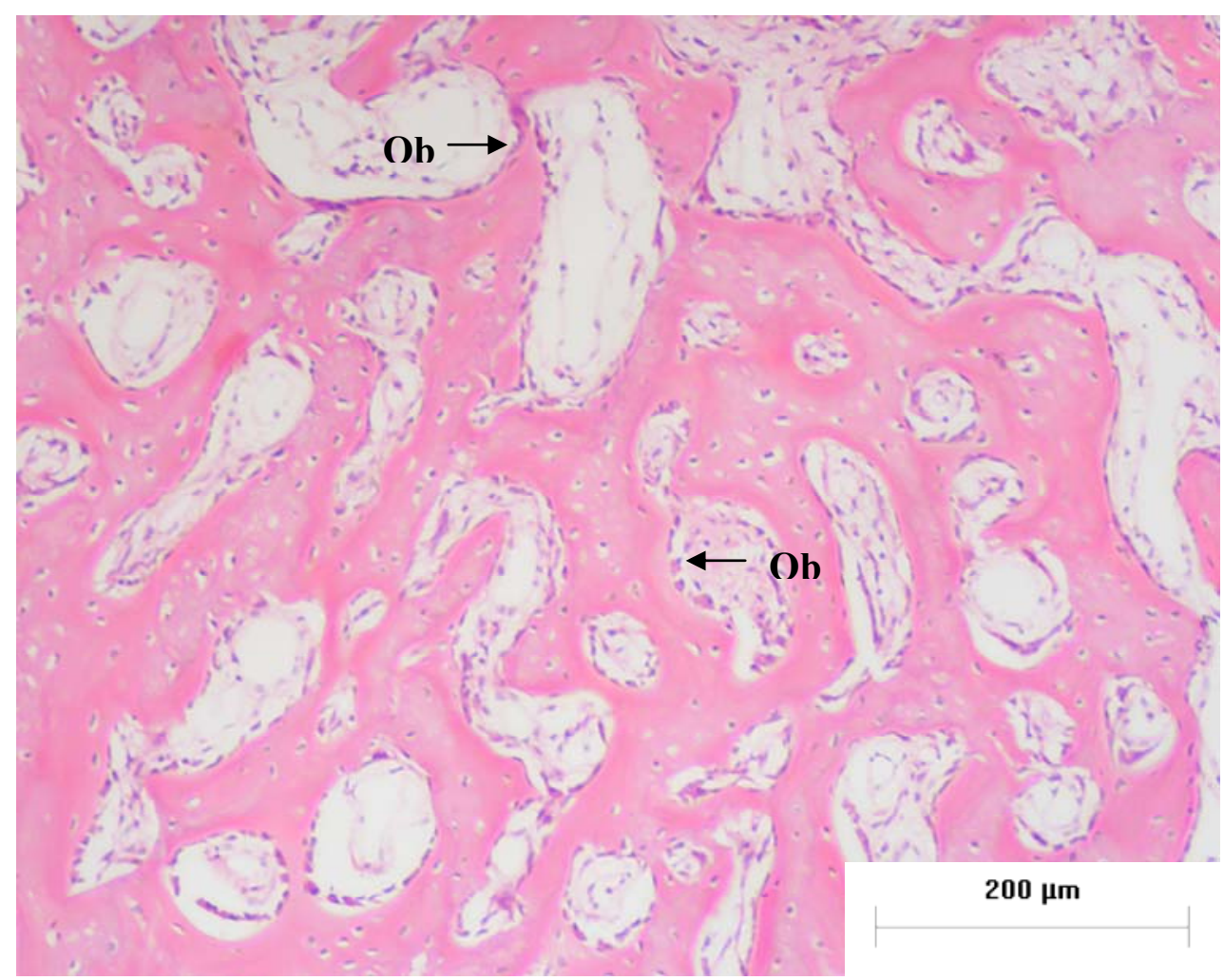

Figura 20 - Controle 21 dias de pós-operatório. Observam-se trabéculas ósseas bem definidas circundadas por osteoblastos $(\mathrm{Ob})$. Objetiva de 10x. 


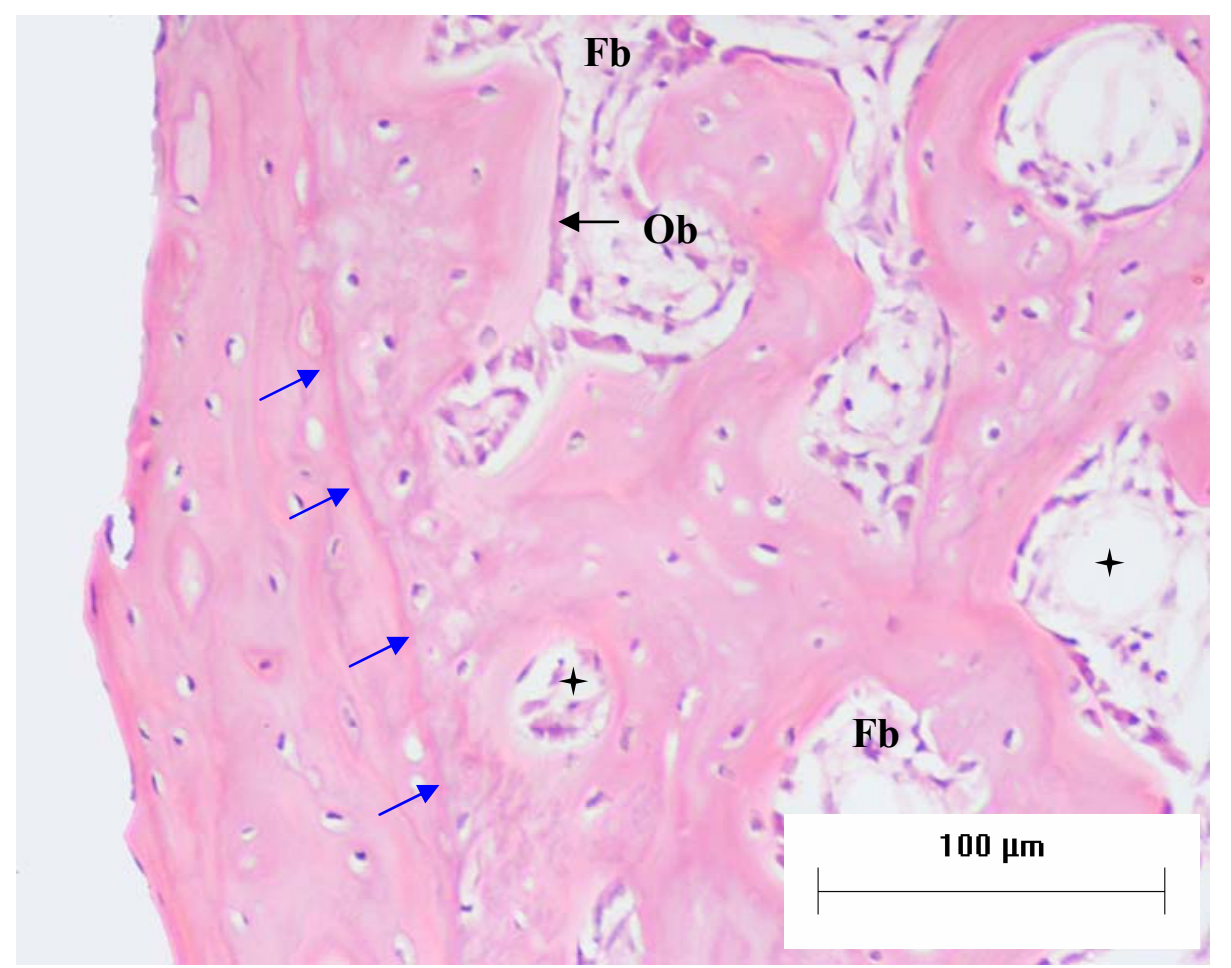

Figura 21 - Controle 21 dias de pós-operatório. Notam-se trabéculas ósseas revestidas por osteoblastos $(\mathrm{Ob})$, vasos sangüíneos $(+)$, fibroblastos $(\mathrm{Fb})$ e linha cementante entre a cortical alveolar e tecido ósseo neoformado (setas azuis). Objetiva de 20x.

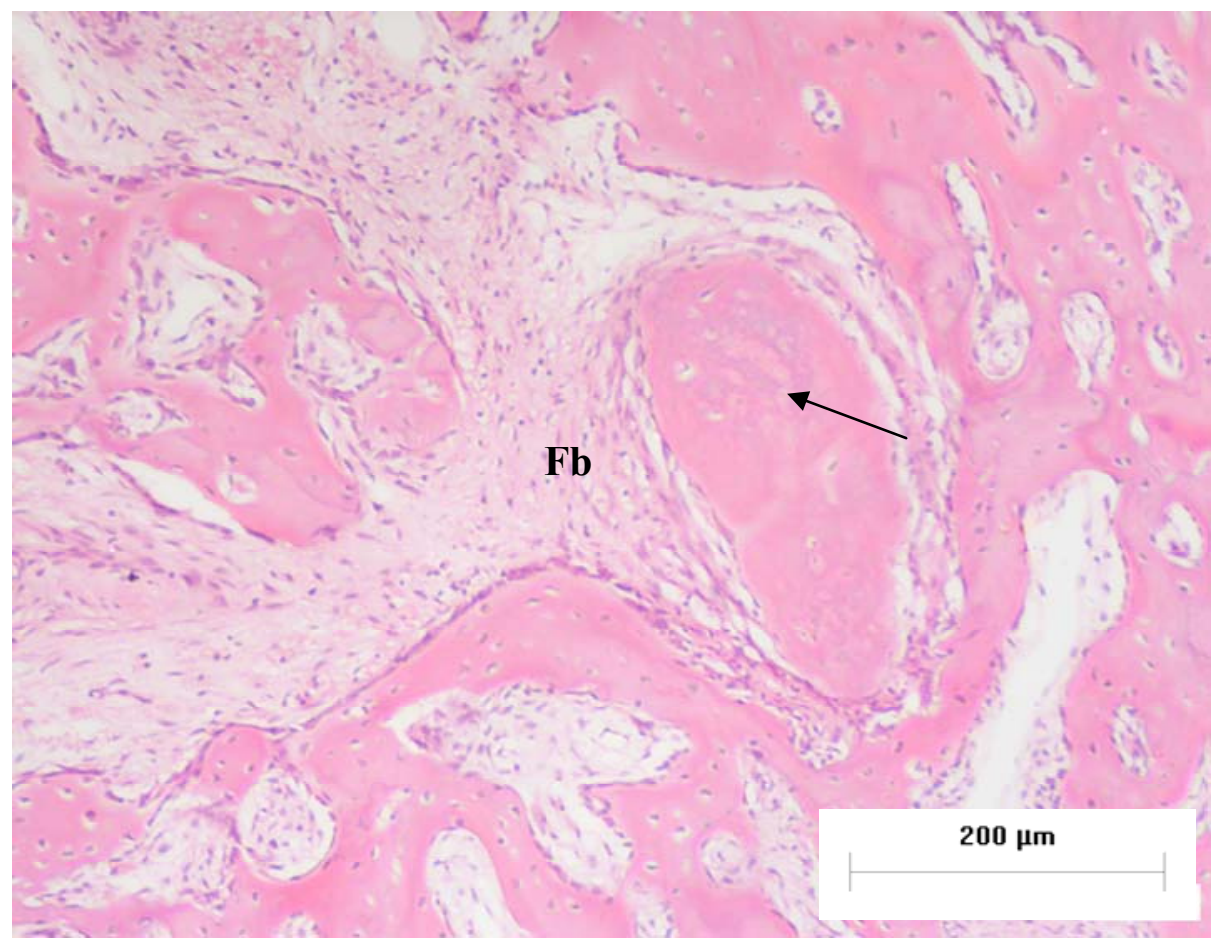

Figura 22 - Controle 21 dias de pós-operatório. Observa-se osso neoformado desorganizado (seta) circundado por fibroblastos (Fb). Objetiva de 10x. 


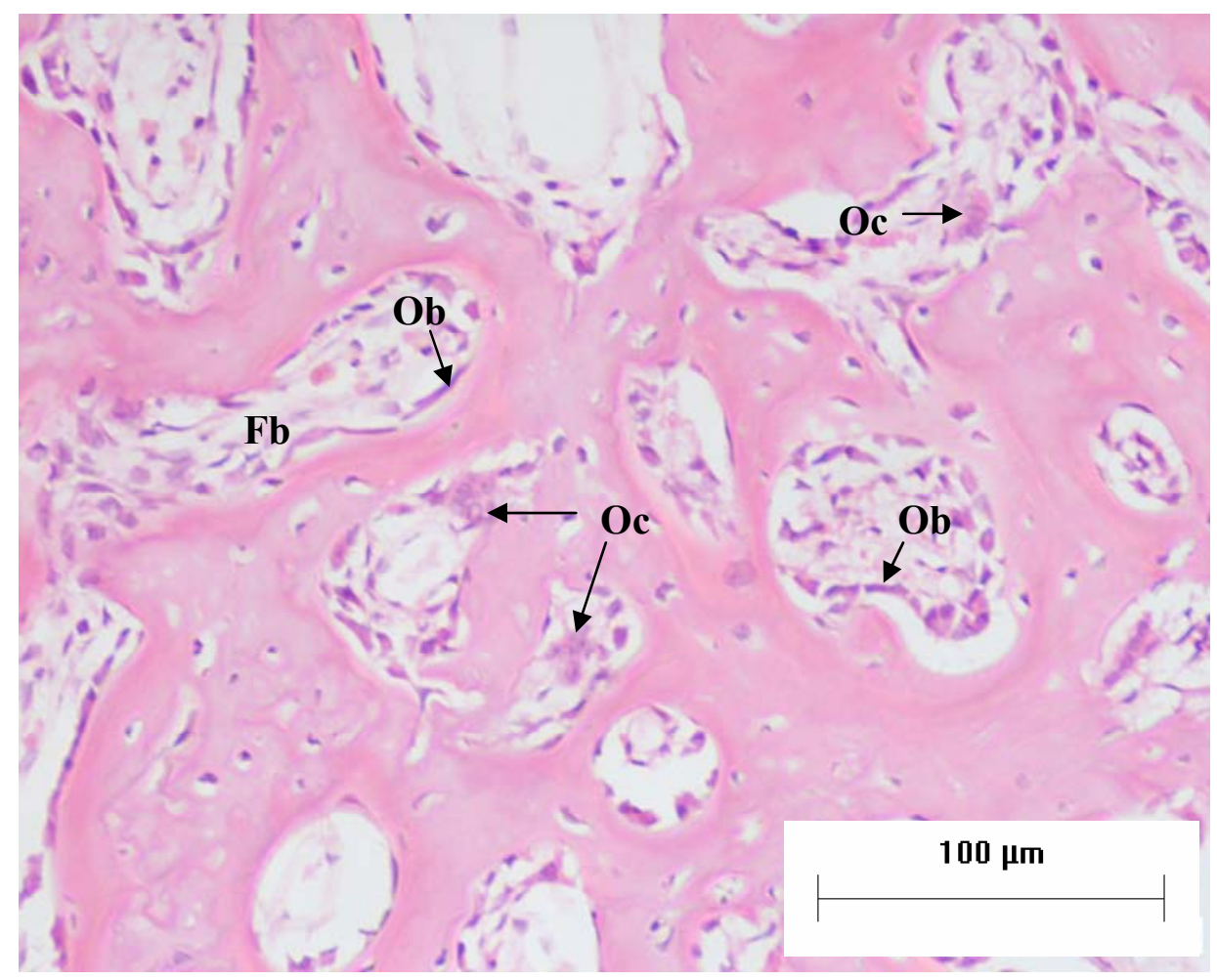

Figura 23 - Controle 21 dias de pós-operatório. Observam-se trabéculas ósseas revestidas por osteoblastos $(\mathrm{Ob})$. Osteoclastos $(\mathrm{Oc})$ e fibroblastos $(\mathrm{Fb})$ também são identificados. Objetiva de 20x.

\section{8 dias de pós-operatório}

Aos 28 dias de pós-operatório, os alvéolos dos ratos apresentaram aparente redução das áreas com fibroblastos, células inflamatórias em pontos isolados, alguns osteoclastos, maior espessamento das trabéculas ósseas com diminuição dos espaços intertrabeculares e identificação mais discreta da linha cementante entre a cortical alveolar e osso neoformado. Alguns animais ainda apresentavam áreas de mineralização. Apesar de grande parte do alvéolo estar preenchida por osso, não se constatou ocupação óssea completa na área central do alvéolo (Figuras 24 a 28). 


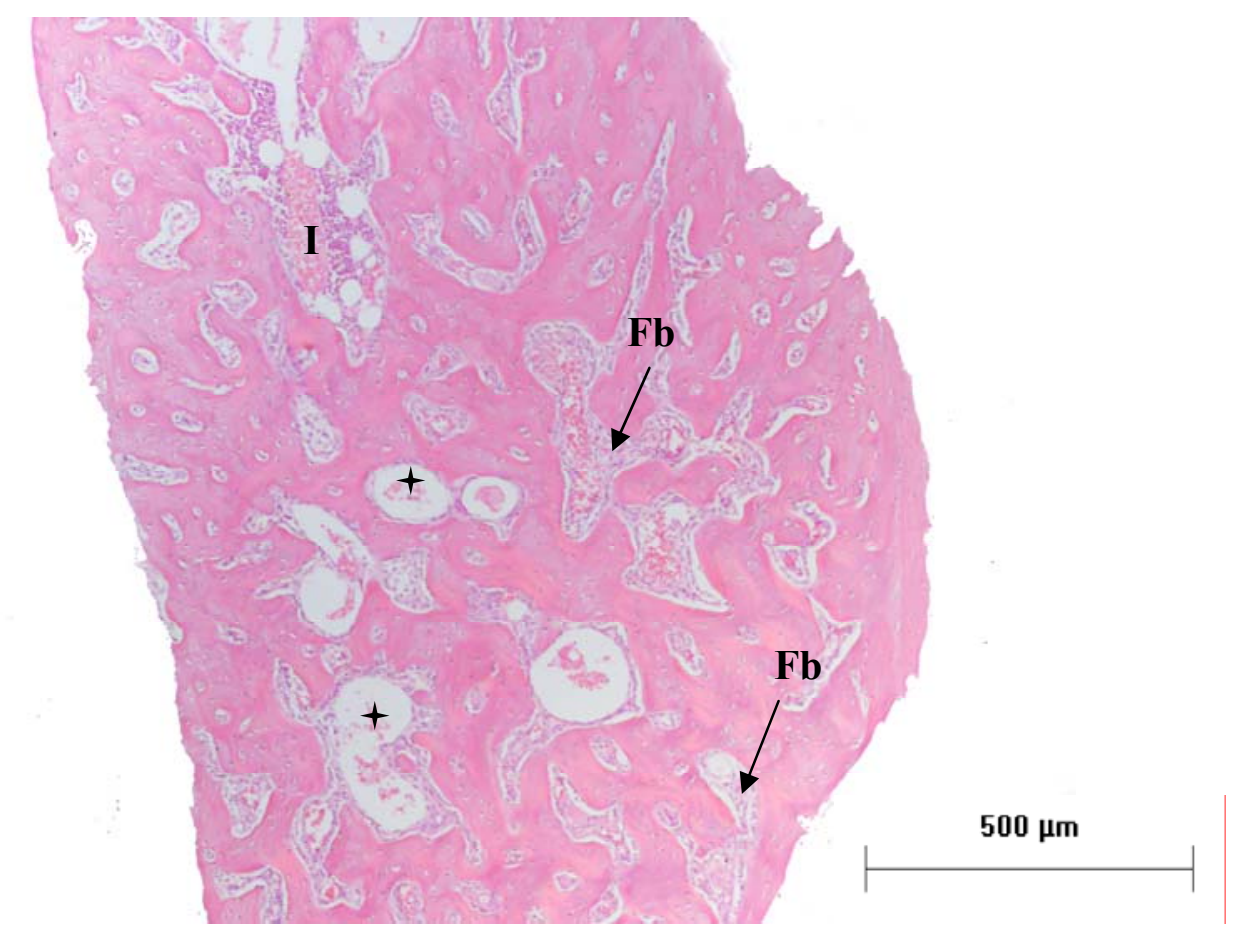

Figura 24 - Controle 28 dias de pós-operatório. Observa-se o trabeculado ósseo mais espessado ocupando todo alvéolo dental e áreas preenchidas por vasos sangüíneos $(t)$, células inflamatórias (I) e fibroblastos (Fb). Objetiva de 4x.

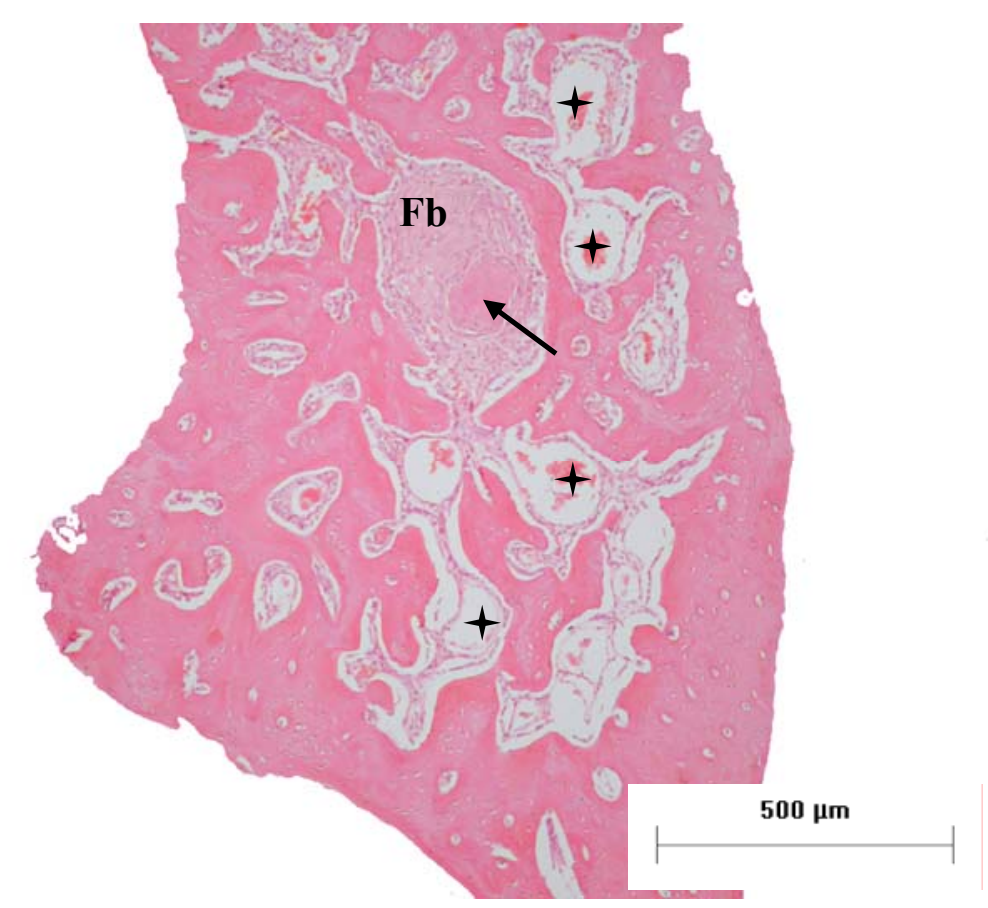

Figura 25 - Controle 28 dias de pós-operatório. Observam-se algumas áreas sem preenchimento ósseo, ocupadas por fibroblastos $(\mathrm{Fb})$ e vasos sangüíneos $(†)$. Nota-se ainda tecido ósseo imaturo ao centro do alvéolo dental circundado por fibroblastos (seta). Objetiva de $4 x$. 


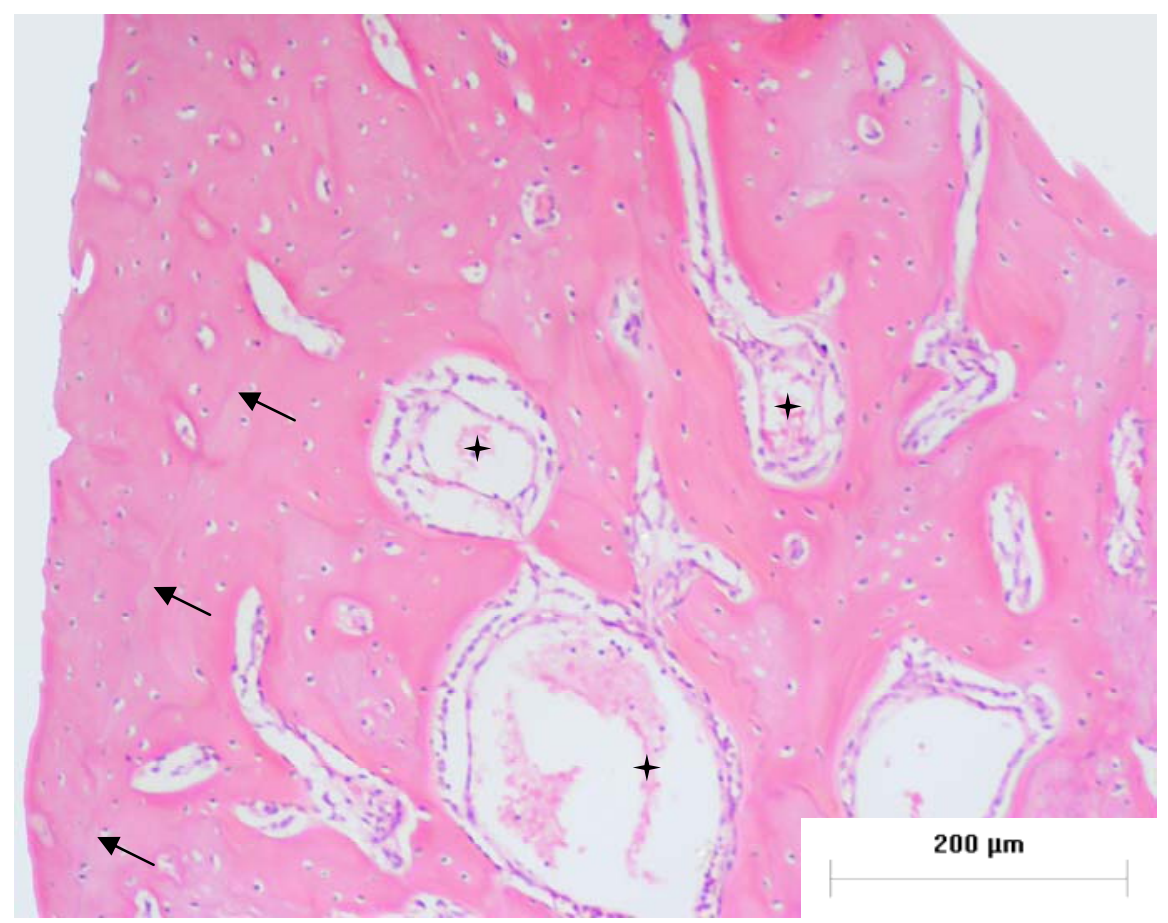

Figura 26 - Controle 28 dias de pós-operatório. Identificam-se vasos sangüíneos ( t) discreta linha cementante entre a cortical alveolar e osso neoformado (setas). Objetiva de 10x.

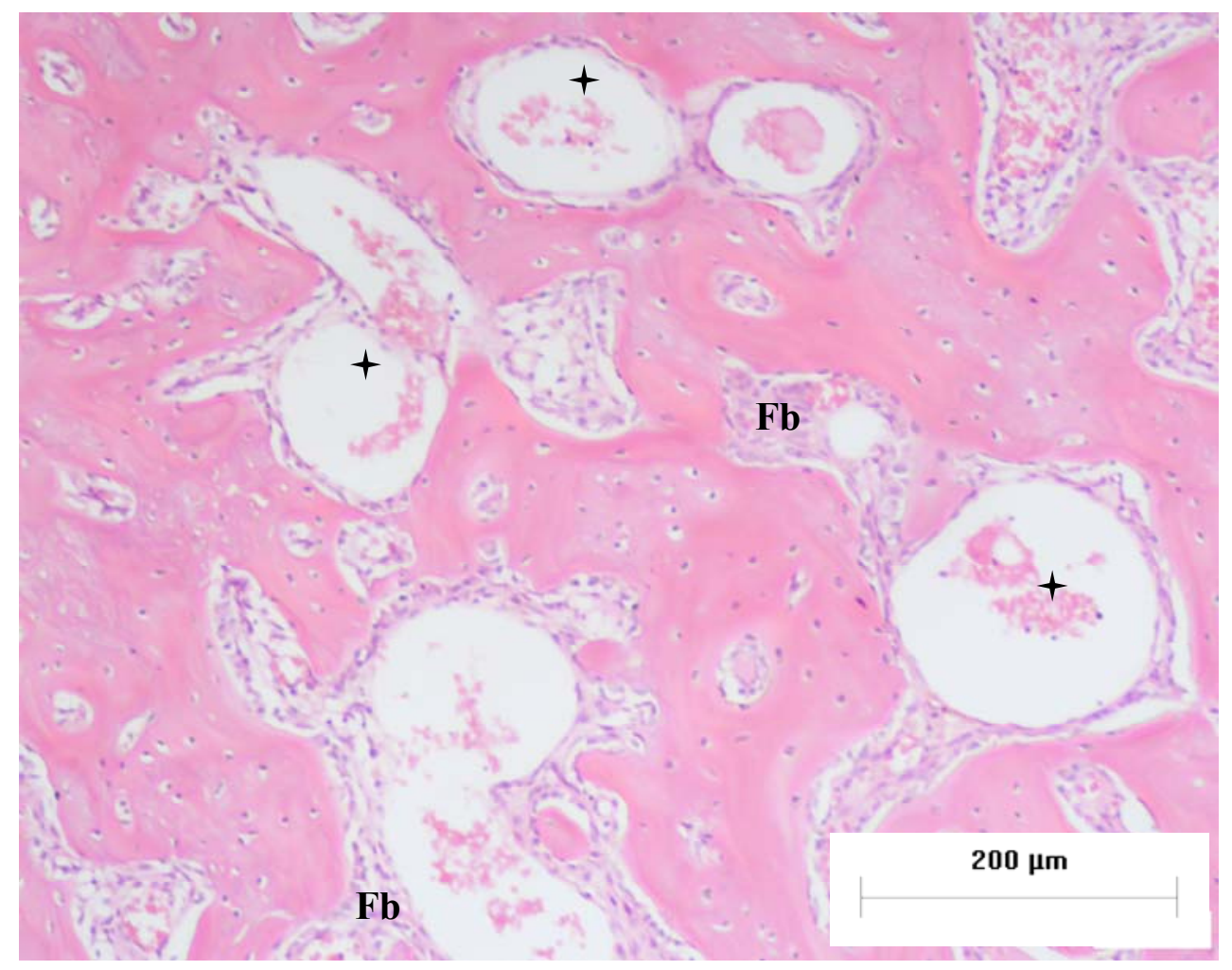

Figura 27 - Controle 28 dias de pós-operatório. Notam-se trabéculas ósseas espessadas, vasos sangüíneos $(+)$ e fibroblastos $(\mathrm{Fb})$. Objetiva de 10x. 


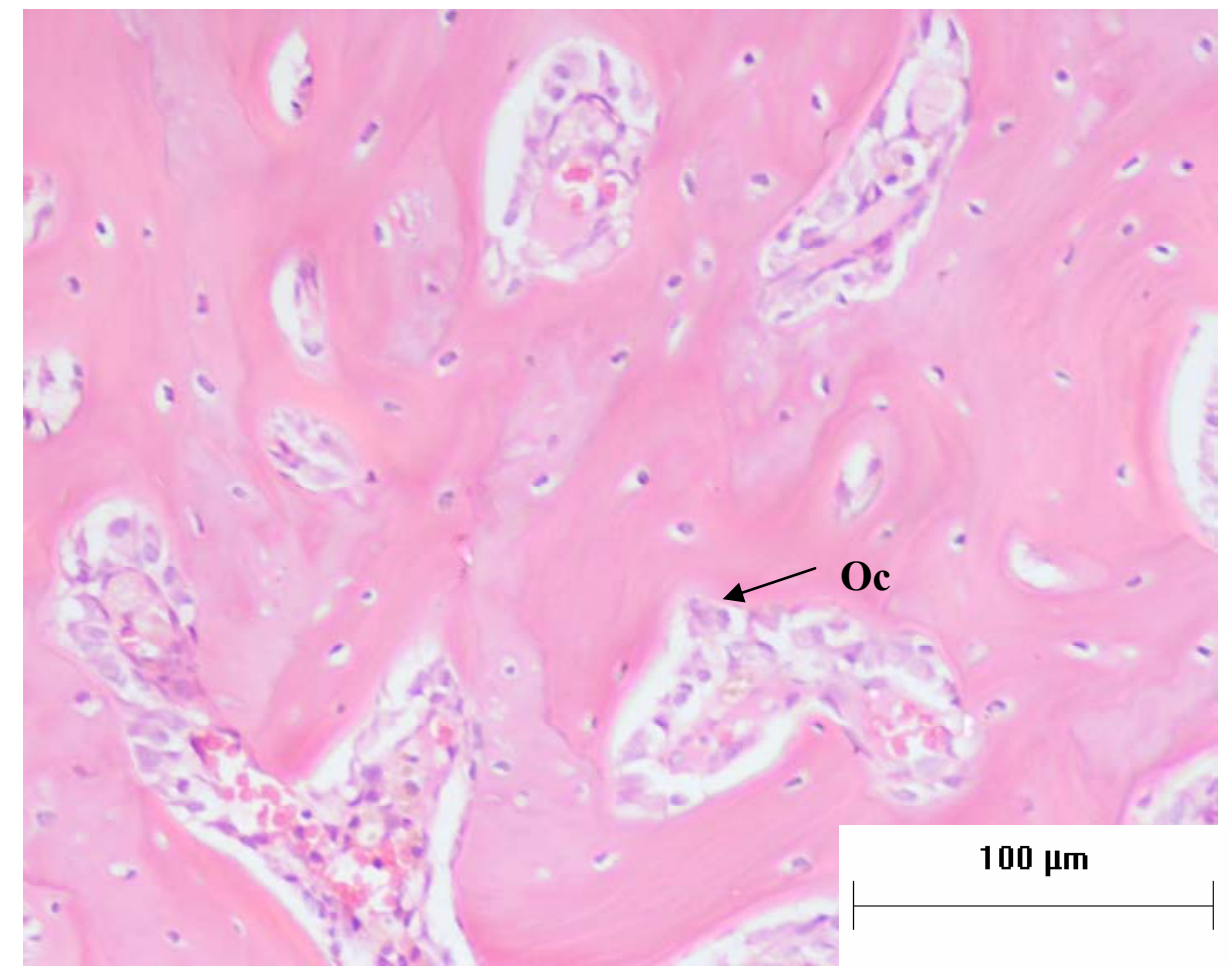

Figura 28 - Controle 28 dias de pós-operatório. Observa-se a presença de osteoclasto (Oc) formando depressão no trabeculado ósseo (lacuna de Howship). Objetiva de 20x.

\subsubsection{Grupo experimental}

\section{5 dias de pós-operatório}

Observou-se nos alvéolos dentais dos animais com 5 dias de pós-operatório os fragmentos de enxerto ósseo circundados por fibroblastos, células inflamatórias e pequenas áreas ocupadas por remanescentes do coágulo sangüíneo. Notam-se áreas de reabsorção óssea nos fragmentos de enxerto e corticais alveolares, com a presença de osteoclastos. Não foi observada neoformação óssea junto as corticais do alvéolo dental. Entretanto, constatou-se que ao redor dos fragmentos de enxerto há neoformação de osso com aparecimento de linhas cementantes entre o enxerto e o osso neoformado. Verificou-se ainda que os fragmentos de enxerto apresentaram lacunas onde se situavam osteócitos, que sofreram morte celular após enxertia no leito receptor. Vasos sangüíneos também foram identificados (Figuras 29 a 33). 


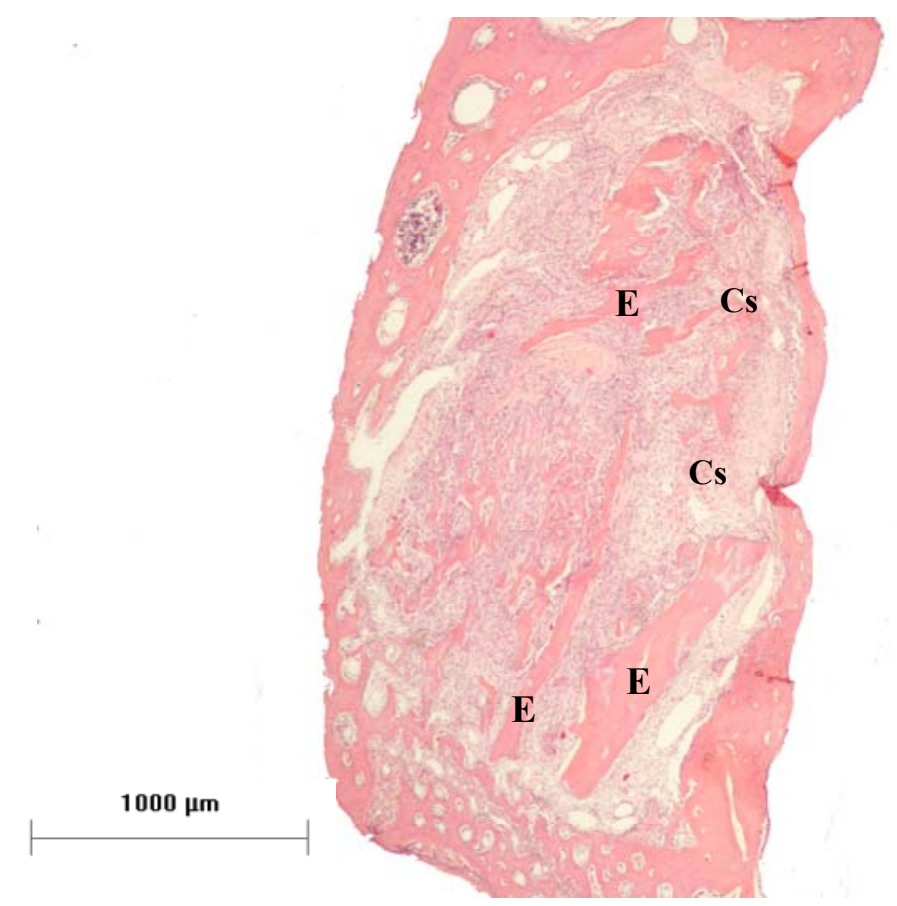

Figura 29 - Experimental 5 dias de pós-operatório. Observam-se os fragmentos de enxerto ósseo (E) no interior do alvéolo dental, circundados por fibroblastos e células inflamatórias. Pequenas áreas são ocupadas por remanescente do coágulo sangüíneo (Cs). Objetiva de 2x.

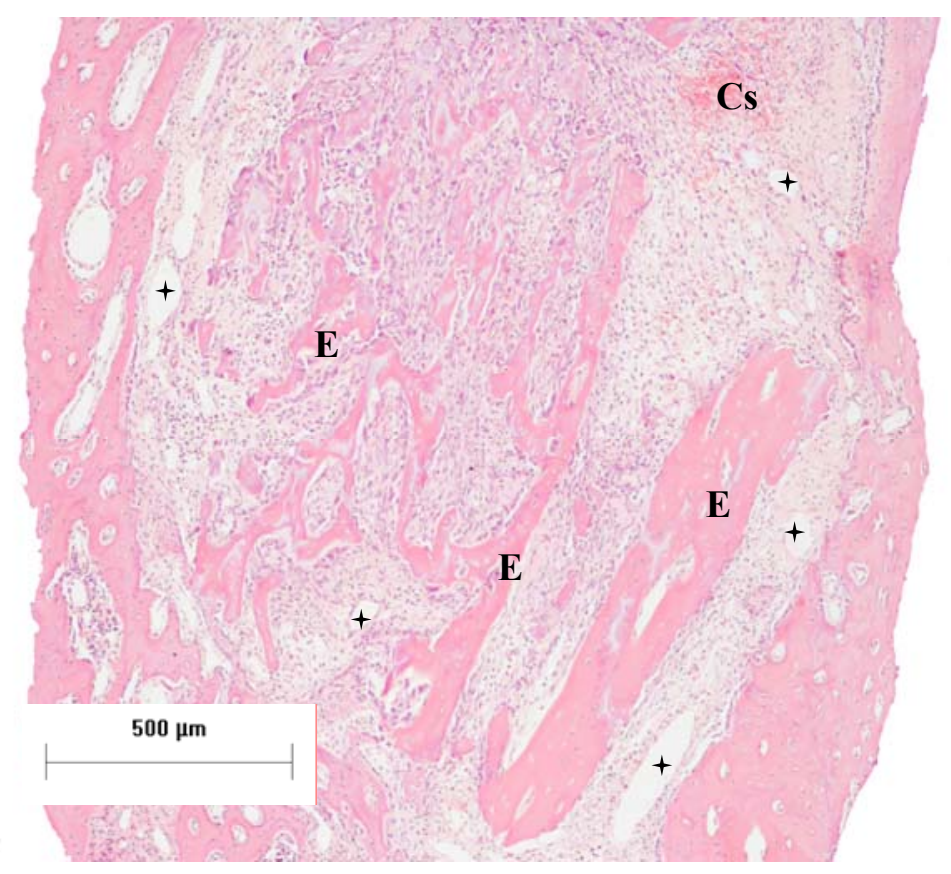

Figura 30 - Experimental 5 dias de pós-operatório. Observam-se os fragmentos de enxerto ósseo (E) no interior do alvéolo dental, circundados por fibroblastos e células inflamatórias. Identifica-se ainda uma pequena área ocupada por remanescente do coágulo sangüíneo (Cs) e a presença de vasos sangüíneos (+). Objetiva de 4x. 


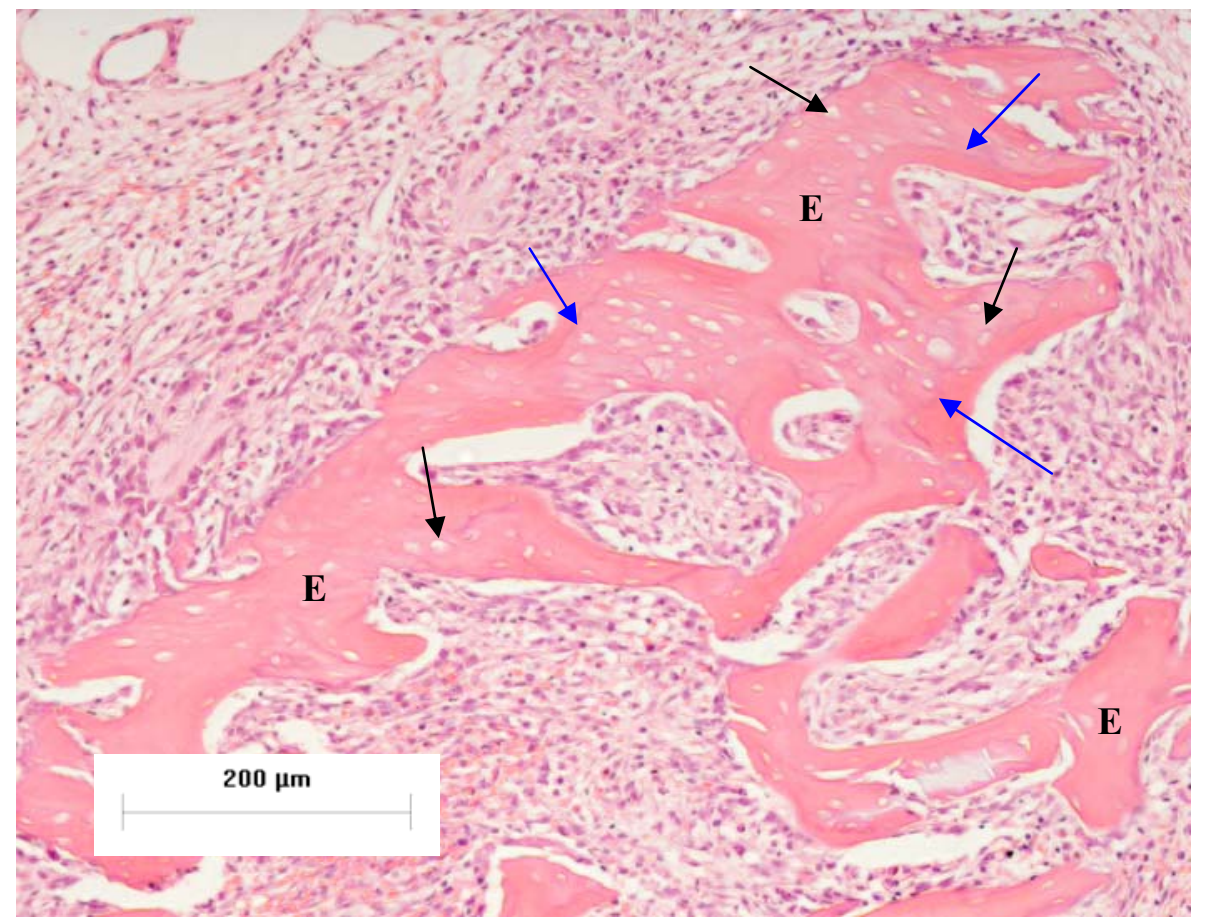

Figura 31 - Experimental 5 dias de pós-operatório. Observa-se a deposição de osso sobre os fragmentos de enxerto ósseo (E) formando linhas cementantes (seta azul). Os fragmentos de enxerto apresentam lacunas onde se encontravam os osteócitos (seta preta) e estão circundados por fibroblastos e células inflamatórias. Objetiva de 10x.

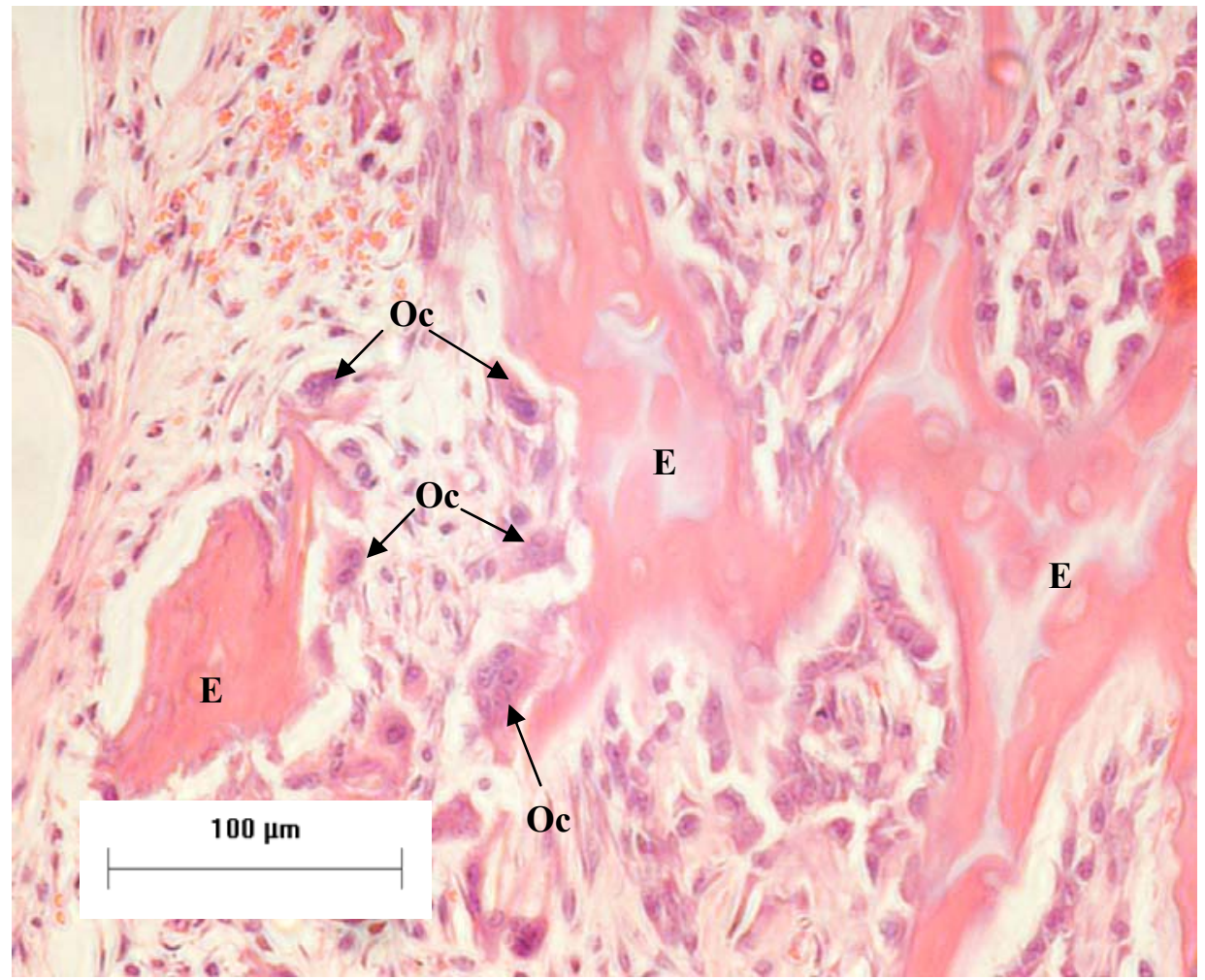

Figura 32 - Experimental 5 dias de pós-operatório. Identificam-se osteoclastos (Oc) próximos aos fragmentos de enxerto ósseo (E). Objetiva de 20x. 


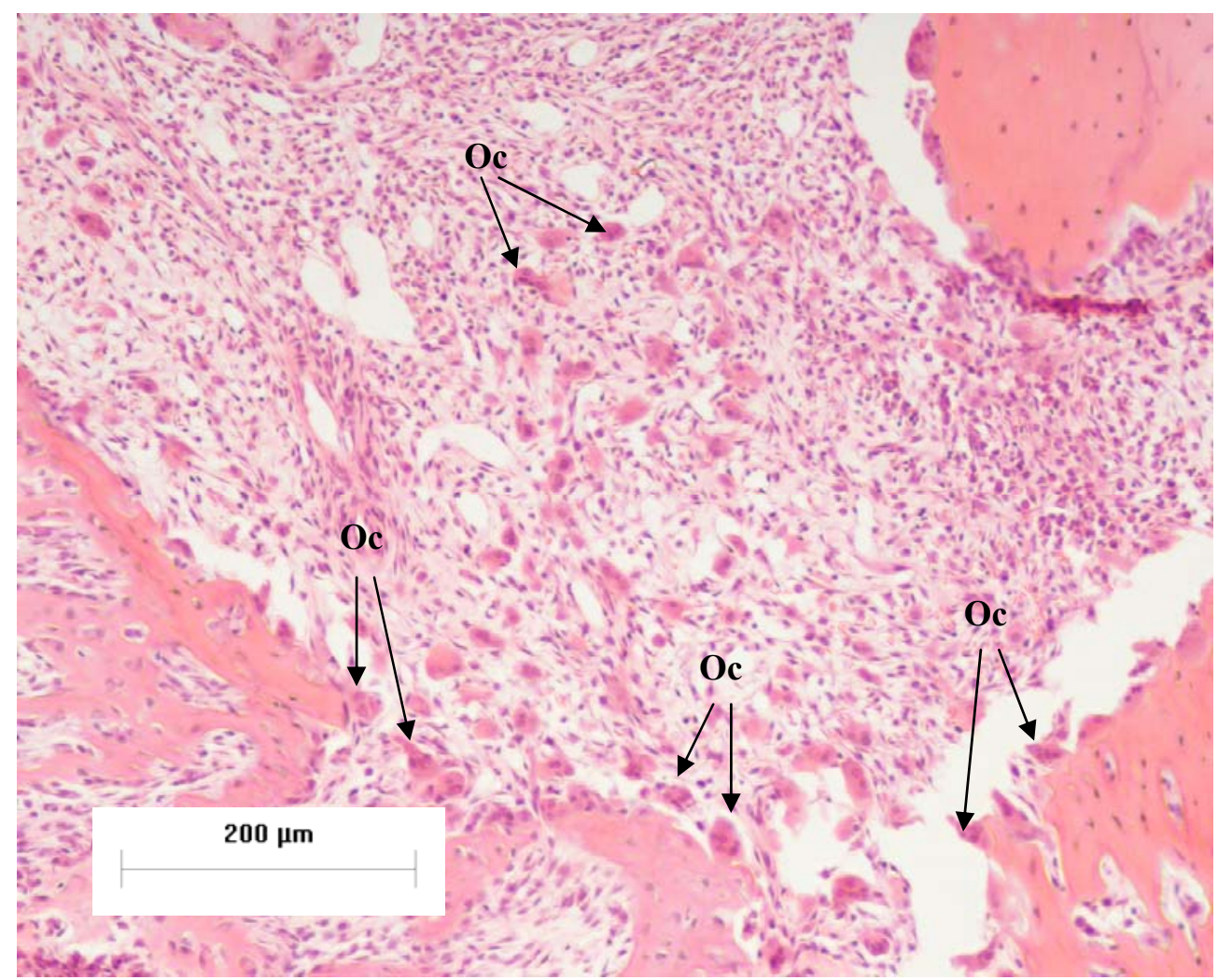

Figura 33 - Experimental 5 dias de pós-operatório. Observam-se diversos osteoclastos $(\mathrm{Oc})$ próximos à cortical do alvéolo dental. Objetiva de 10x.

\section{5 dias de pós-operatório}

Os alvéolos dentais dos animais com 15 dias de pós-operatório apresentaram grande quantidade de vasos sangüíneos, trabéculas ósseas revestidas por osteoblastos e distribuídas nas áreas periféricas do alvéolo e ao redor dos fragmentos de enxerto. Observou-se ainda a presença de osteoclastos, áreas de ossificação caracterizando um osso imaturo e espaços intertrabeculares amplos ocupados por fibroblastos e células inflamatórias. Nota-se também a incorporação do enxerto ósseo com as trabéculas neoformadas, identificando-se uma linha cementante entre eles. Os fragmentos de enxerto ósseo apresentaram vasos sangüíneos que penetravam seu interior e lacunas vazias onde anteriormente se encontravam osteócitos. Constatou-se formação de osso em quase toda extensão do alvéolo dental. Todavia, as trabéculas ósseas apresentaram amplos espaços entre si, principalmente na porção central do alvéolo (Figuras 34 a 38). 


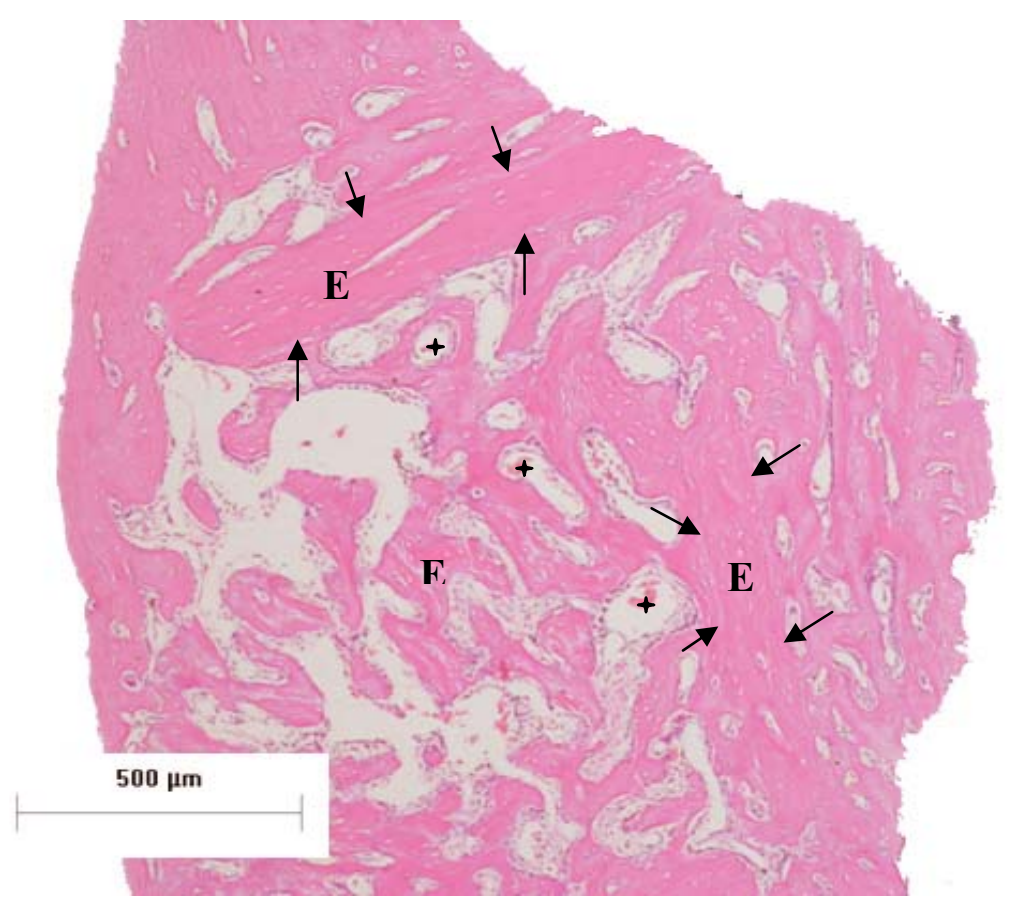

Figura 34 - Experimental 15 dias de pós-operatório. Observa-se a incorporação do enxerto ósseo (E) com o trabeculado neoformado, formando linhas cementantes (setas). Nota-se a presença de vasos sangüíneos $\left(^{+}\right.$) em toda extensão do alvéolo dental. Objetiva de 4x.

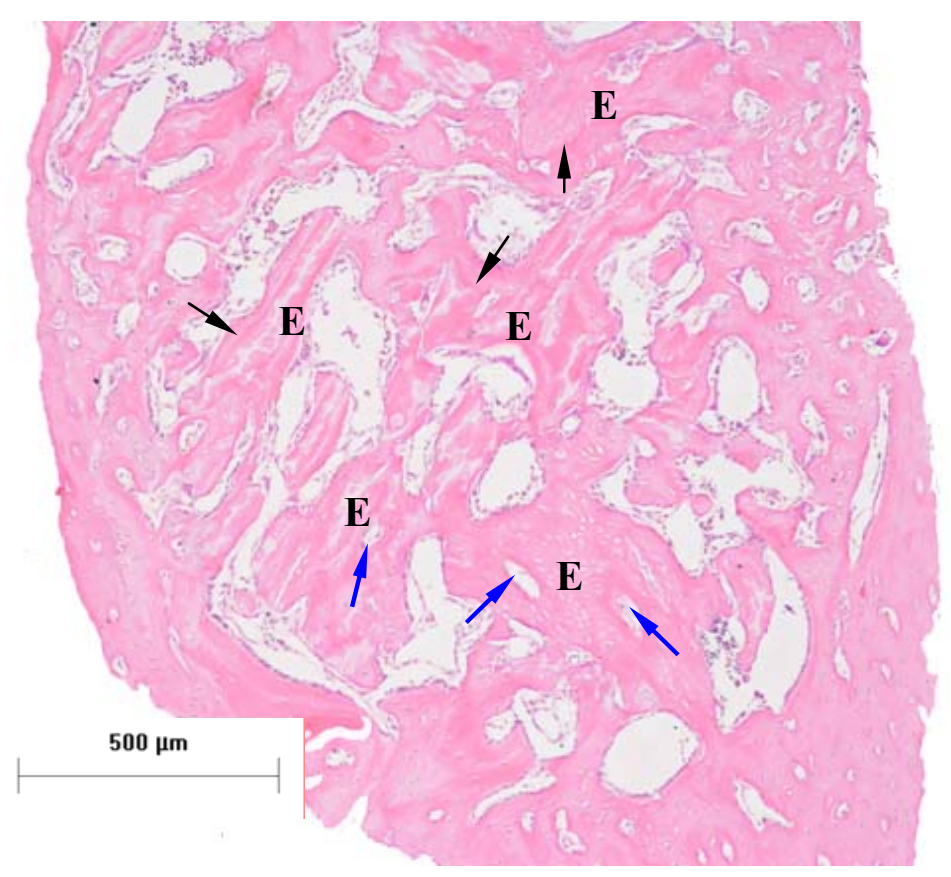

Figura 35 - Experimental 15 dias de pós-operatório. Observa-se a incorporação do enxerto ósseo (E) com o trabeculado neoformado, formando linhas cementantes (setas pretas). Nota-se a penetração de vasos sangüíneos nos fragmentos de enxerto (setas azuis). Objetiva de $4 \mathrm{x}$. 


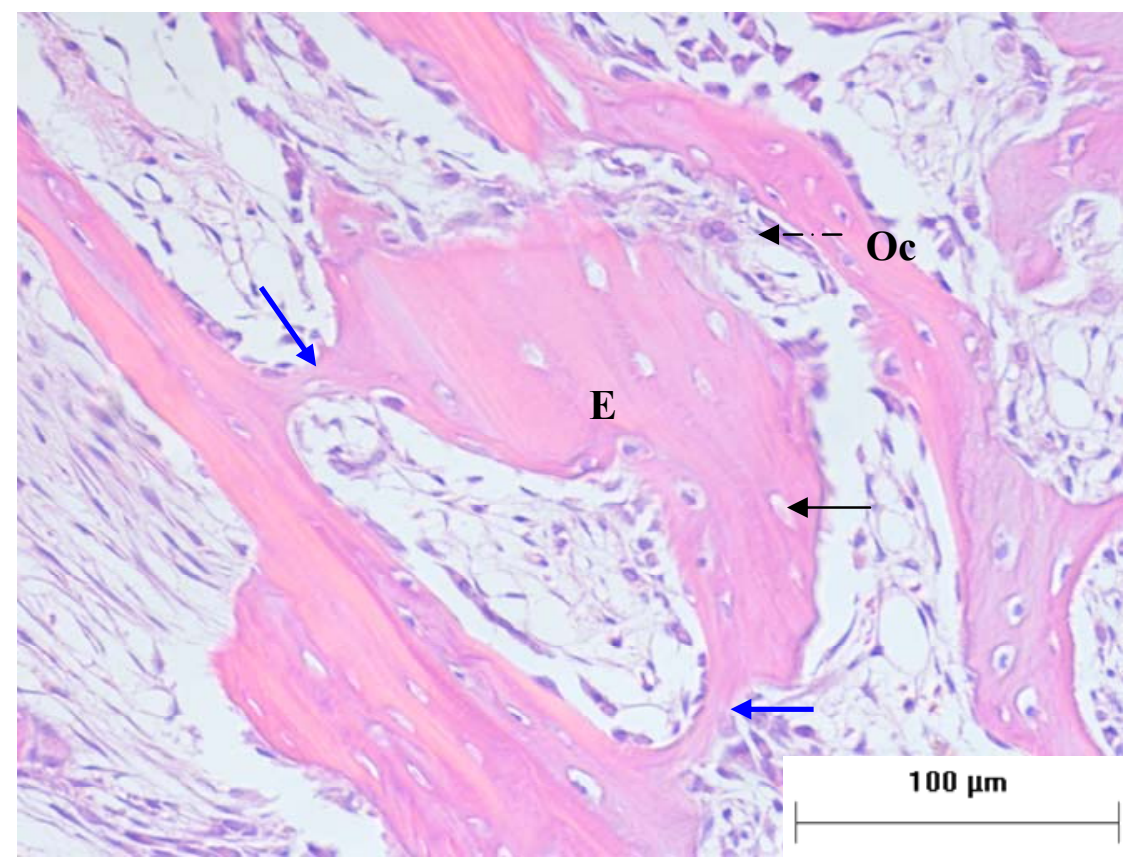

Figura 36 - Experimental 15 dias de pós-operatório. Observa-se a incorporação do enxerto ósseo (E) com o trabeculado neoformado (setas azuis). No fragmento de enxerto identificam-se as lacunas onde se encontravam os osteócitos (setas pretas). Na periferia do enxerto nota-se a presença de osteoclasto (Oc). Objetiva 20x.

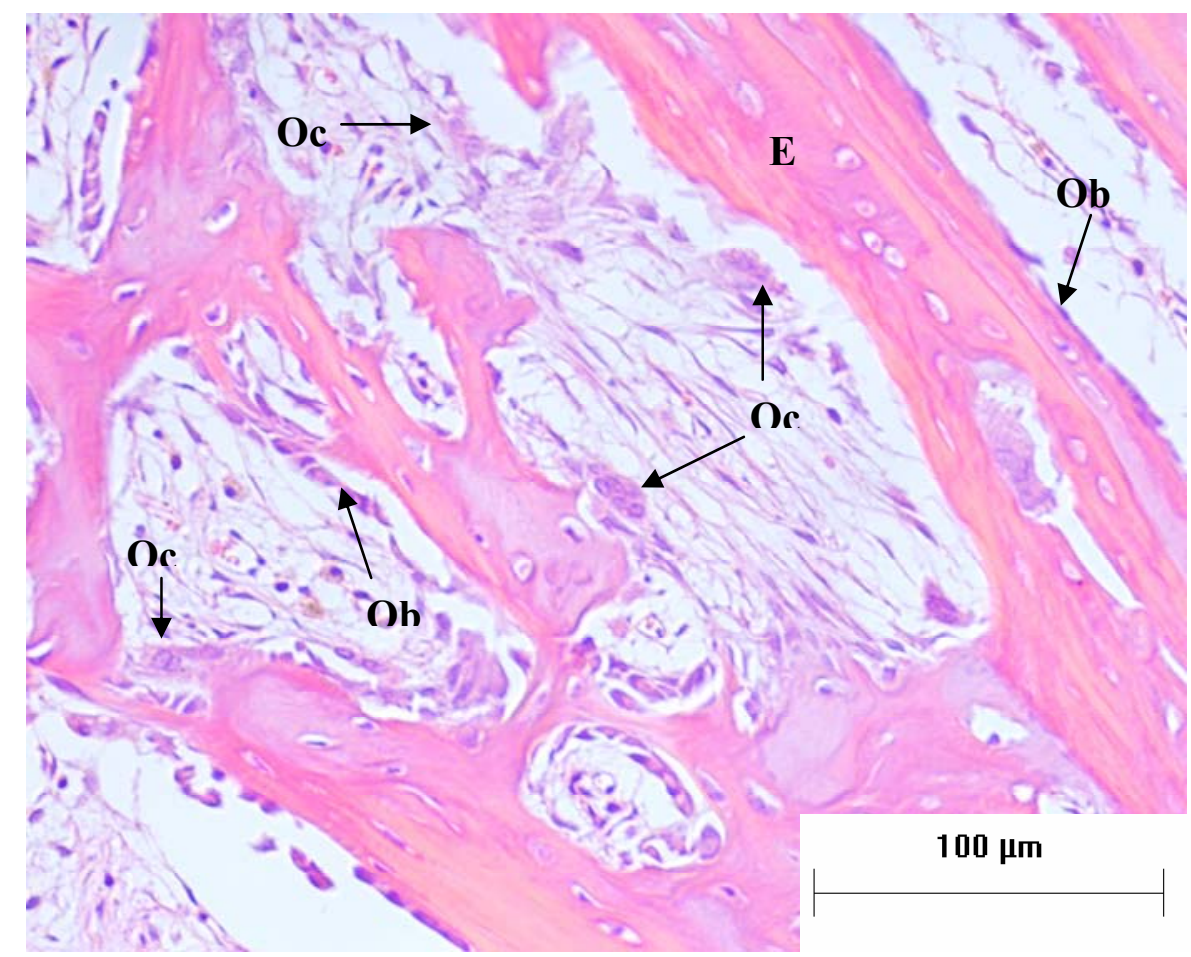

Figura 37 - Experimental 15 dias de pós-operatório. Observam-se osteoblastos (Ob) e osteoclastos (Oc) na superfície das trabéculas ósseas e do fragmento de enxerto ósseo. Objetiva de 20x. 


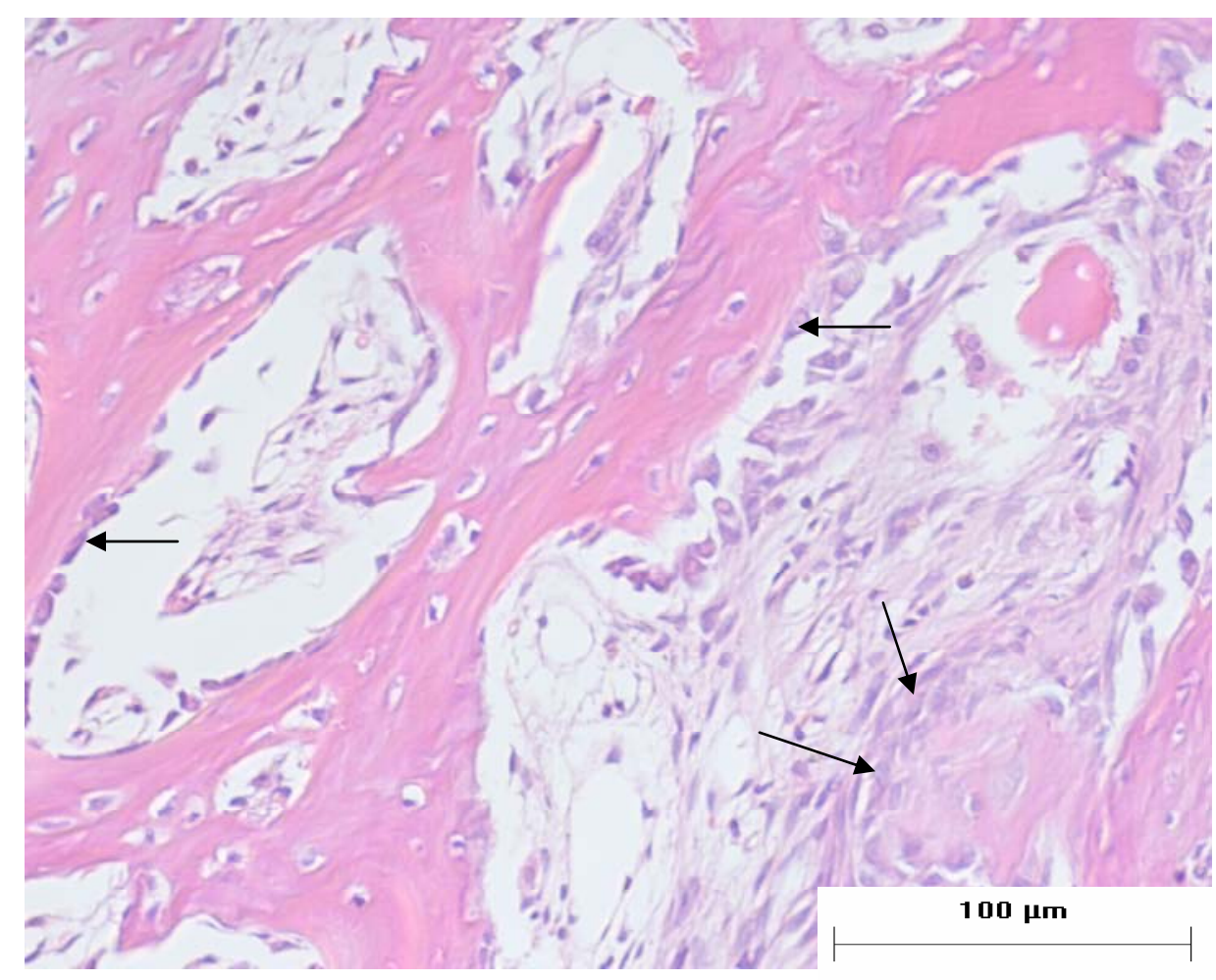

Figura 38 - Experimental 15 dias de pós-operatório. Notam-se osteoblastos circundando trabéculas ósseas bem definidas e em fase de mineralização (setas). Objetiva de 20x.

\section{1 dias de pós-operatório}

Os alvéolos dentais dos animais do grupo com 21 dias de pós-operatório apresentaram os enxertos ósseos incorporados ao trabeculado ósseo. A área ocupada por osso corresponde a quase toda extensão do alvéolo. Alguns alvéolos apresentaram espaços amplos sem preenchimento ósseo, principalmente na parte central (Figuras 39 e 40). Vasos sangüíneos são identificados em todo alvéolo com penetração vascular dos fragmentos de enxerto ósseo. Observou-se ainda a presença de células inflamatórias e fibroblastos nos espaços intertrabeculares e osteoclastos próximos ao tecido ósseo. Aparentemente houve uma diminuição na quantidade de osteoclastos nesse período de pós-operatório quando comparado aos períodos de 5 e 15 dias (Figuras 41 a 43). 


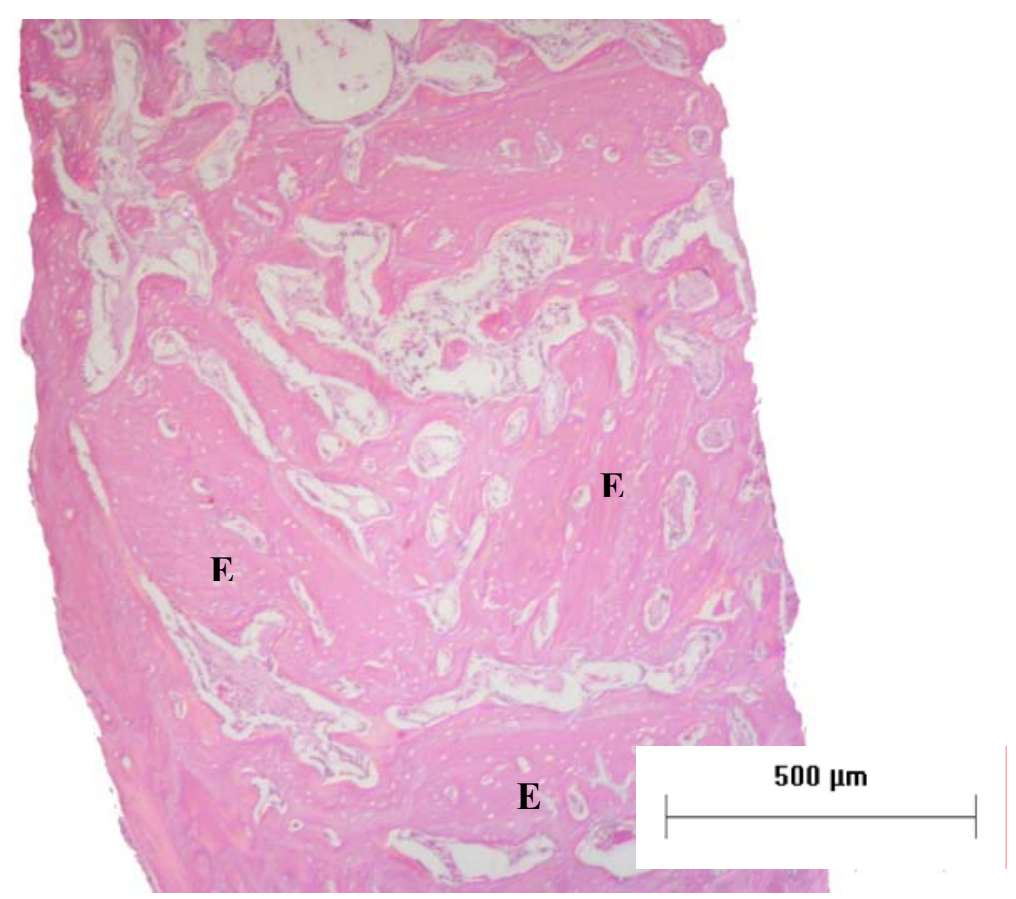

Figura 39 - Experimental 21 dias de pós-operatório. Observa-se o trabeculado ósseo integrado aos fragmentos de enxerto (E) ocupando a parte central do alvéolo.

Objetiva de $4 \mathrm{x}$.

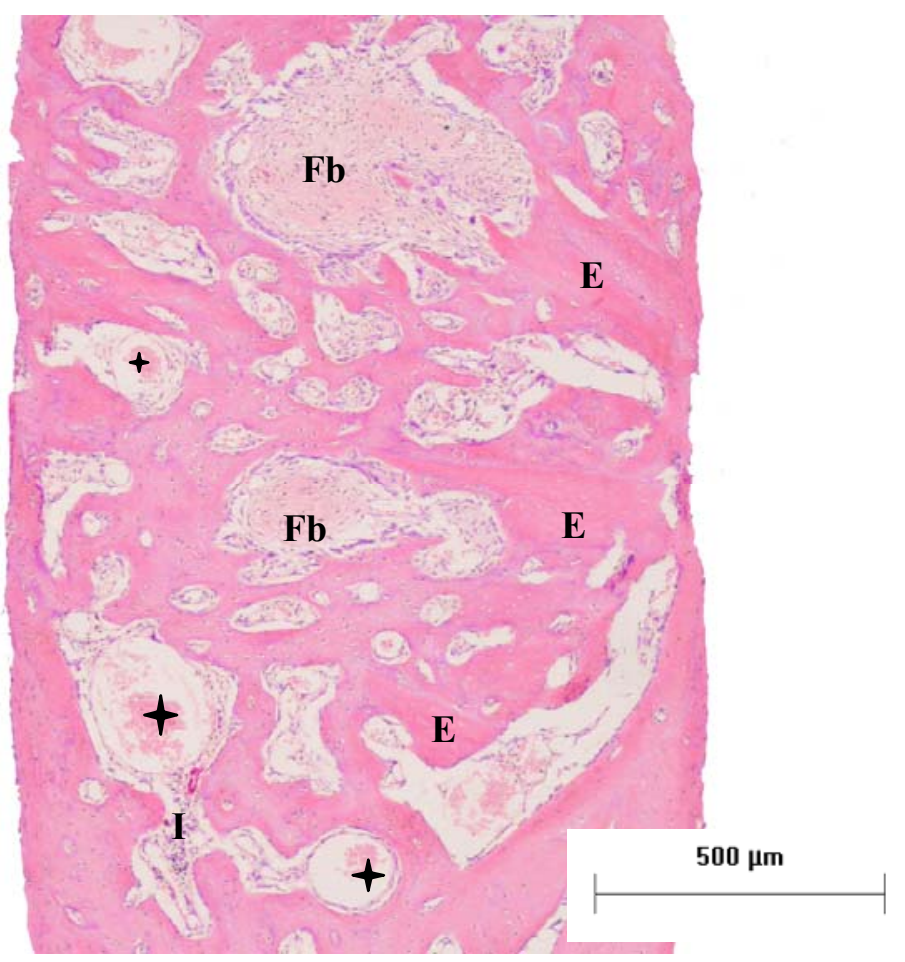

Figura 40 - Experimental 21 dias de pós-operatório. Observa-se o trabeculado ósseo integrado aos fragmentos de enxerto (E) ocupando grande parte do alvéolo. Os espaços intertrabeculares são preenchidos por fibroblastos $(\mathrm{Fb})$ e células inflamatórias (I). Vasos sangüíneos (†) também são identificados em toda extensão do alvéolo dental. Objetiva de 


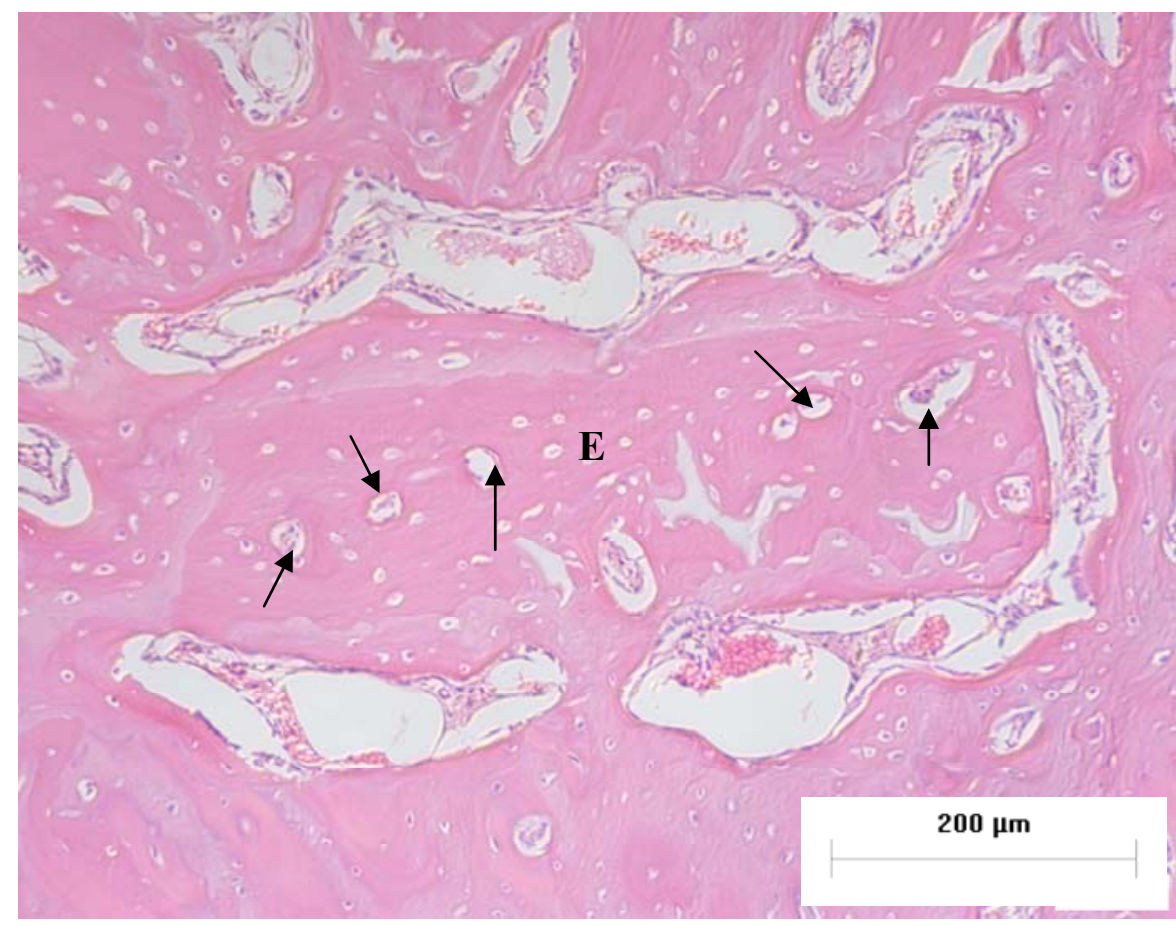

Figura 41 - Experimental 21 dias de pós-operatório. Observa-se enxerto ósseo (E) incorporado com as trabéculas neoformadas e penetrado por vasos sangüíneos (setas). Objetiva de 10x.

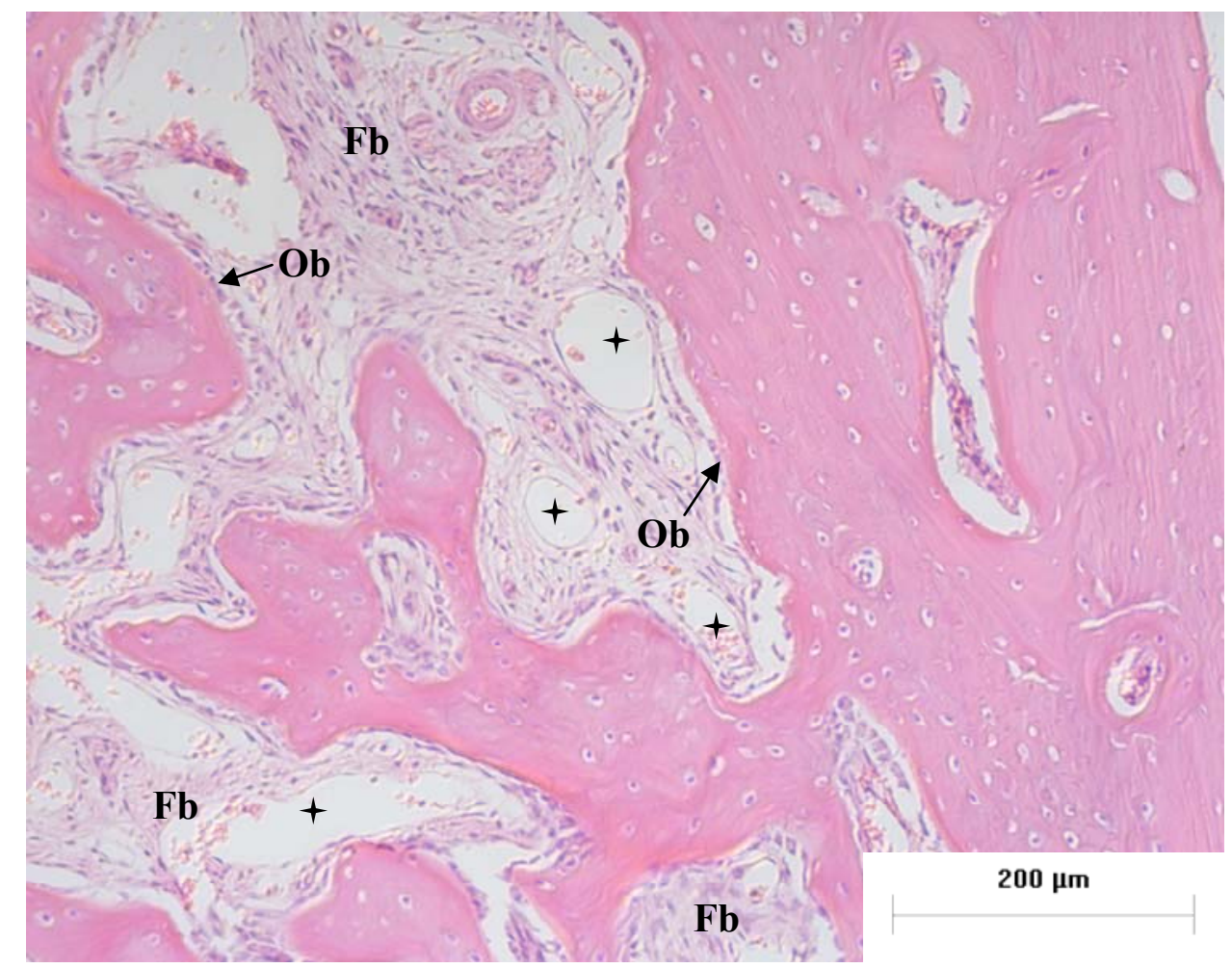

Figura 42 - Experimental 21 dias de pós-operatório. Notam-se trabéculas ósseas bem definidas circundadas por osteoblastos $(\mathrm{Ob})$, vasos sangüíneos $(+)$ e fibroblastos $(\mathrm{Fb})$. Objetiva de 10x. 


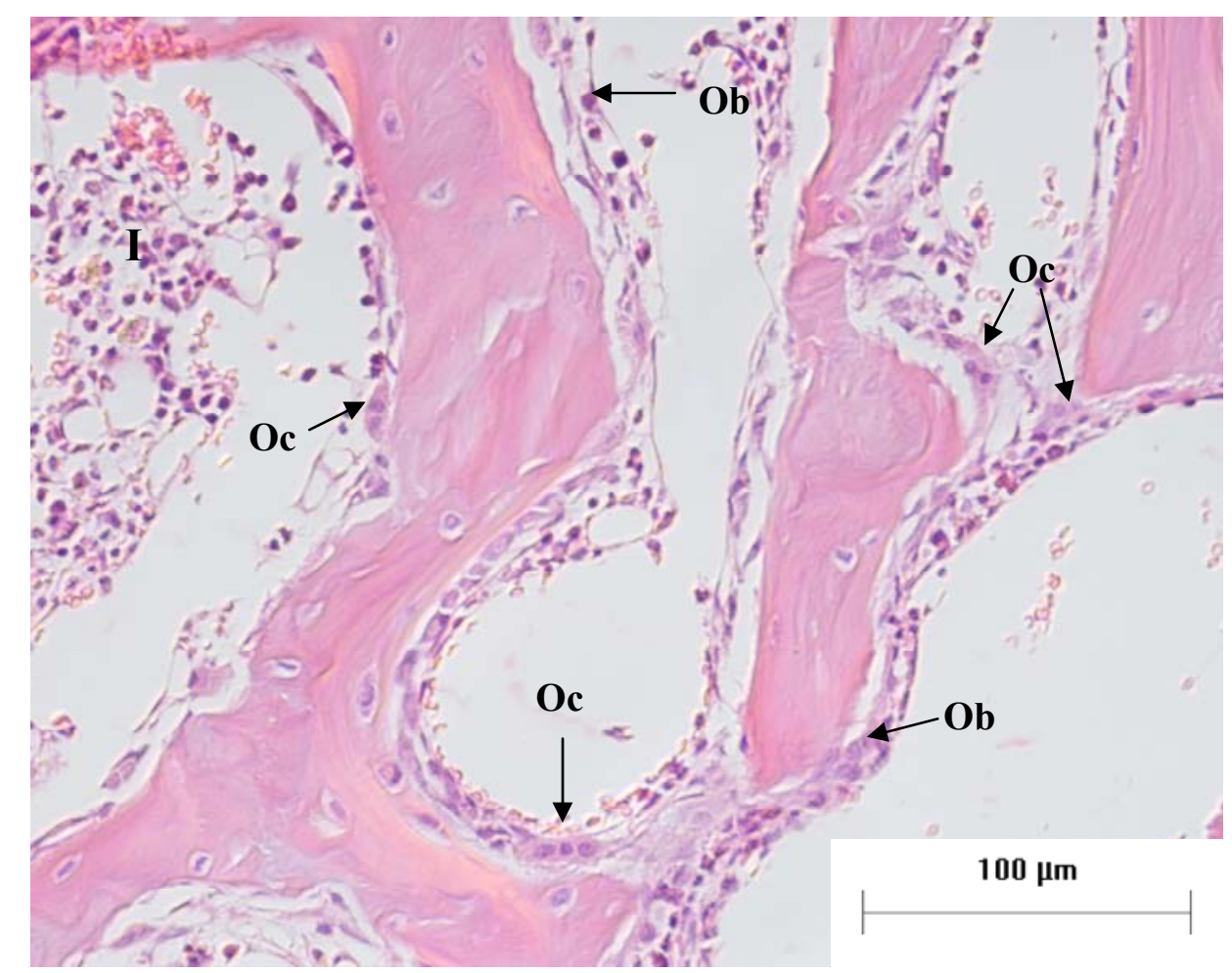

Figura 43 - Experimental 21 dias de pós-operatório. Notam-se osteoblastos (Ob) e osteoclastos (Oc) revestindo o trabeculado ósseo. Células inflamatórias (I) também são identificadas. Objetiva de 20x.

\section{8 dias de pós-operatório}

O grupo de animais com 28 dias de pós-operatório apresentou em seus alvéolos áreas ocupadas por fibroblastos com menor quantidade de células inflamatórias comparando-se ao período pós-operatório anterior. Aparentemente houve a diminuição da quantidade de osteoclastos, uma vez que poucos foram identificados. A união do enxerto ao osso neoformado foi evidente e o trabeculado ósseo apresentou-se mais espessado e organizado, revestido por osteoblastos e preenchendo a maior parte do alvéolo dental. Notam-se vasos sangüíneos penetrando os fragmentos de enxerto ósseo. Algumas áreas sem preenchimento ósseo ainda foram observadas (Figuras 44 a 47). 


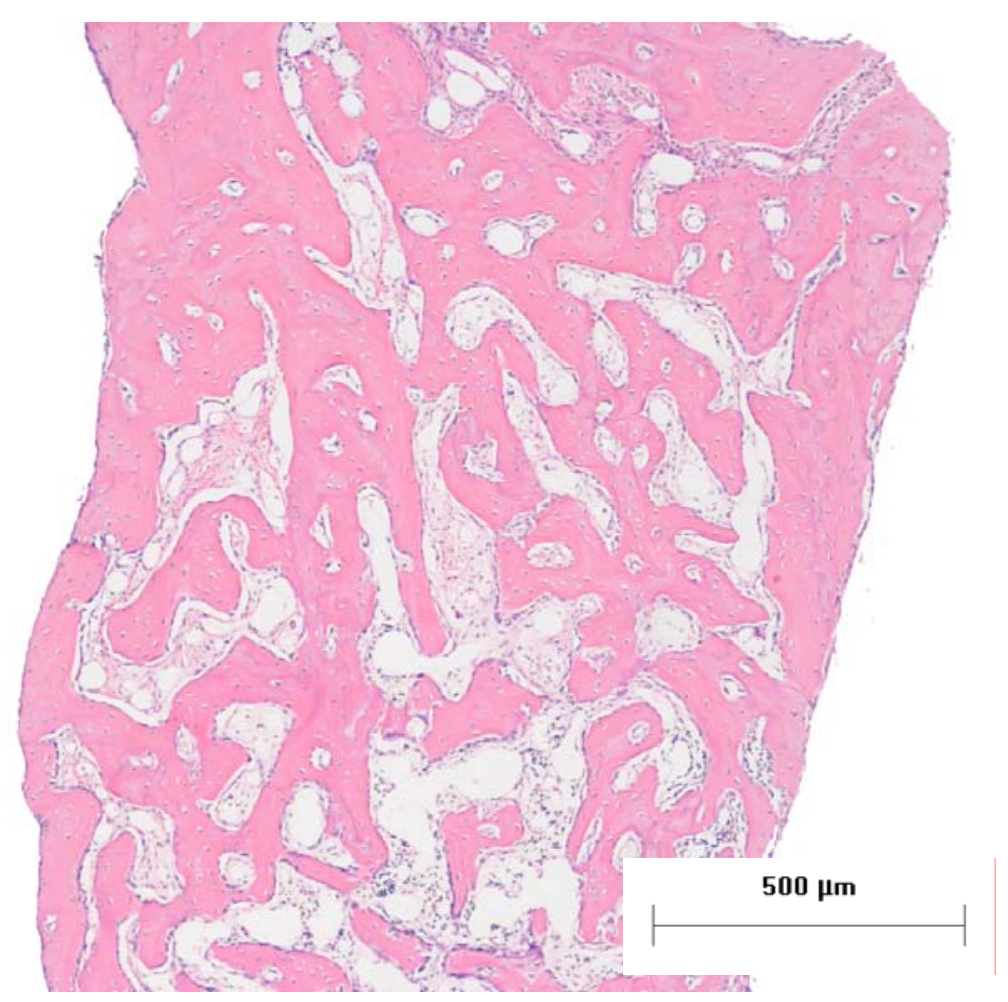

Figura 44 - Experimental 28 dias de pós-operatório. Observa-se o trabeculado ósseo organizado ocupando grande parte do alvéolo dental. Objetiva de 4x.

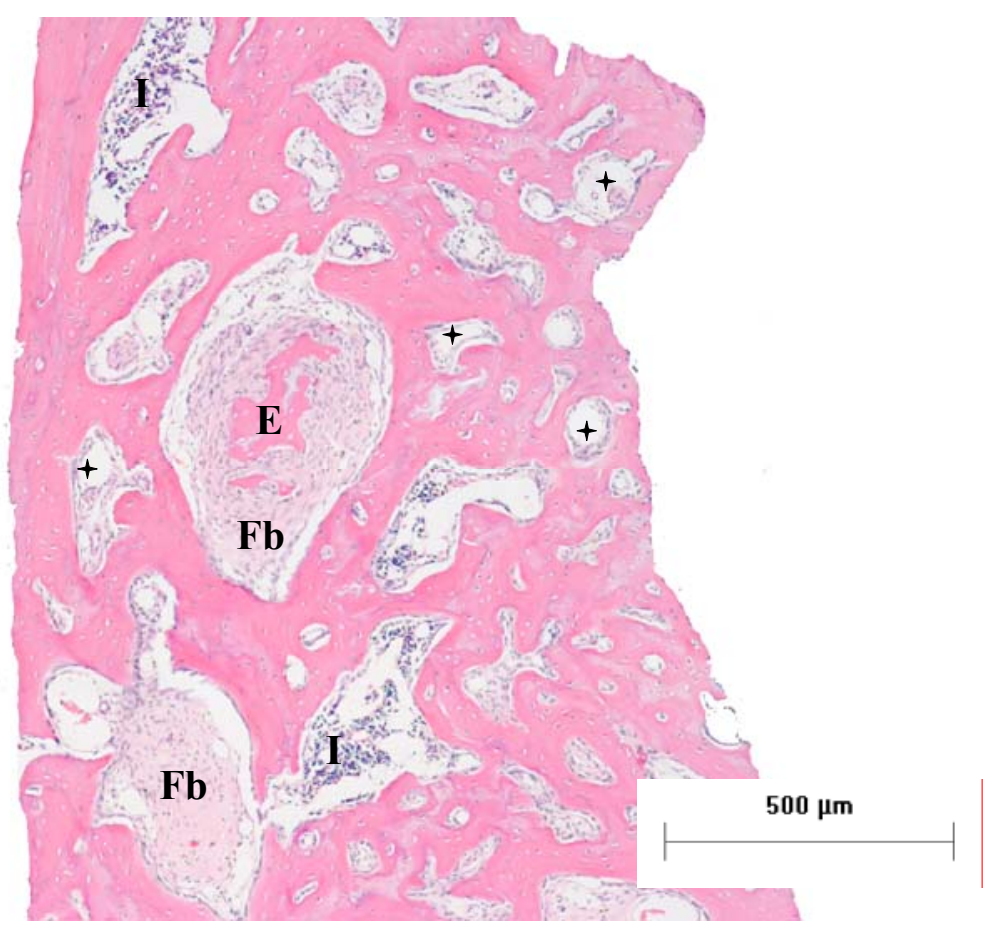

Figura 45 - Experimental 28 dias de pós-operatório. Observam-se algumas áreas sem preenchimento ósseo, ocupadas por fibroblastos ( Fb), células inflamatórias (I) e vasos sangüíneos ${ }^{+}$). Nota-se ainda um fragmento de enxerto (E) circundado por fibroblastos. Objetiva de $4 \mathrm{x}$. 


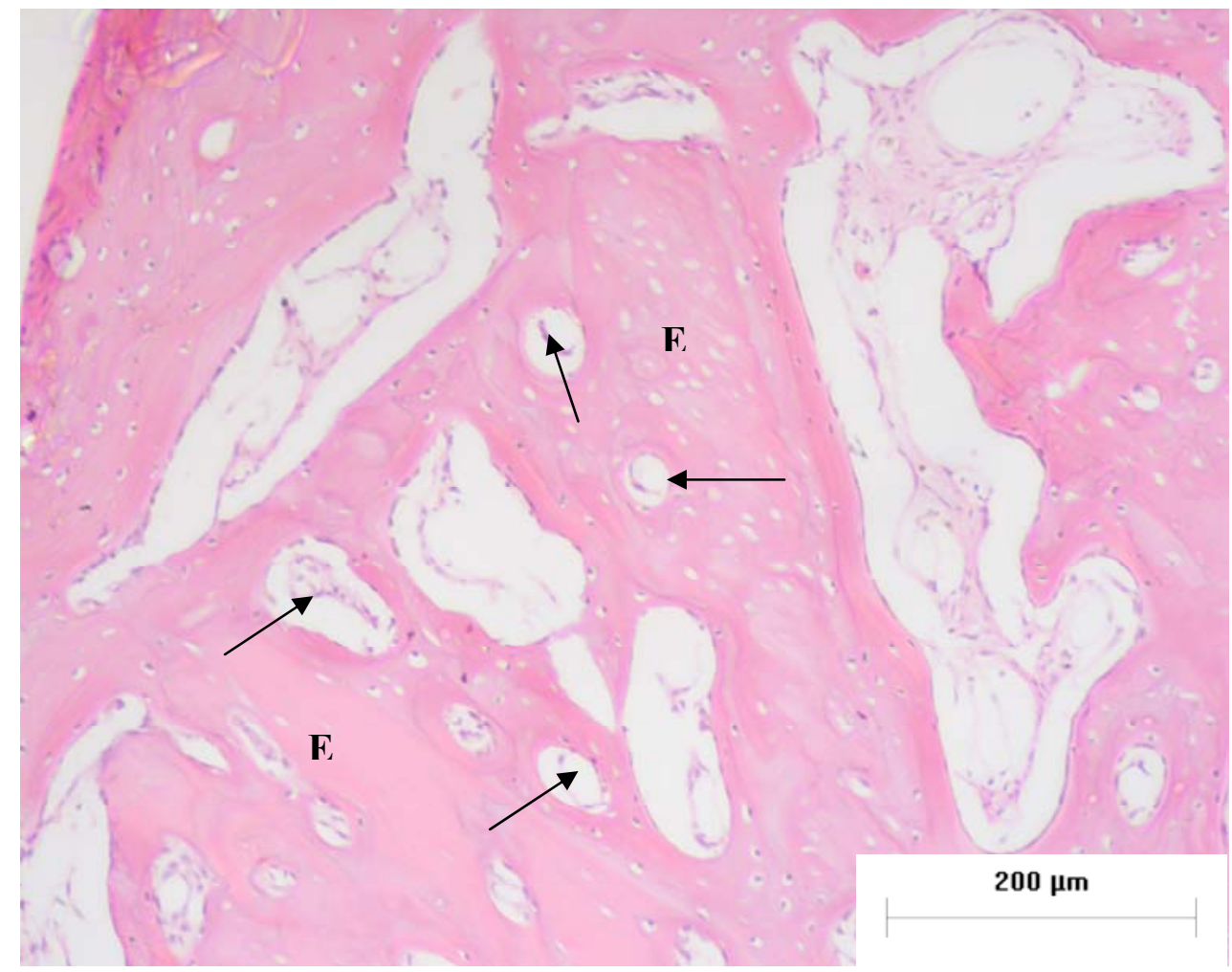

Figura 46 - Experimental 28 dias de pós-operatório. Identifica-se o enxerto ósseo (E) incorporado às trabéculas neoformadas e com penetração de vasos sangüíneos (setas).

Objetiva de 10x.

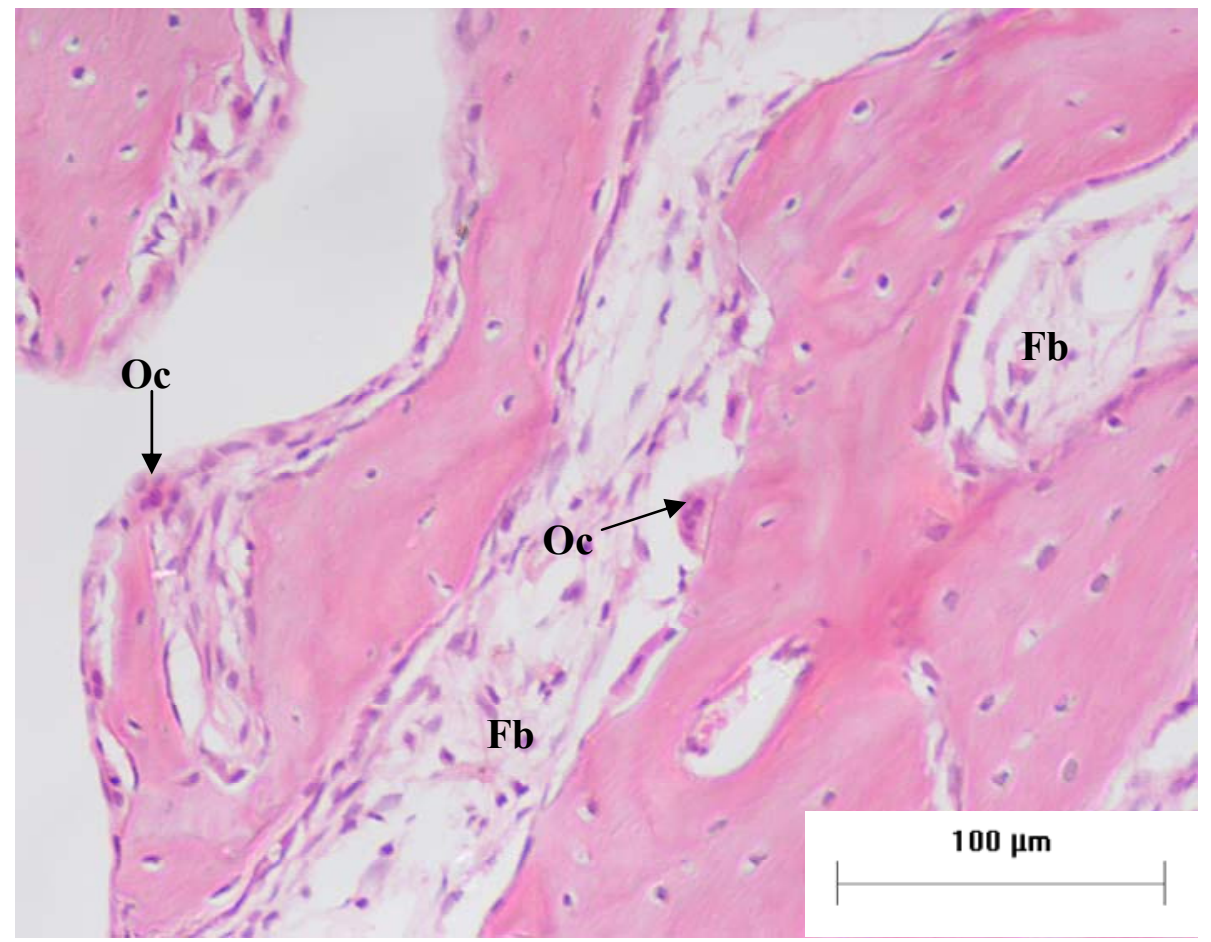

Figura 47 - Experimental 28 dias de pós-operatório. Notam-se osteoclastos (Oc) na superfície das trabéculas ósseas e espaços intertrabeculares amplos ocupados por fibroblastos $(\mathrm{Fb})$. Objetiva de 20x. 


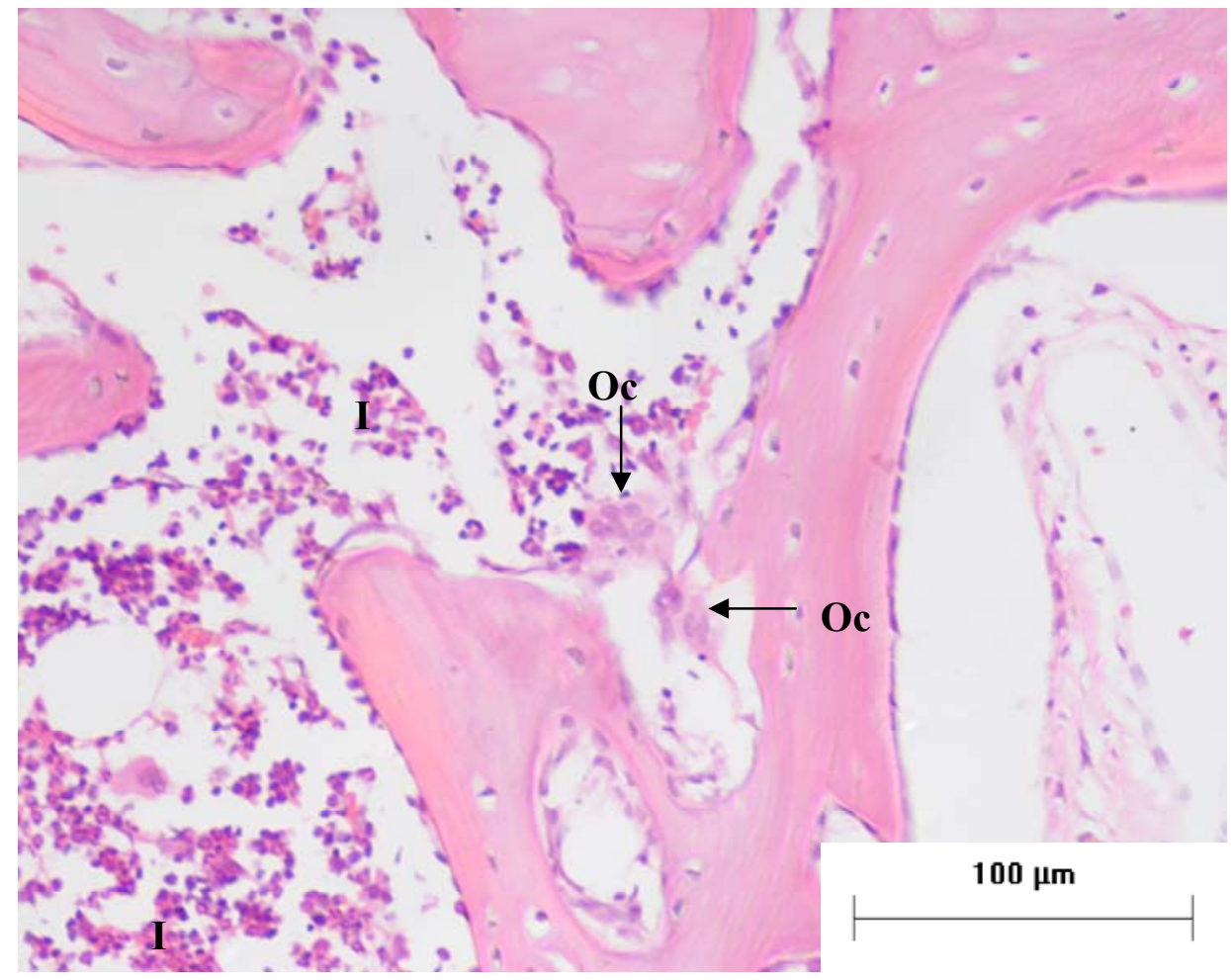

Figura 48 - Experimental 28 dias de pós-operatório. Observam-se osteoclastos (Oc) e células inflamatórias (I). Objetiva de 20x.

\subsection{ANÁLISE QUALITATIVA DOS CORTES HISTOLÓGICOS CORADOS COM PICROSÍRIUS OBSERVADOS EM MICROSCÓPIO SOB LUZ POLARIZADA}

\subsubsection{Grupo controle}

Em todos os períodos pós-operatórios, os cortes histológicos dos alvéolos dentais dos animais apresentaram predominantemente fibras com coloração laranja-amarelada, caracterizando o colágeno tipo I. Fibras com coloração esverdeada, característica do colágeno tipo III, também foram identificadas. Observou-se que houve um aumento progressivo das fibras colágenas de acordo com a evolução do tempo pós-operatório. No período de 28 dias de pós-operatório as fibras apresentavam-se mais organizadas e dispostas em forma de lamelas (Figuras 49 a 54). 


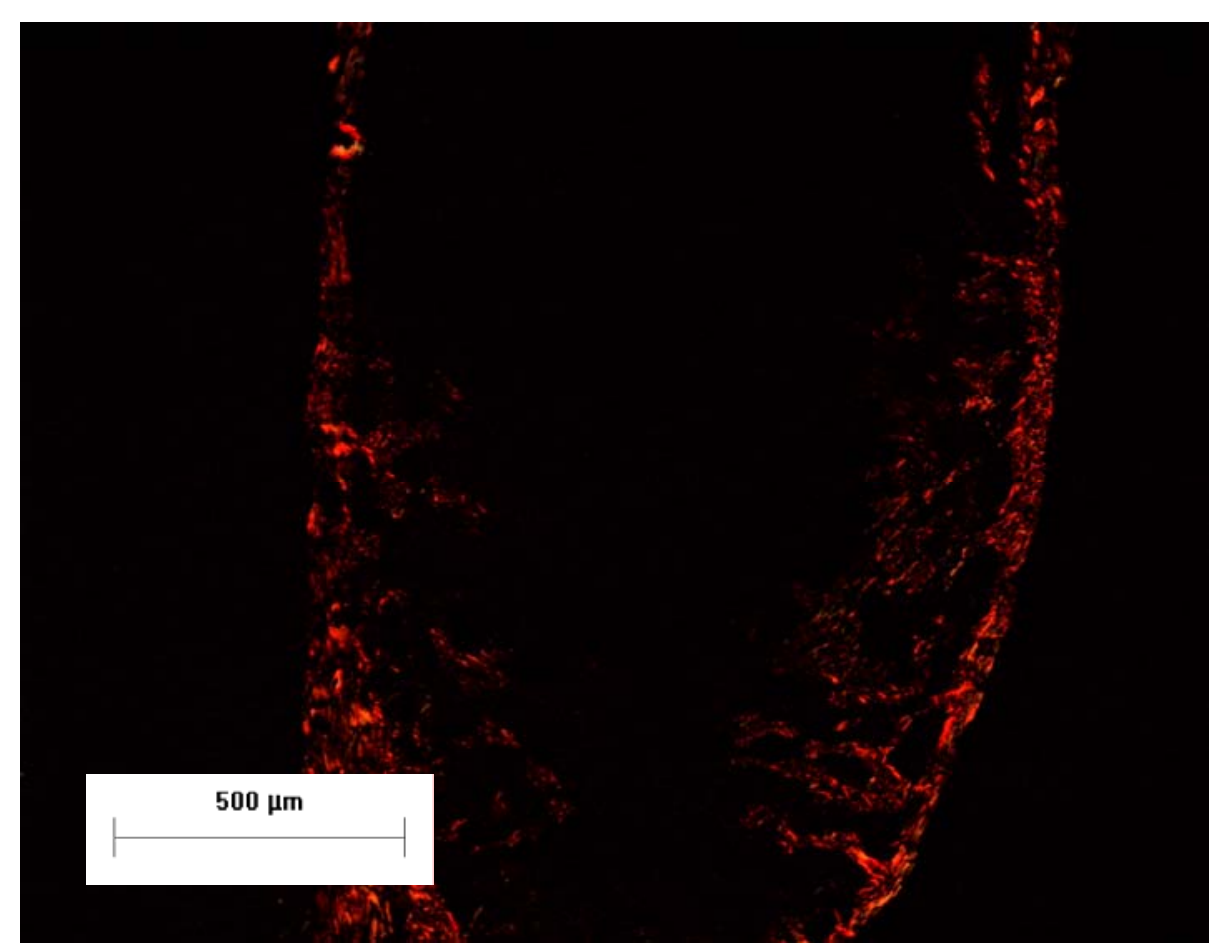

Figura 49 - Controle 5 dias de pós-operatório. Observa-se o predomínio de fibras colágenas do tipo I. Nota-se que os feixes de fibras colágenas são mais evidentes próximos as corticais ósseas do que ao centro do alvéolo dental. Objetiva de 4x.

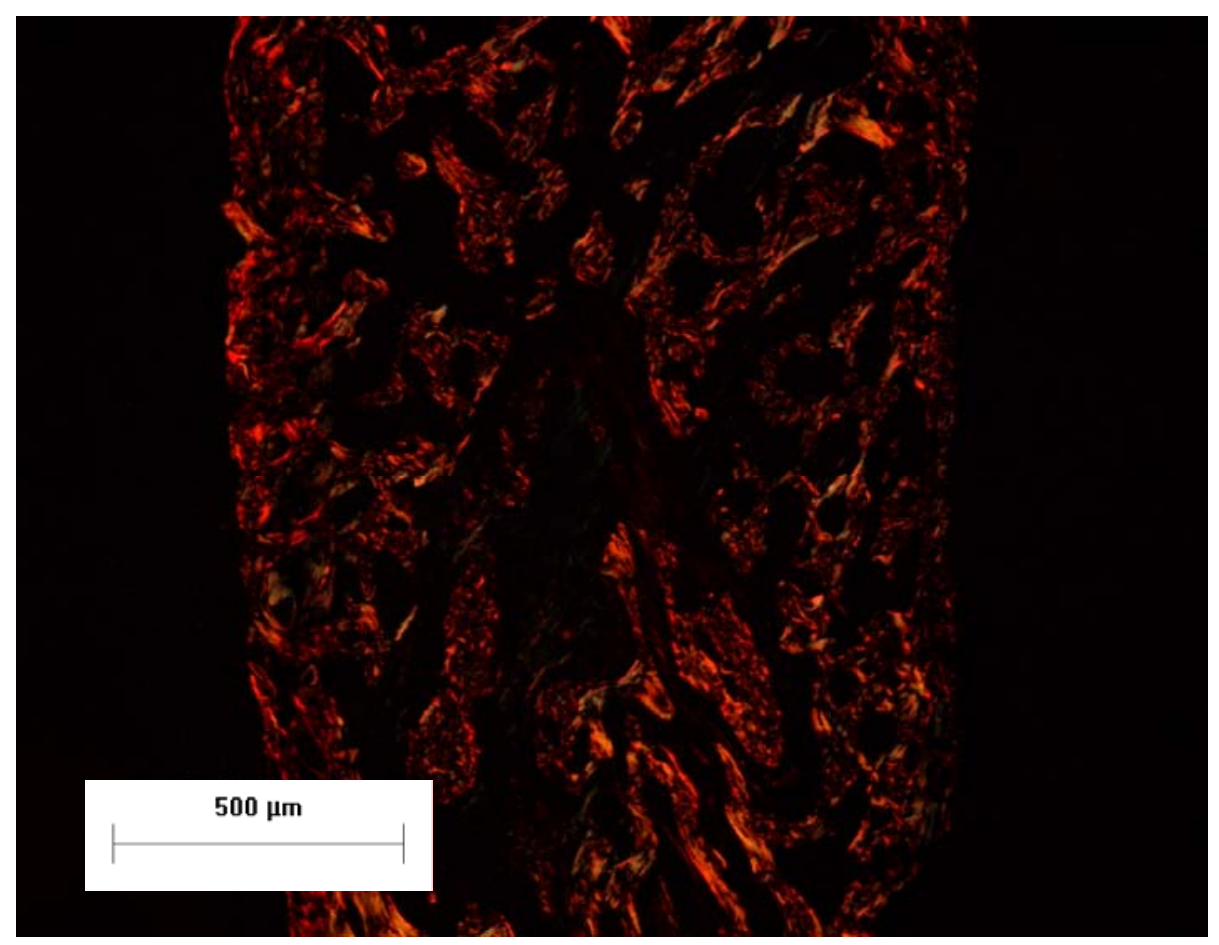

Figura 50 - Controle 15 dias de pós-operatório. Observa-se o predomínio de fibras colágenas do tipo I. Nota-se que os feixes de fibras colágenas ocupam grande parte do alvéolo dental e estão mais espessos e organizados. Objetiva de $4 \mathrm{x}$. 


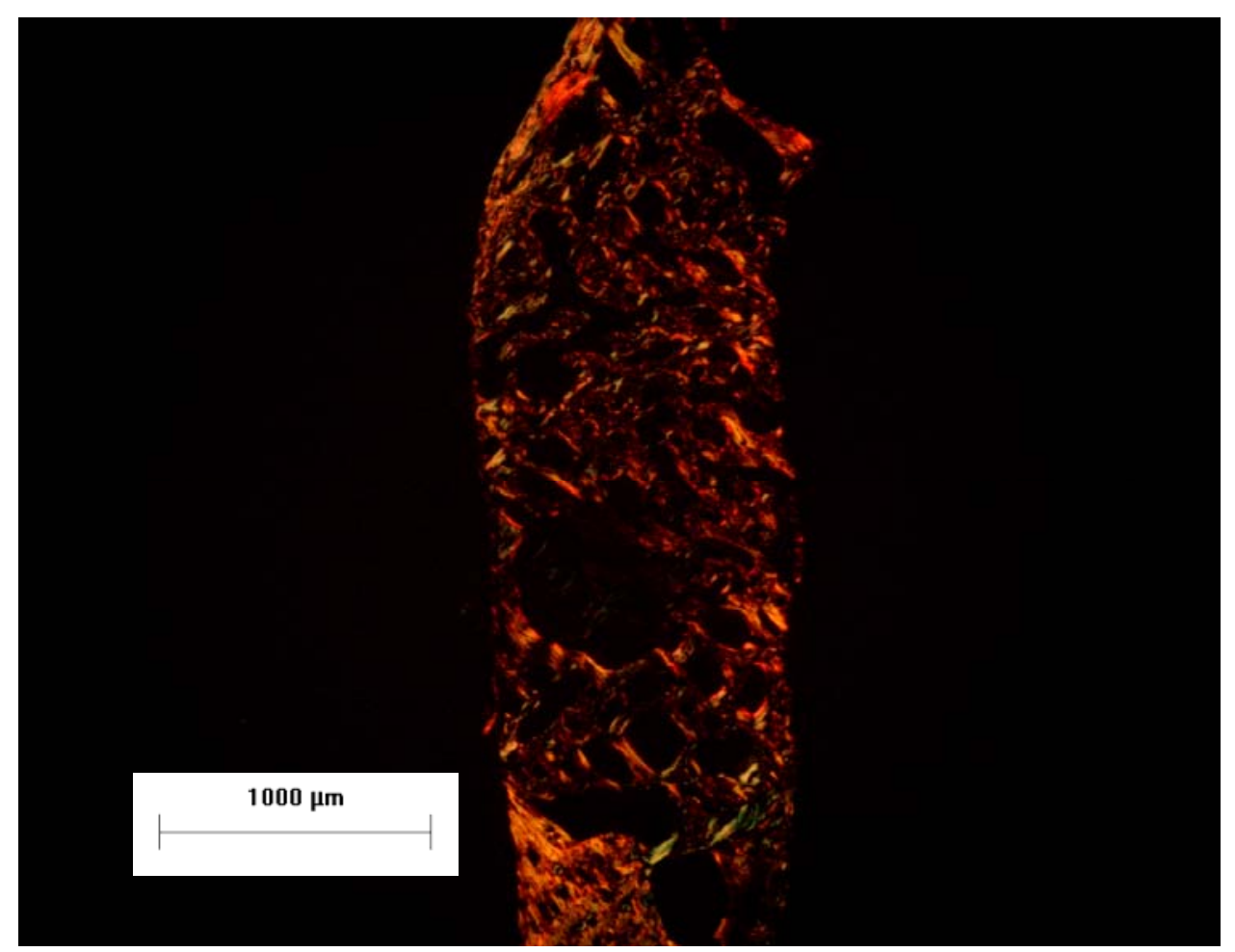

Figura 51 - Controle 21 dias de pós-operatório. Observa-se o predomínio de fibras colágenas do tipo I, ocupando uma extensa área do alvéolo dental. Objetiva de 2x.

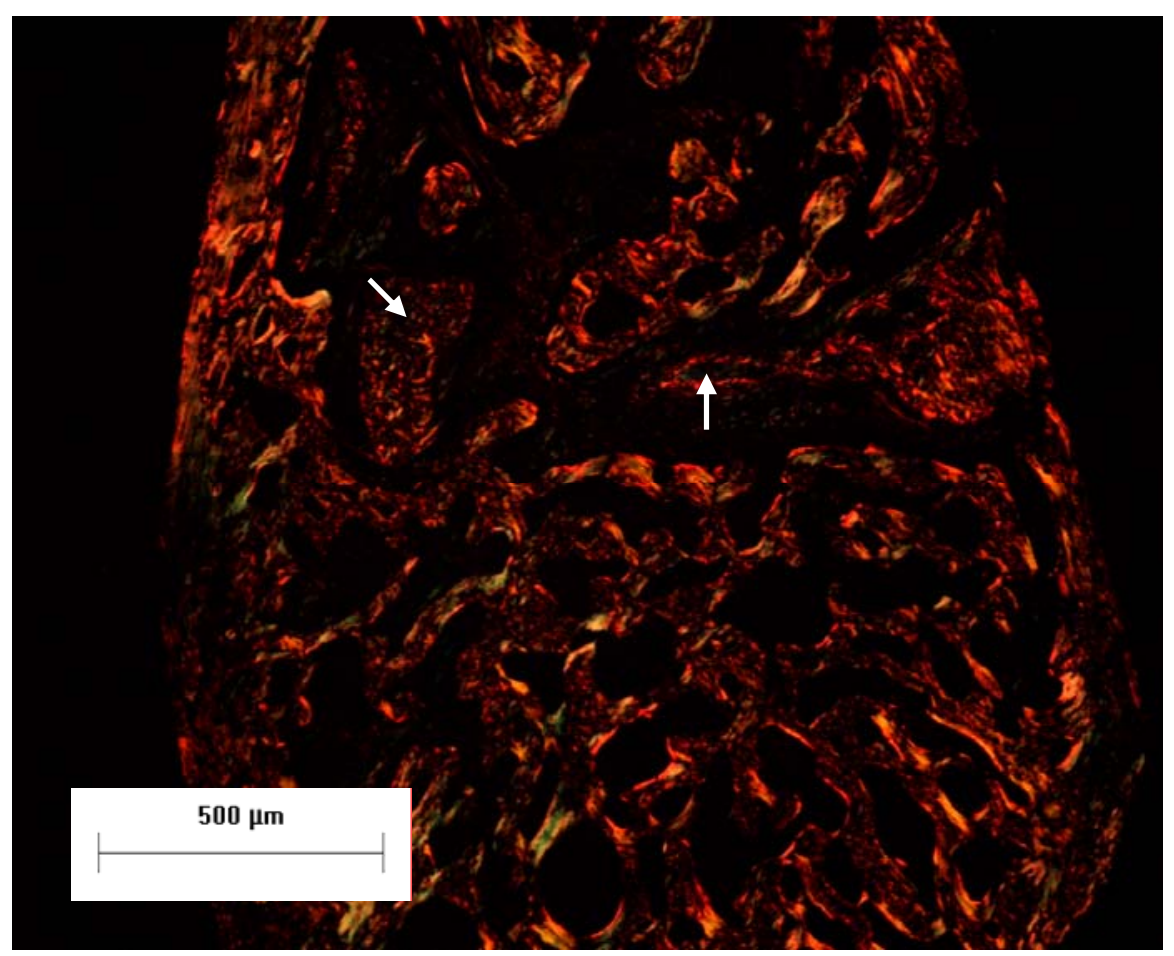

Figura 52 - Controle 21 dias de pós-operatório. Observa-se o predomínio de fibras colágenas do tipo I. Notam-se ainda áreas com feixes de fibras colágenas desorganizadas (Setas). Objetiva de 4x. 


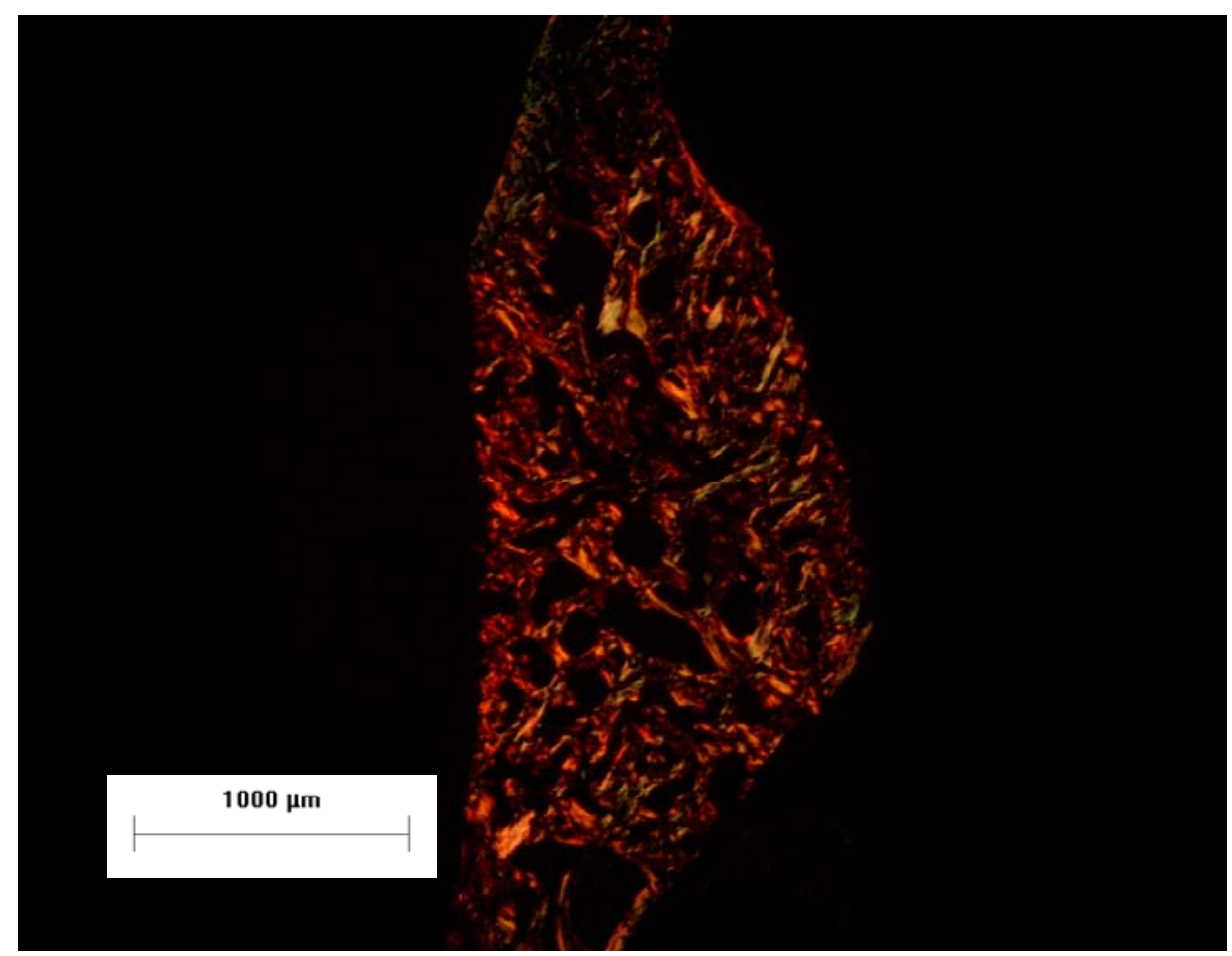

Figura 53 - Controle 28 dias de pós-operatório. Observa-se o predomínio de fibras colágenas do tipo I. Os feixes de fibras colágenas das trabéculas ósseas encontram-se organizadas e distribuídas por todo alvéolo dental. Objetiva de 2x.

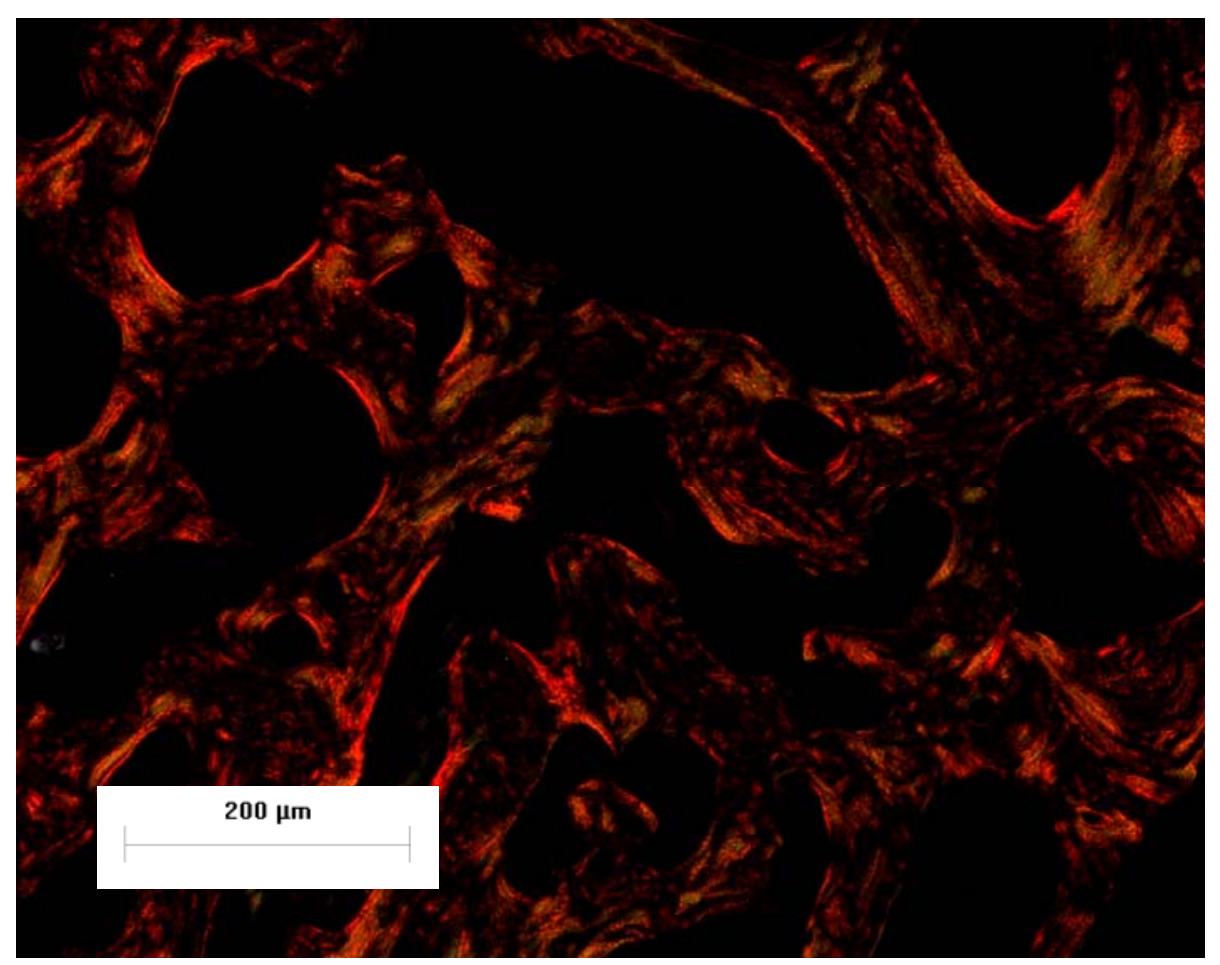

Figura 54 - Controle 28 dias de pós-operatório. Observa-se o predomínio de fibras colágenas do tipo I e a organização em forma de lamelas das fibras. Objetiva de 10x. 


\subsubsection{Grupo experimental}

Os cortes histológicos dos alvéolos dentais dos animais apresentaram o predomínio de fibras colágenas do tipo I em relação ao colágeno tipo III. Entretanto, a proporção de colágeno tipo III nos ratos experimentais foi aparentemente maior do que nos ratos controles. Observou-se que alguns fragmentos de enxerto ósseo apresentavam predominantemente colágeno tipo III, enquanto em outros fragmentos predominava o colágeno tipo I. O aumento progressivo de fibras colágenas no decorrer dos períodos pós-operatórios foi observado, de maneira semelhante ao grupo controle (Figuras 55 a 62).

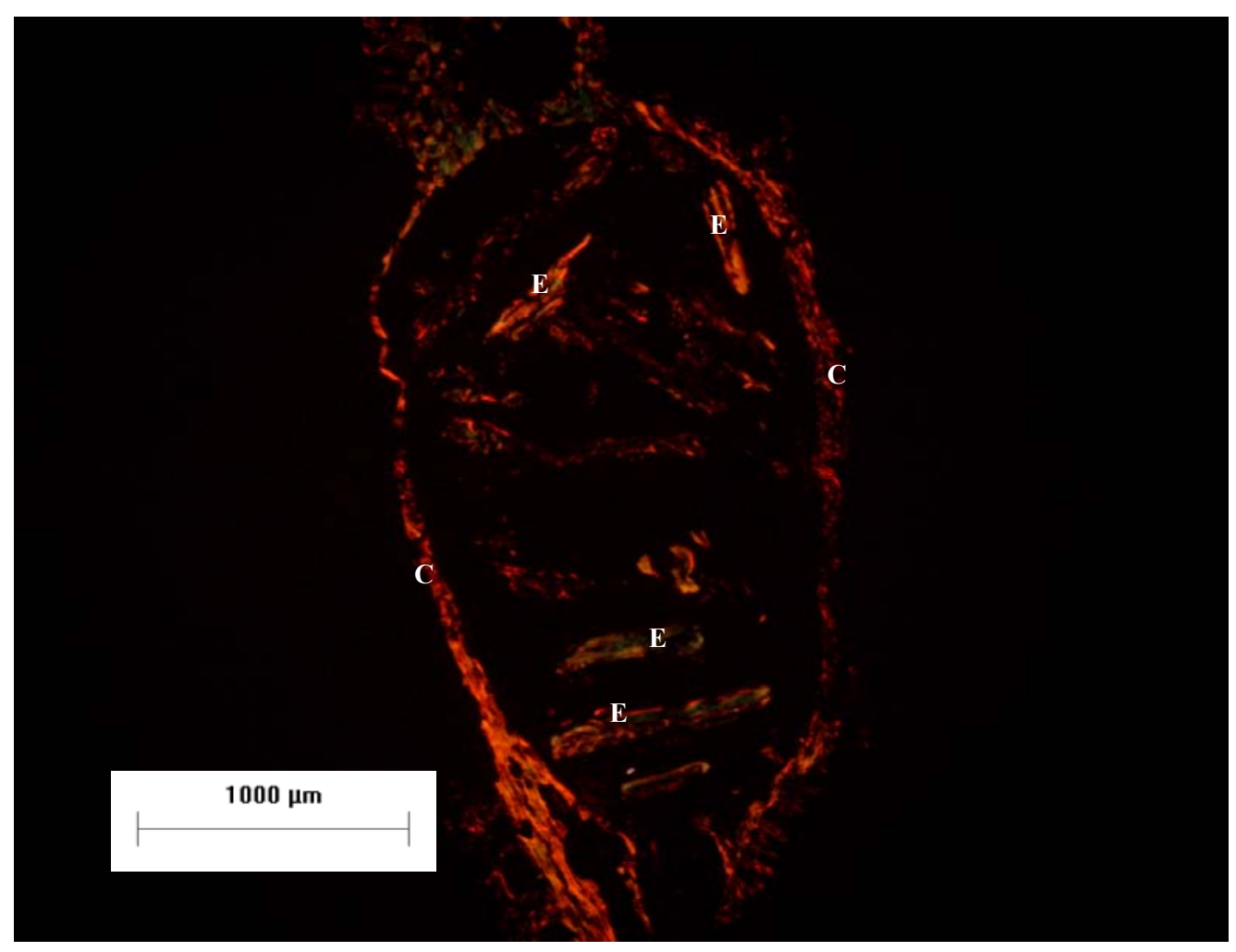

Figura 55 - Experimental 5 dias de pós-operatório. Observa-se o predomínio de fibras colágenas do tipo I nas corticais alveolares (C) e em alguns fragmentos de enxerto (E).

Outros fragmentos predominam o colágeno tipo III. Objetiva de $2 \mathrm{x}$. 


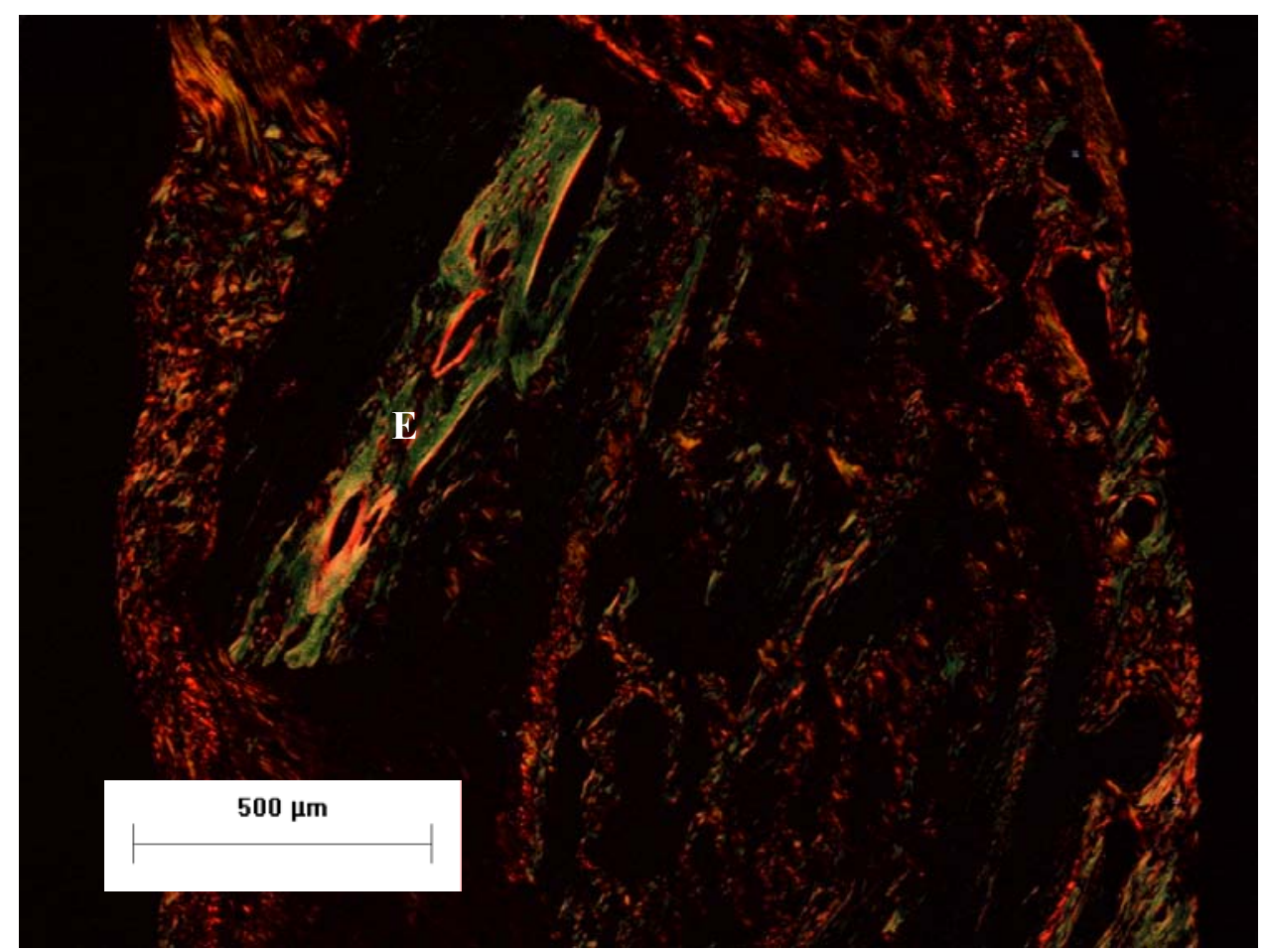

Figura 56 - Experimental 5 dias de pós-operatório. Observa-se em um maior aumento o predomínio do colágeno tipo III em um fragmento de enxerto ósseo (E). Objetiva de 4x.

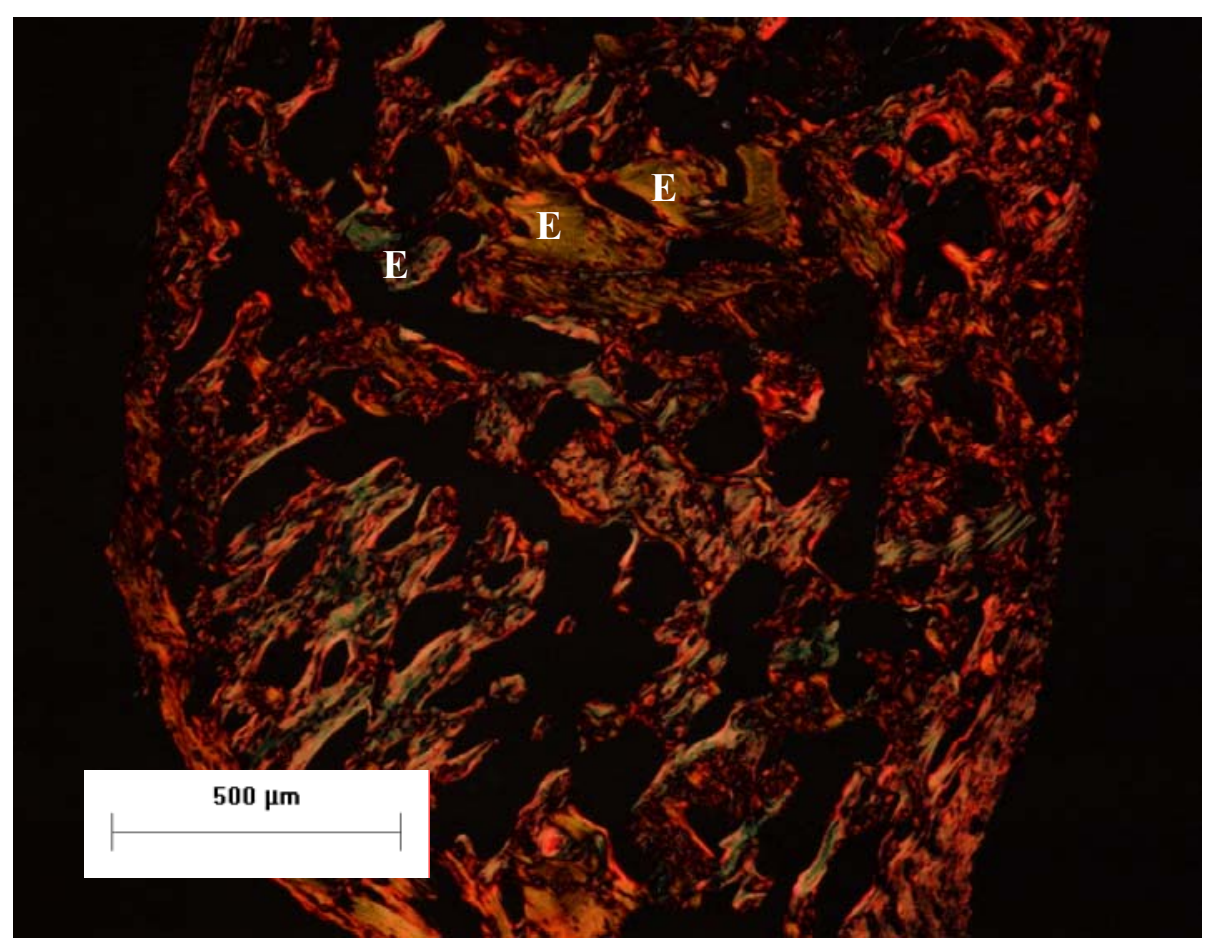

Figura 57 - Experimental 15 dias de pós-operatório. Observa-se a disposição dos feixes de fibras colágenas tipos I e III. Nota-se a integração do enxerto (E) com o osso neoformado. Objetiva de 4x. 


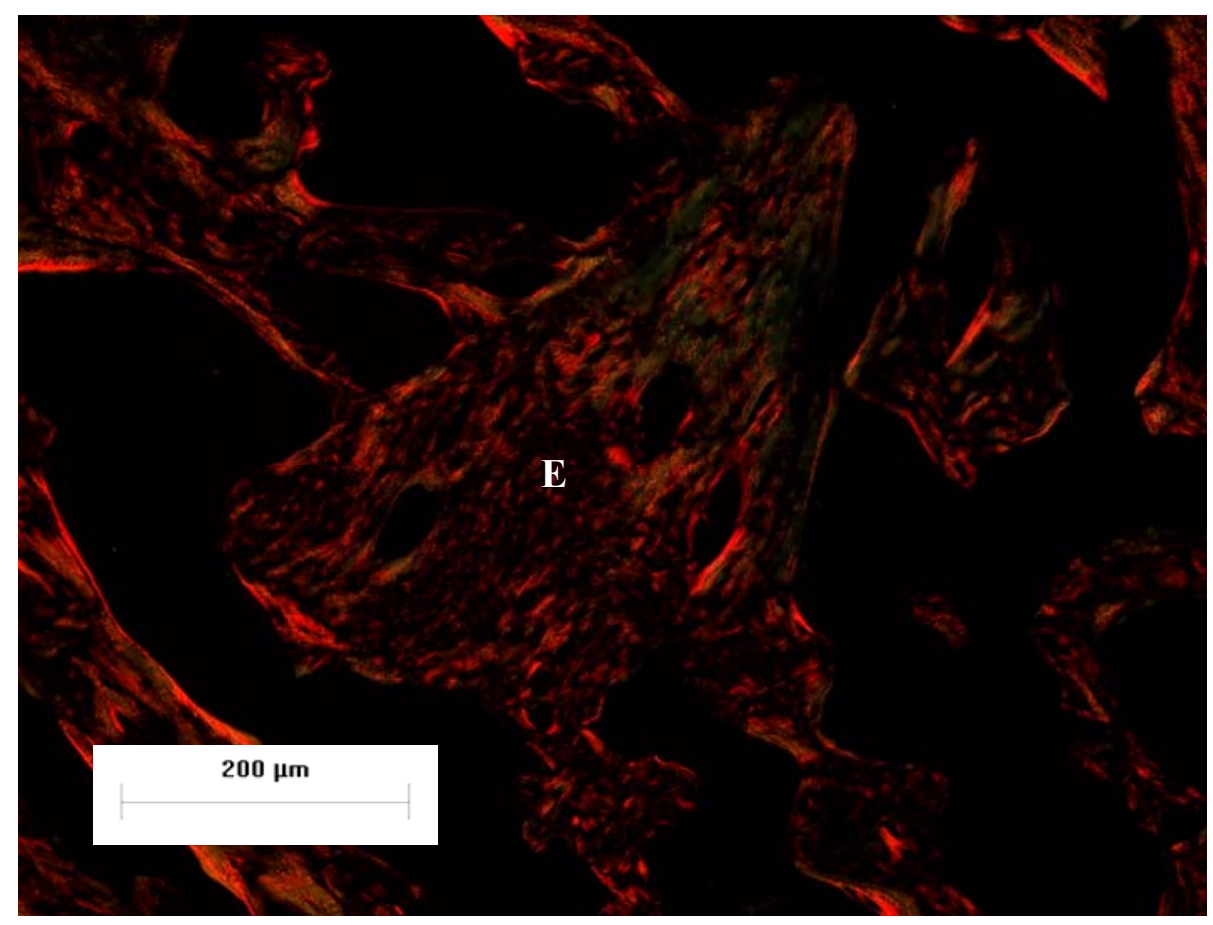

Figura 58 - Experimental 15 dias de pós-operatório. Nota-se o predomínio de fibras colágenas do tipo I. Observa-se em um maior aumento a união de um fragmento de enxerto (E) ao osso neoformado. Objetiva de 10x.

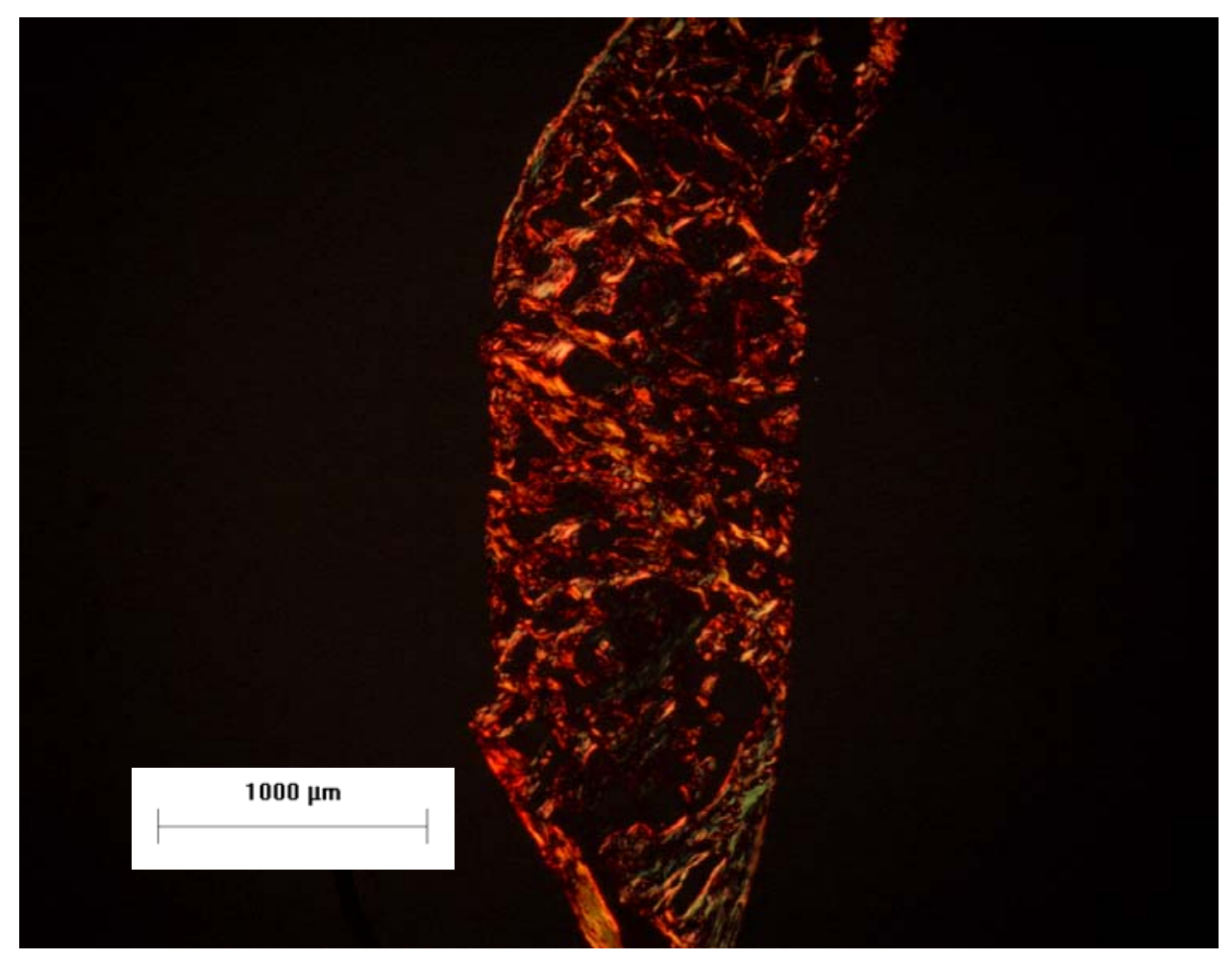

Figura 59 - Experimental 21 dias de pós-operatório. Observa-se o predomínio de fibras colágenas do tipo I ocupando grande parte do alvéolo dental. Objetiva de 2x. 


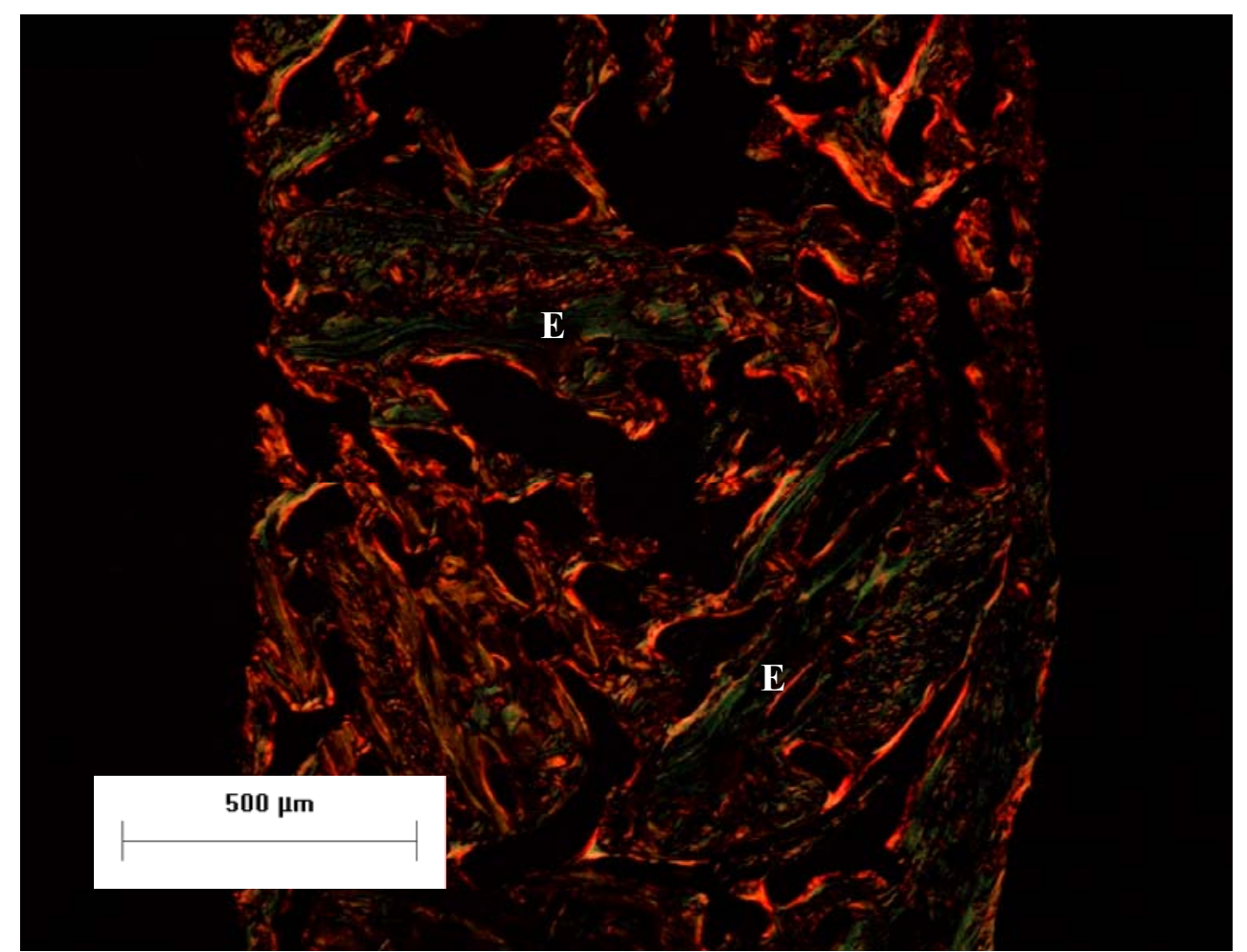

Figura 60 - Experimental 21 dias de pós-operatório. Observam-se fragmentos de enxerto ósseo (E) com predomínio de fibras colágenas do tipo III. Objetiva de 4x.

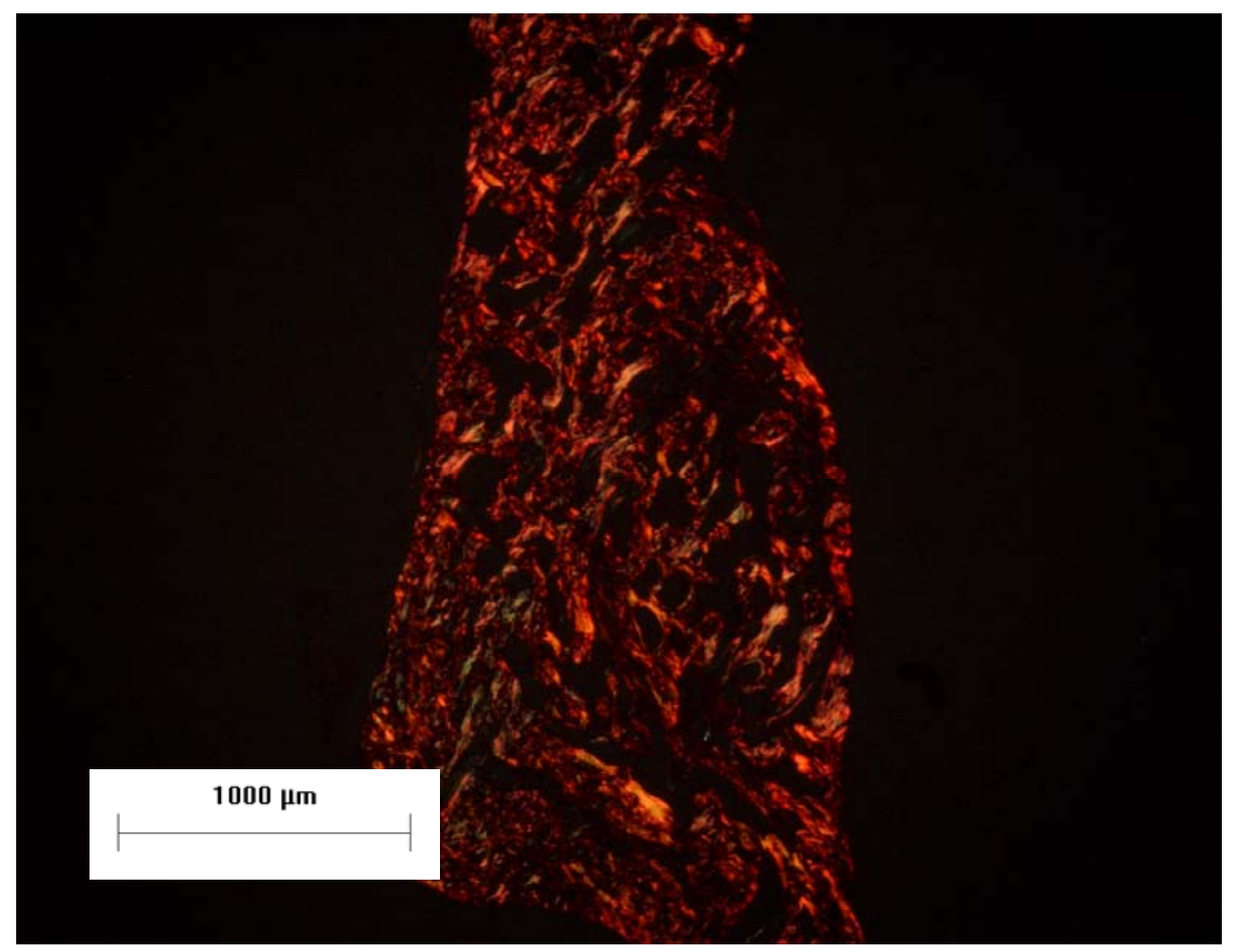

Figura 61 - Experimental 28 dias de pós-operatório. Nota-se o predomínio de fibras colágenas do tipo I. Objetiva de $2 x$. 


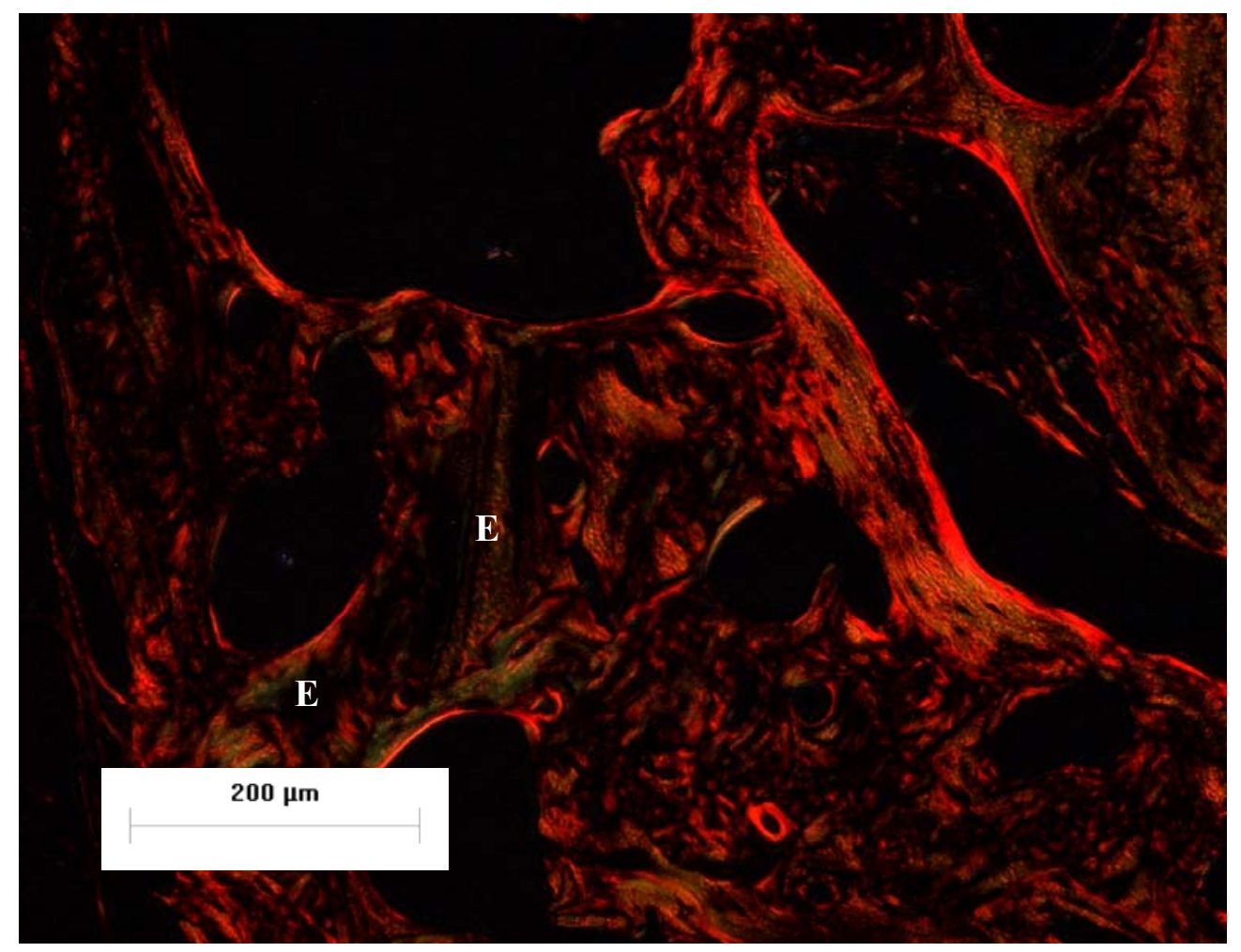

Figura 62 - Experimental 28 dias de pós-operatório. Observa-se a disposição em forma de lamelas dos feixes de fibras colágenas e a integração do enxerto ósseo (E) com as trabéculas ósseas neoformadas. Objetiva de 10x.

\subsection{ANÁLISE QUALITATIVA DOS CORTES HISTOLÓGICOS DOS ALVÉOLOS DENTAIS DOS RATOS QUE RECEBERAM CALCEÍNA OBSERVADOS EM MICROSCÓPIO SOB LUZ FLUORESCENTE}

A observação das cortes histológicos mostrou áreas de deposição mineral nos grupos controle e enxertado, evidenciada pelo marcador de ossificação calceína. Sob a luz fluorescente, a calceína apresentou-se na cor verde. Observaram-se claramente as linhas de deposição óssea periódica referente às aplicações de calceína realizadas semanalmente nos animais, durante o tempo de atividade do marcador (Figura 63).

Os animais controle apresentaram formação óssea que ocupa grande extensão do alvéolo, permanecendo algumas áreas sem preenchimento ósseo e em processo de mineralização (Figura 64). A figura 65 permite observar a maturação do trabeculado ósseo que se apresenta bem organizado. 


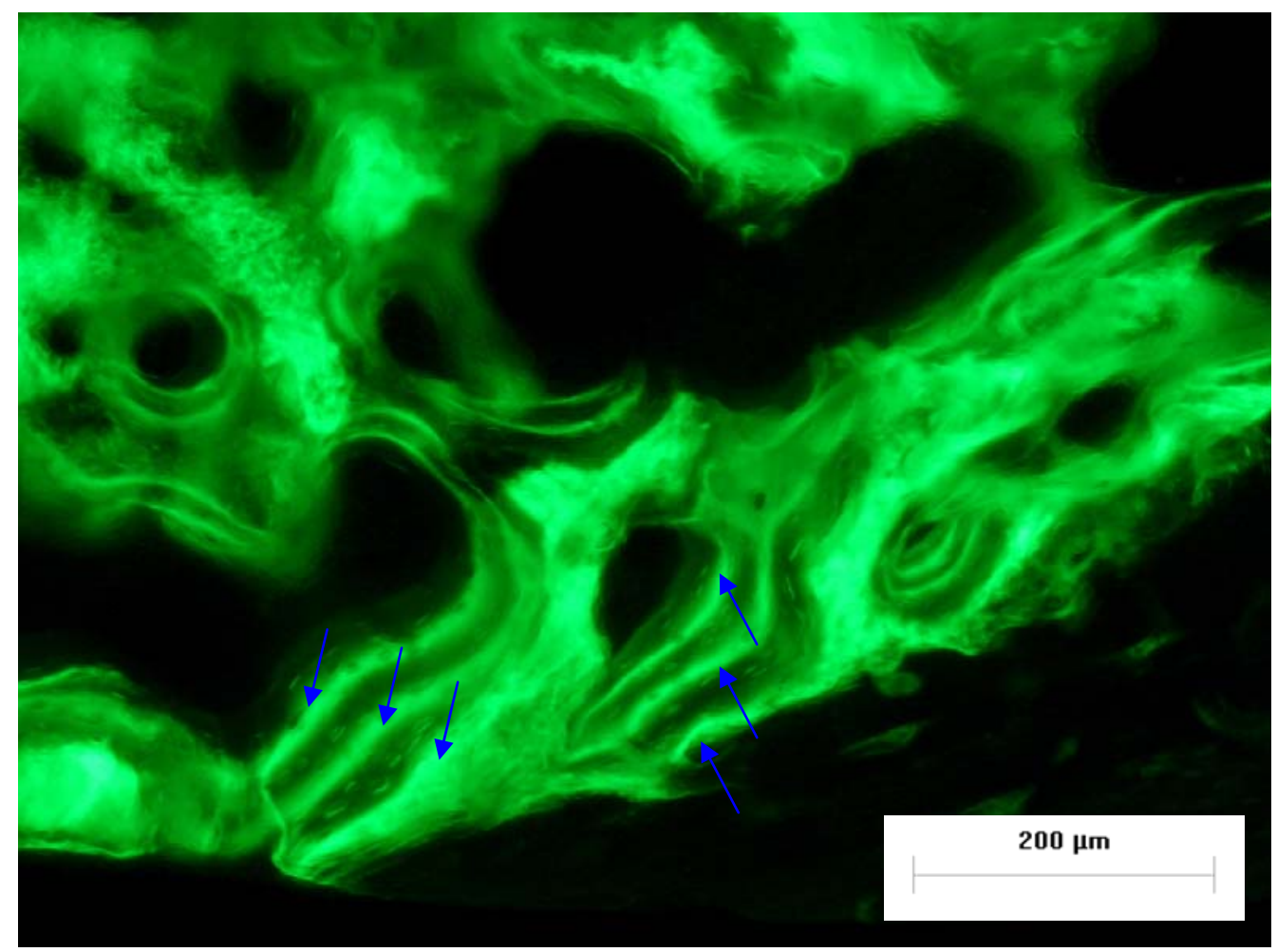

Figura 63 - Linhas de deposição mineral periódica marcadas pela calceína que evidenciam o processo de ossificação do alvéolo dental (setas). Objetiva de 10x.

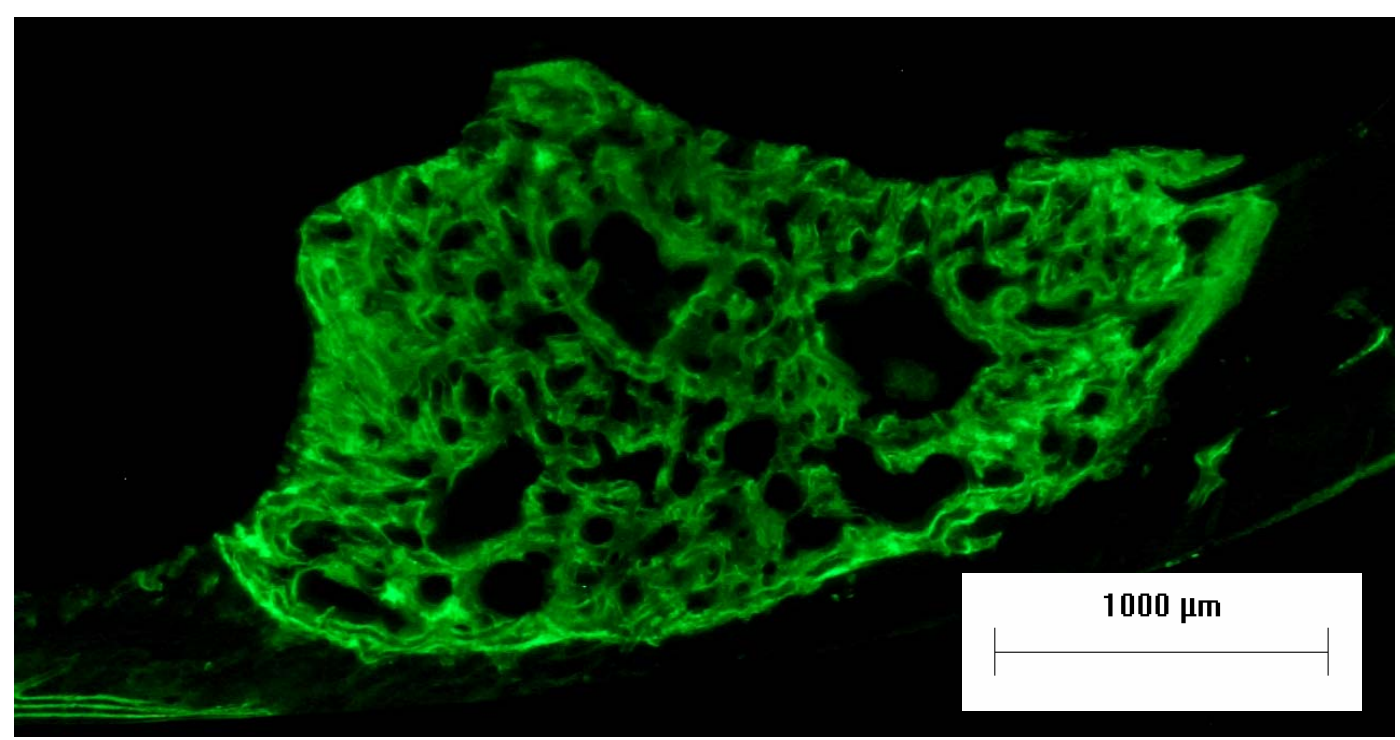

Figura 64 - Controle fluorescência. Observa-se o trabeculado ósseo preenchendo toda extensão do alvéolo dental com alguns espaços sem formação óssea. Objetiva $2 \mathrm{x}$. 


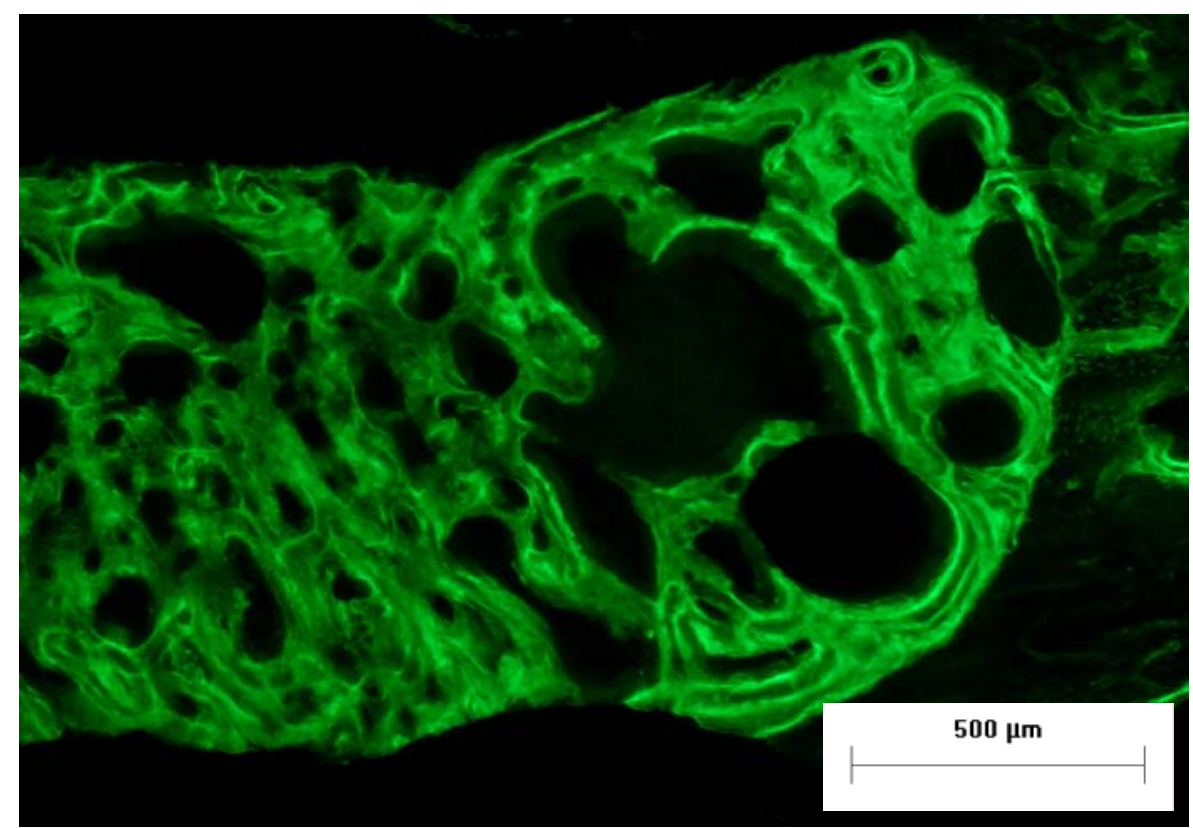

Figura 65 - Controle Fluorescência. Nota-se o trabeculado ósseo bem organizado. Objetiva 4x.

Os alvéolos dentais dos animais do grupo experimental mostraram trabéculas ósseas bem definidas preenchendo toda a extensão do alvéolo, com alguns espaços sem ossificação (Figura 66). Fragmentos de enxerto unidos às trabéculas ósseas, formando linhas de deposição mineral ao redor dos fragmentos, também foram observados (Figura 67). 


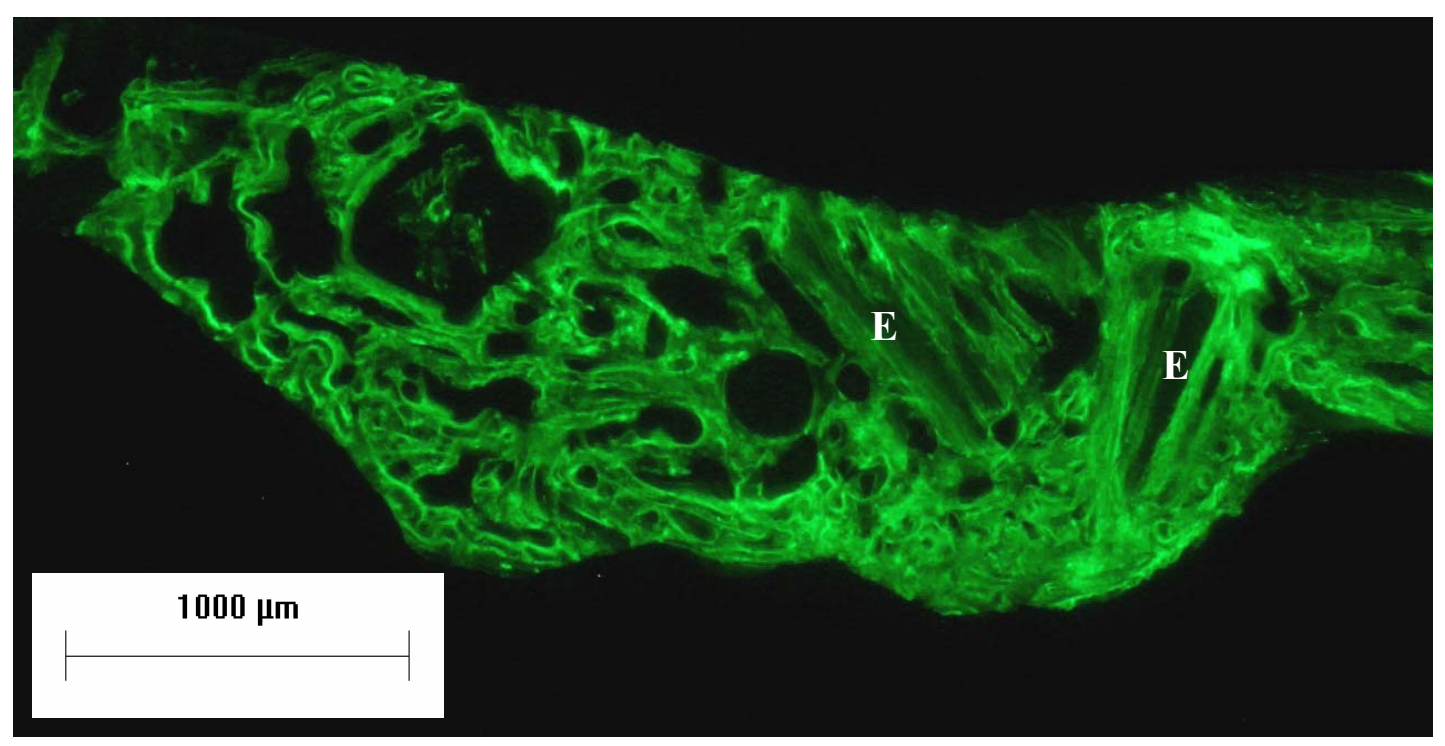

Figura 66 - Experimental fluorescência. Observa-se o preenchimento ósseo em grande parte do alvéolo dental com algumas áreas sem formação de osso. Os fragmentos de enxerto ósseo (E) estão integrados com as trabéculas ósseas neoformadas. Objetiva 2x.

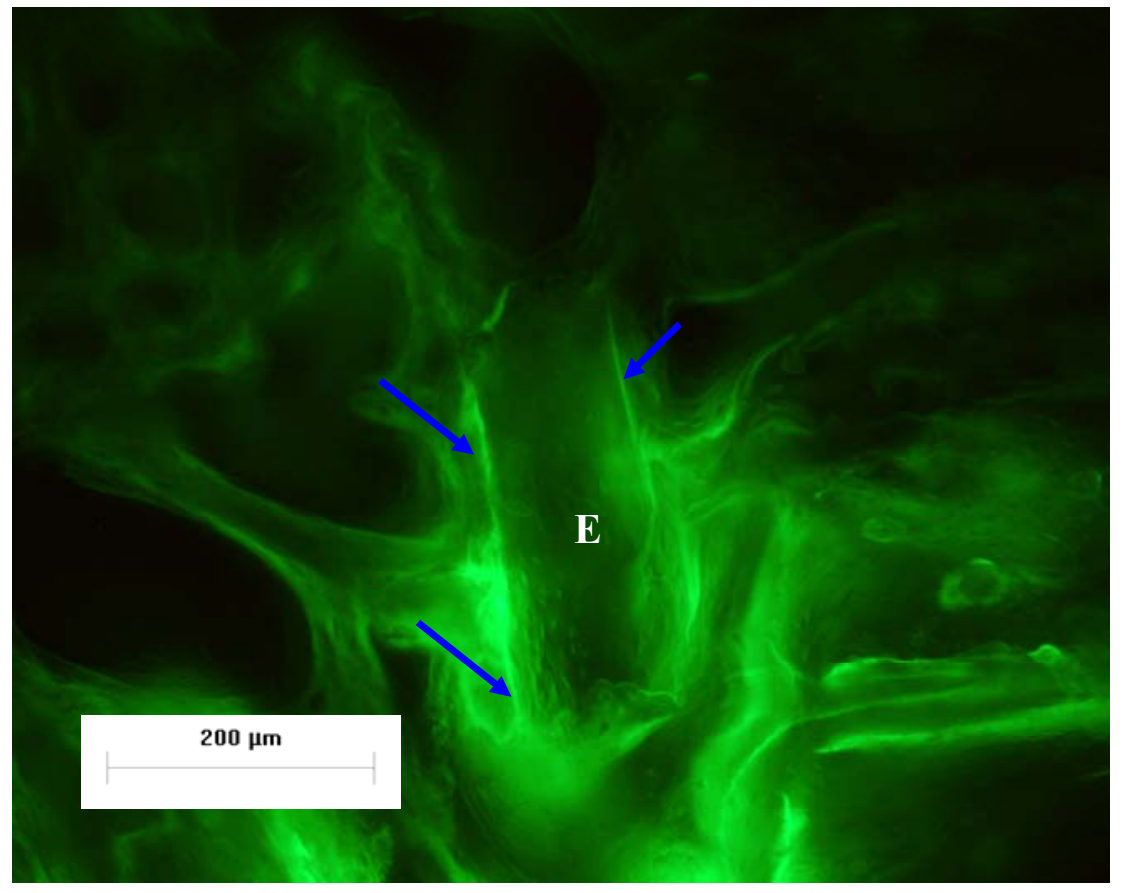

Figura 67 - Experimental fluorescência. Observa-se uma linha de deposição mineral (setas) ao redor do fragmento de enxerto ósseo (E). Objetiva 10x.

Linhas de deposição mineral sobre o processo alveolar são observadas, evidenciando a formação óssea extra-alveolar concomitante à formação de osso intra-alveolar (Figura 68). 


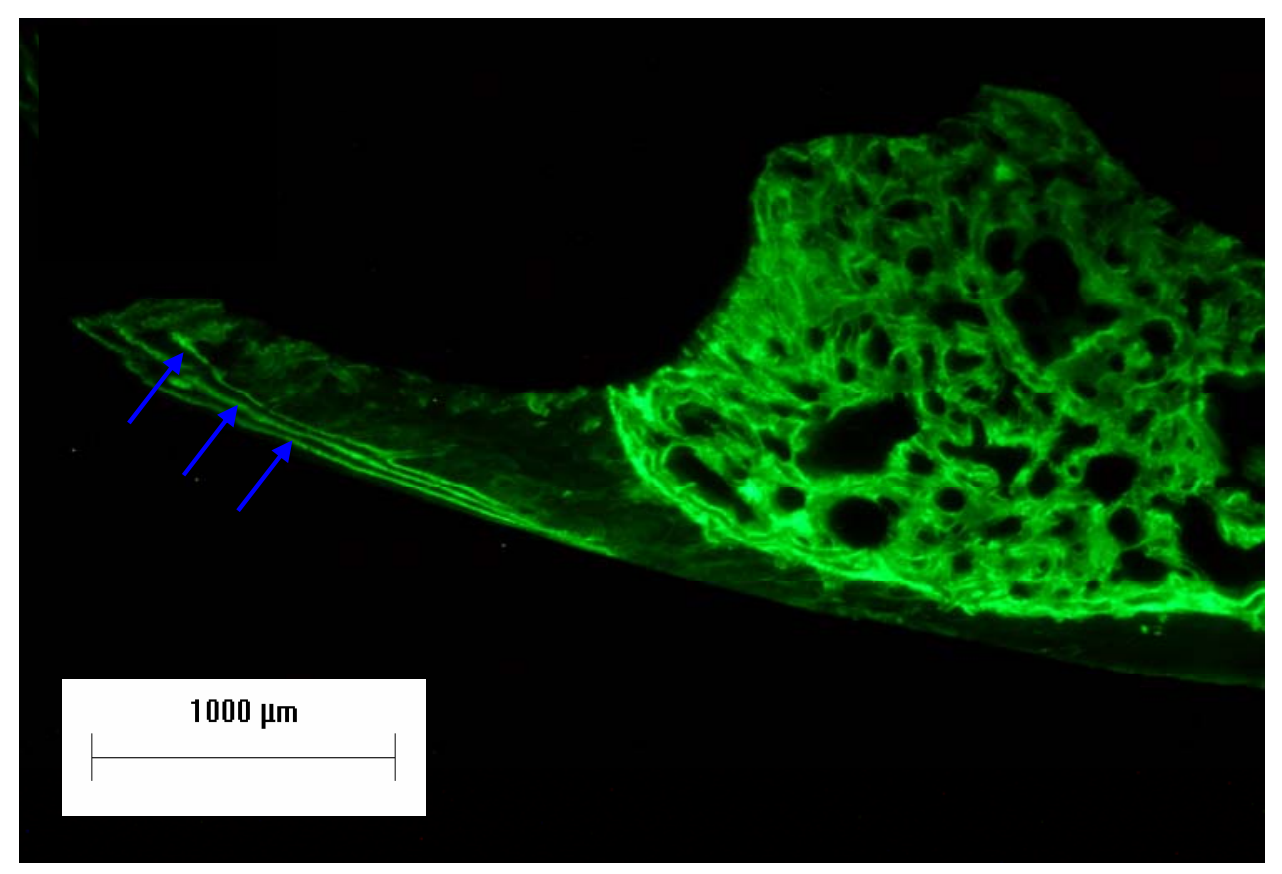

Figura 68 - Experimental fluorescência. Observam-se as linhas de deposição mineral sobre a cortical do processo alveolar (setas). Objetiva $2 \mathrm{x}$.

\subsection{ANÁLISE QUANTITATIVA}

Os resultados da morfometria da média das densidades de área ocupadas por osso nos alvéolos dentais dos grupos controle e experimental, realizados pela contagem diferencial de pontos com auxílio do sistema teste, estão expostos a seguir: 


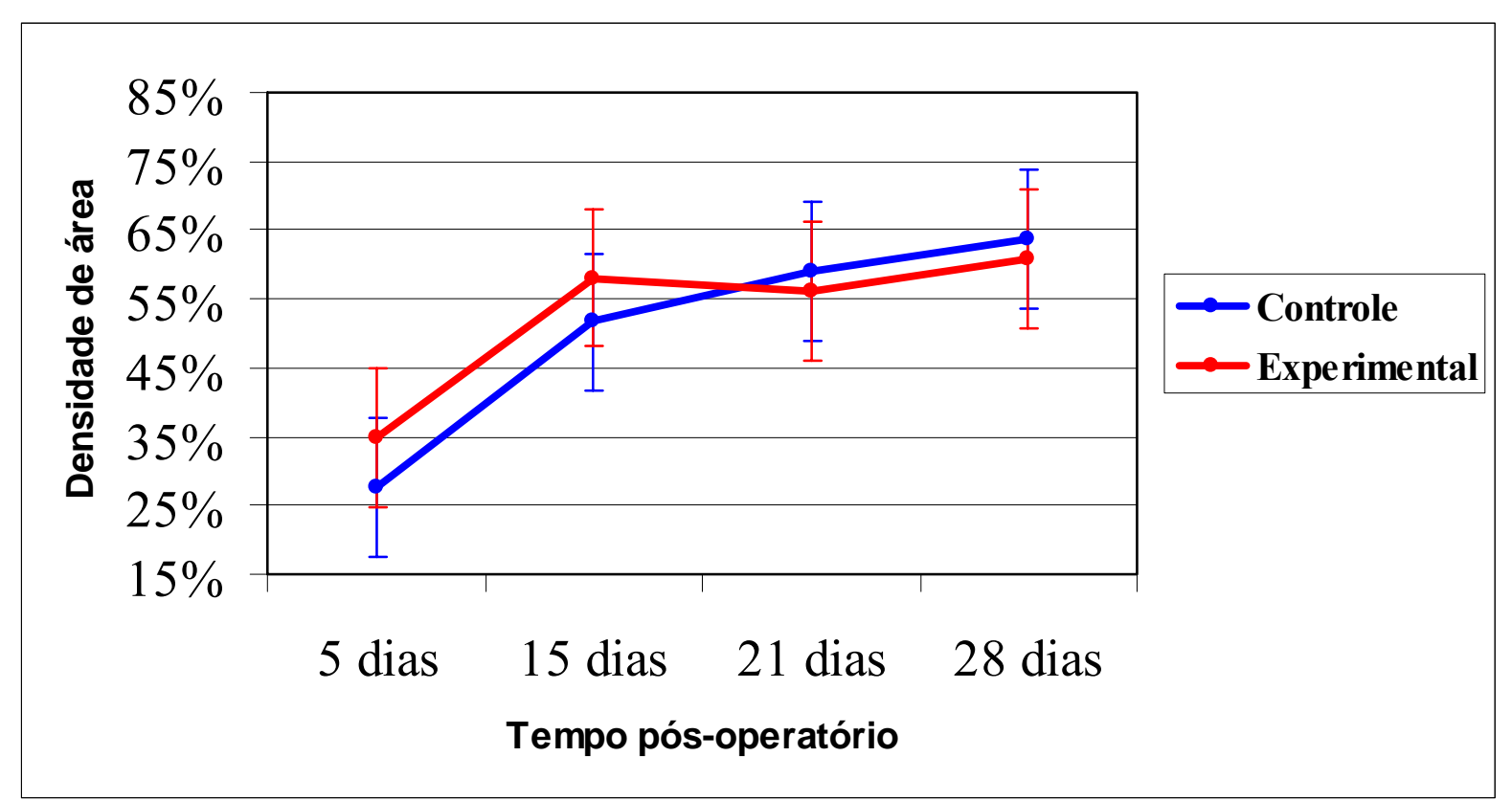

Figura 69 - Média das densidades de área ocupada por osso nos alvéolos dentais dos animais dos grupos controle e experimental de acordo com os tempos pós-operatório.

Os dados da figura demonstraram um aumento progressivo estatisticamente significativo $(\mathrm{p}=0,0000)$ da densidade de área ocupada por osso no decorrer dos dias de pósoperatório, tanto para o grupo controle quanto para o experimental. A maior evolução da quantidade de osso foi verificada entre o período de 5 até 15 dias de pós-operatório. No grupo controle os valores da densidade de área ocupada por osso do $15^{\circ}$ e $21^{\circ}$ e do $21^{\circ}$ e $28^{\circ}$ dias de pós-operatório foram iguais estatisticamente. Entre os períodos de 15 e 28 dias, os valores foram significativamente diferentes. No grupo experimental os valores da densidade de área ocupada por osso do $15^{\circ}, 21^{\circ}$ e $28^{\circ}$ dias de pós-operatório não apresentaram diferença significativa.

Em todos os períodos de tempo pós-operatório, a média das densidades de área ocupada por osso dos grupos controle e experimental não apresentaram diferença estatística significativa $(p=0,2106)$ entre os grupos. Entretanto, o comportamento dos grupos controle e experimental a respeito do aumento da quantidade de osso em função do tempo pósoperatório foi diferente estatisticamente $(\mathrm{p}=0,0282)$. 
Os resultados da morfometria da média das densidades de área ocupadas por osso nos alvéolos dentais dos grupos controle e experimental realizados pelo programa de imagens podem ser observados a seguir:

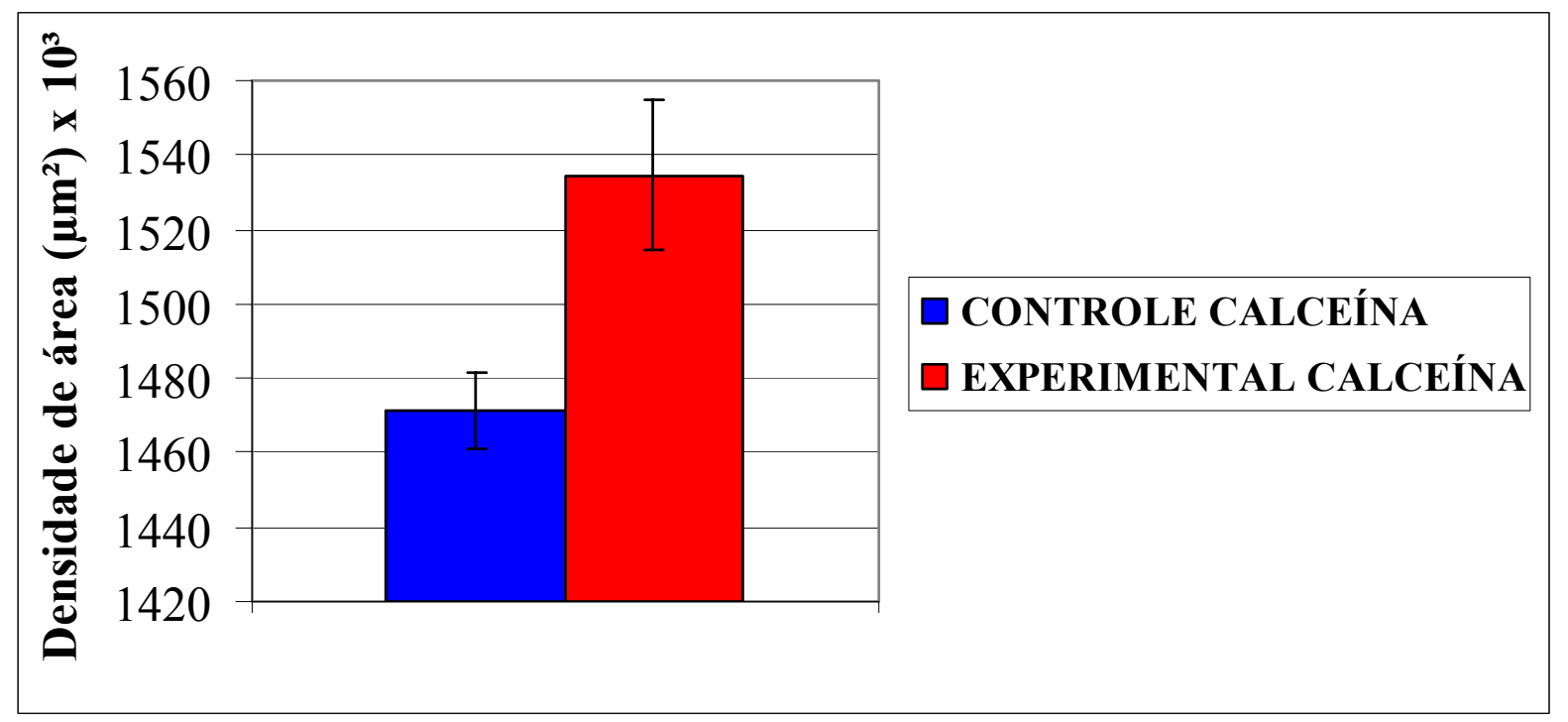

Figura 70 - Média das densidades de área ocupada por osso nos alvéolos dentais dos animais dos grupos controle e experimental que receberam calceína de acordo com os tempos pós-operatório.

Apesar da média das densidades de área ocupada por osso no grupo experimental ser maior do que no grupo controle, a diferença entre os valores encontrados nos dois grupos não foi significativa estatisticamente $(\mathrm{p}=0,6350)$. 


\section{DISCUSSÃO}

Regiões desdentadas no arco dental são constatações freqüentes observadas pelo cirurgião-dentista durante o exame clínico odontológico do indivíduo. A ausência de dentes é uma situação que ainda acomete muitas pessoas, independentemente da classe social. Vários trabalhos científicos (PIETROKOVSKI e MASSLER, 1967a; PIETROKOVSKI E MASSLER, 1967b; JOHNSON, 1969; GUGLIELMOTTI e CABRINI, 1985; JAHANGIRI et al., 1998; SCHROPP et al., 2003; ARAÚJO e LINDHE, 2005) demonstraram que após a extração dental ocorrem alterações dimensionais do processo alveolar. A utilização de próteses dentais nas áreas desdentadas é o tratamento para reabilitação funcional, estética e fonética que os dentes exerciam.

As próteses podem estar suportadas sobre dentes, mucosa e/ou implantes dentais osteointegráveis. Especificamente nos tratamentos que envolvem a reabilitação com próteses dentais implantossuportadas, o processo alveolar remanescente após a perda dental deve ser avaliado criteriosamente, pois o volume e a qualidade do osso são fundamentais para instalação de implantes dentais. Nos casos em que há quantidade insuficiente de osso alveolar, procedimentos cirúrgicos para enxertia de osso ou biomateriais podem ser realizados a fim de tentar recuperar o volume ósseo perdido.

Aichelmann-Reidy e Yukna (1998) e Hoexter (2002) relatam que o material de enxerto ideal para substituir o osso é aquele que apresenta as propriedades de osteogênese, osteoindução e osteocondução. A osteogênese é o mecanismo de formação óssea a partir da ação direta de osteoblastos. Materiais osteoindutores induzem a diferenciação de células mesenquimais osteoprogenitoras em osteoblastos para posteriormente produzir osso. A propriedade de osteocondução dos materiais permite que haja aposição do osso circunjacente do leito receptor sobre a superfície do material de enxerto. 
Segundo WANG et al. (2004) o uso de materiais de enxerto no interior do alvéolo dental após exodontia tem sido sugerido para minimizar a reabsorção fisiológica do processo alveolar e ajudar a reparação óssea do alvéolo dental. A seleção do material de enxerto deve ser baseada em critérios que abrange a quantidade disponível do material, a biocompatibilidade do enxerto para não causar reações imunológicas do hospedeiro, a facilidade de revascularização, a promoção de osteocondução e a substituição completa do material de enxerto por osso novo. Diversos autores (GROENEVELD, 1999; HOEXTER, 2002; MAZOCK et al., 2004; MINICHETTI et al., 2004; JENSEN et al., 2006) consideram o osso autógeno como o melhor material para enxertia de defeitos ósseos.

No presente trabalho foi estudada a influência do enxerto ósseo autógeno particulado no processo de reparo ósseo do alvéolo dental de ratos Wistar após exodontia. Kuboki et al. (1988), Becker et al. (1994), Gauthier et al. (1999) e Kanyama et al. (2003) afirmam que os sítios de extração dental representam um bom modelo experimental para avaliação da reparação de um defeito ósseo.

A seqüência dos acontecimentos histológicos envolvidos na reparação alveolar é basicamente similar para diferentes espécies de animais (BODNER et al., 1993), sendo que cada espécie apresenta períodos de tempo específicos para concluir todo o processo de reparo. Dalitz (1964) e Evian et al. (1982) estudaram a reparação alveolar após exodontia no homem. Relataram que há o preenchimento com tecido ósseo maduro de todo alvéolo dental por volta da 16 a semana (64 dias) de pós-operatório. Victor et al. (1977) e Okamoto e Fialho (1990) descreveram que o alvéolo dental após a exodontia do incisivo superior do rato é totalmente reparado e preenchido por osso por volta do $28^{\circ}$ e $30^{\circ}$ dias de pós-operatório. A partir dessas informações, pode-se sugerir que a reparação do alvéolo dental de ratos é concluída aproximadamente na metade do tempo gasto para o reparo alveolar em humanos. 
Utilizou-se como local doador do enxerto o osso ilíaco dos animais, pois a quantidade de osso disponível era suficiente para o preenchimento do alvéolo dental. O acesso cirúrgico e a remoção do enxerto não causaram dificuldades para locomoção dos animais no pósoperatório.

A aferição periódica da massa corpórea dos animais permitiu observar que a falta do dente incisivo superior direito, promovida pela exodontia, não impediu a alimentação dos animais, pois os mesmos aumentaram progressivamente a massa corpórea durante o período pós-operatório. O acesso cirúrgico para remoção do enxerto também não foi determinante para alterar o padrão de alimentação dos ratos, já que os resultados estatísticos não mostraram diferença significativa entre o ganho de massa corpórea dos animais controles e experimentais.

Em todos os animais utilizados para o experimento foi ministrada medicação pósoperatória. Utilizou-se a droga flunixin que é um antiinflamatório não-esteroidal e antipirético, com potente ação analgésica e que atua na inibição da ciclooxigenase (COX), enzima responsável pela síntese direta de prostaglandinas (mediadores do processo inflamatório). O outro medicamento utilizado foi um pentabiótico composto pela associação de benzilpenicilina benzatina, benzilpenicilina procaína, benzilpenicilina potássica, diidroestreptomicina base (sulfato) e estreptomicina base (sulfato).

A utilização da medicação pós-operatória teve o intuito de amenizar o desconforto pós-operatório dos animais, promovida pela ação analgésica do antiinflamatório, e de reduzir o risco de infecção por meio da aplicação do antibiótico. Apesar de ter sido ministrado o antibiótico e de os procedimentos cirúrgicos terem sido realizados respeitando-se as normas de biossegurança, vários animais apresentaram sinais de infecção do alvéolo dental e foram excluídos do experimento. 
A análise qualitativa dos cortes histológicos corados com hematoxilina e eosina de Harris do grupo controle apresentou características semelhantes aos resultados descritos nos trabalhos de Huebsch et al. (1952), Grandini et al. (1970), Okamoto e Russo (1973), Carvalho et al. (1983), Okamoto e Fialho (1990). Ressalva se faz ao período de 28 dias de pósoperatório, onde alguns animais apresentavam amplos espaços sem preenchimento ósseo, principalmente na porção central do alvéolo.

Nos trabalhos de Huebsch et al. (1952), Grandini et al. (1970), Okamoto e Russo (1973), Carvalho et al. (1983), Okamoto e Fialho (1990), em nenhum dos experimentos foi utilizada medicação pós-operatória. $\mathrm{O}$ aparente atraso no preenchimento total de osso no alvéolo em nosso experimento pode ser explicado pela aplicação de antiinflamatório no período pós-operatório.

Yogoshi et al. (2002) estudaram o efeito do diclofenaco na reparação do alvéolo dental após exodontia em ratos Wistar. Os animais receberam aplicações intraperitonial diárias de 10 $\mathrm{mg} / \mathrm{Kg}$ de diclofenaco, injetadas 1 dia antes da cirurgia e durante os 4 primeiros dias de pósoperatório. Constataram que o uso do medicamento causou significante atraso na neoformação óssea do alvéolo dental.

O diclofenaco é um antiinflamatório não-esteroidal que inibe a síntese de prostaglandinas. Como o flunixin também atua na inibição de prostaglandinas, pode-se inferir que os efeitos das drogas sobre a reparação do alvéolo dental depois da exodontia devam ser semelhantes.

O antibiótico não parece interferir na reparação alveolar. Haddad et al. (1965) estudaram o efeito da tetraciclina no reparo do alvéolo dental após exodontia em ratos Wistar. Foram aplicadas, por via subcutânea, doses diárias de $100 \mathrm{mg} / \mathrm{Kg}$ em um dos grupos de animais, desde o dia da cirurgia até o dia da eutanásia. A evolução do reparo alveolar nesses 
ratos não apresentou retardo na ossificação quando comparados aos alvéolos dentais dos ratos controles, que não receberam a medicação.

A análise dos cortes histológicos corados com hematoxilina e eosina de Harris dos grupos controle e experimental revelou que no $5^{\circ}$ dia de pós-operatório foram observados menos remanescente de coágulo sangüíneo no grupo experimental do que no grupo controle. Não foi identificada formação de trabéculas ósseas próximas às corticais alveolares no grupo experimental. Apesar de não ter sido realizada uma análise quantitativa para estimar o número de osteoclastos, no grupo experimental foram identificados mais osteoclastos do que no grupo controle. Todavia, constatou-se que ao redor dos fragmentos de enxerto há neoformação de osso. No interior do enxerto observaram-se lacunas vazias onde anteriormente se encontravam os osteócitos, que sofreram morte celular devido à falta de nutrição e pelo trauma ocasionado durante a cirurgia. A deposição de osso ao redor dos fragmentos de enxerto e a presença de lacunas vazias estão de acordo com o relato de Burchardt (1983).

As características histológicas analisadas nos períodos de 15, 21 e 28 dias de pósoperatório nos grupos controle e experimental foram semelhantes. Observou-se a organização e o espessamento progressivo das trabéculas ósseas. A diminuição de áreas preenchidas por remanescentes de coágulo sangüíneo, células inflamatórias e fibroblastos foi constatada durante a evolução do processo de reparo alveolar. É importante ressaltar a constatação de vasos sangüíneos penetrando os fragmentos de enxerto ósseo a partir do $15^{\circ}$ dia pósoperatório. Burchardt (1983) relata que a invasão vascular do enxerto permite a nutrição adequada para que células mesenquimais primitivas se diferenciem em células osteogênicas.

Ao final do período pós-operatório nem todos os fragmentos de enxerto foram reabsorvidos e depois substituídos por osso novo. Esses fragmentos encontrando-se integrados ao osso neoformado do alvéolo dental. Burchardt (1983) afirma que essa situação é característica do processo de reparação do enxerto ósseo cortical. No leito receptor, portanto, 
será observada uma mistura de osso vital, referente ao tecido ósseo neoformado, com osso não-vital, representado pelos fragmentos de enxerto ósseo.

A coloração dos cortes histológicos com picro-sírius permitiu observar em microscópio sob luz polarizada a disposição das fibras colágenas durante a reparação do alvéolo dental. A formação progressiva de fibras colágenas no decorrer do pós-operatório foi constatada nos grupos controle e experimental, e também nos relatos de Kurita et al. (1985) e Kuboki et al. (1988).

Kurita et al. (1985) relata que a proporção de fibras colágenas do tipo III em relação às fibras do tipo I é maior nos estágios iniciais da reparação do alvéolo dental, diminuindo gradualmente a partir do $7^{\circ}$ dia de pós-operatório. Em nosso trabalho não foi evidenciado o predomínio de fibras colágenas do tipo III sobre o tipo I no $5^{\circ}$ dia de pós-operatório. A realização de técnicas de imunohistoquímica, expressão de proteína ou expressão gênica do colágeno poderia nos fornecer maiores subsídios para identificar e quantificar os tipos de colágeno. Futuramente outras pesquisas serão realizadas a fim de enriquecer o conhecimento sobre o papel de cada tipo de colágeno na reparação alveolar.

Dentro dos limites de nossa metodologia, somente podemos afirmar que os alvéolos dos animais experimentais aparentemente apresentaram no período inicial de pós-operatório uma proporção maior de fibras coradas em verde, evidenciadas pelo picro-sírius, comparada aos alvéolos dentais dos ratos controles. Isso sugere que o osso alveolar do grupo experimental apresentava-se menos maduro que o osso alveolar dos ratos controles.

Vários trabalhos (HADDAD et al., 1965; BOYNE, 1966; ASTRAND e CARLSSON, 1969; HSIEH et al., 1995; GAUTHIER et al., 1999) também utilizaram marcadores de ossificação para estudar a reparação óssea do alvéolo dental após a exodontia. No presente experimento, a aplicação da calceína nos animais possibilitou observar histologicamente a deposição periódica de osso no alvéolo dental. Os animais dos grupos controle e experimental 
que receberam calceína apresentaram em seus alvéolos trabéculas ósseas bem organizadas e com disposição semelhante aos achados dos cortes histológicos dos alvéolos corados com hematoxilina e eosina de Harris. Observou-se que o tecido ósseo dos alvéolos dos ratos controle e experimental ocupava uma grande extensão do alvéolo com algumas áreas sem preenchimento.

Linhas de deposição mineral ao redor dos fragmentos de enxerto ósseo foram identificadas nos alvéolos dentais dos ratos experimentais. Essas linhas foram observadas tanto em microscopia sob luz convencional quanto sob luz fluorescente e evidenciam claramente a propriedade de osteocondução dos enxertos ósseos autógenos. As partículas de enxerto atuam como arcabouço para deposição de osso novo sobre suas superfícies.

Constatou-se também formação óssea extra-alveolar concomitante a reparação intraalveolar, caracterizada pela identificação de linhas de deposição mineral sobre o processo alveolar. O envolvimento do osso alveolar no reparo do alvéolo dental depois da exodontia foi relatado nos trabalhos de Boyne e Kruger (1962), Boyne (1966), Todo (1968) e Astrand e Carlsson (1969), indicando que o processo alveolar apresenta um importante papel na reparação alveolar. Astrand e Carlsson (1969) afirmam que a formação de osso fora do alvéolo pode ser um mecanismo compensatório, onde o processo alveolar tem sua estrutura reforçada após a perda dental.

Os dados referentes à análise quantitativa, realizada com sistema teste, revelaram o aumento constante da densidade de área ocupada por osso no alvéolo dental dos animais controles e experimentais, durante o transcorrer do período pós-operatório. A média das densidades de área preenchida por tecido ósseo não apresentou diferença estatística significativa entre os dois grupos.

Observou-se que a evolução da formação óssea nos alvéolos dos animais controle foi diferente quando comparada aos ratos experimentais. Essa diferença é constatada ao se 
analisar a porcentagem de área alveolar ocupada por osso durante o pós-operatório. Enquanto no grupo controle o aumento significativo de osso foi verificado nos períodos pós-operatório de 5 a 15 dias e de 15 a 28 dias, o grupo experimental teve sua formação máxima de osso no período de 5 a 15 dias.

Os trabalhos de Carvalho et al. (1997), Brandão et al. (2002) e Yugoshi et al. (2002) também realizaram análises morfométricas da quantidade de osso encontrada durante a reparação alveolar após exodontia.

Na primeira semana de pós-operatório Carvalho et al. (1997) encontraram cerca de $20 \%$ de osso no terço médio do alvéolo dental dos ratos controles, Brandão et al. (2002) relataram aproximadamente $25 \%$ e Yugoshi et al. (2002) constataram 17\% de osso. Nesse trabalho observa-se nos alvéolos dos ratos controles em torno de $27 \%$ de área preenchida por osso, no $5^{\mathrm{o}}$ dia de pós-operatório. Na segunda semana de pós-operatório Carvalho et al. (1997) relataram aproximadamente 50\% de área ocupada por osso, enquanto que Yugoshi et al. (2002) encontraram 36,2\%. A densidade de área de osso constatado no $15^{\circ}$ dia de pósoperatório no presente trabalho foi cerca de $52 \%$. Na terceira semana de pós-operatório observou-se nesse experimento aproximadamente $59 \%$ de osso formado, Carvalho et al. (1997) relataram cerca de 60\%, Yugoshi et al. (2002) encontraram 42,7\% e Brandão et al. (2002) constataram 52,2\%. Na quarta semana de pós-operatório encontramos em torno de $64 \%$ de preenchimento ósseo no alvéolo dental. Carvalho et al. (1997), nesse mesmo período de pós-cirúrgico, observaram aproximadamente $65 \%$ de volume de osso no alvéolo. A quantidade de osso formado nos períodos pós-operatórios avaliados neste trabalho se aproxima dos dados relatados nos trabalhos de Carvalho et al. (1997) e Brandão et al. (2002).

A média das densidades de área ocupada por osso dos grupos controle e experimental que receberam calceína não apresentou diferença estatisticamente significativa entre os 
grupos. Observou-se um padrão de deposição óssea no alvéolo dental semelhante para os grupos controle e experimental.

Outros trabalhos (Boyne e Kruger, 1962; Becker et al., 1994; Becker et al., 1996; Becker et al., 1998) também utilizaram o osso autógeno para enxertia do alvéolo dental após a exodontia.

Boyne e Kruger (1962) estudaram a reparação do alvéolo dental após exodontia em cães. Decorrida a extração dental, os autores preencheram o alvéolo dos animais com osso heterógeno bovino ou osso homógeno congelado ou osso autógeno. No pós-operatório, os cães receberam aplicações periódicas de tetraciclina, como marcador de ossificação. Como o objetivo do trabalho foi desenvolver uma técnica para observação do marcador de ossificação sob microscópio de luz fluorescente, as características histológicas da reparação óssea intraalveolar não foram descritas no trabalho.

Becker et al. (1994) enxertaram osso desmineralizado congelado seco (DFDBA) e osso autógeno em alvéolos dentais de humanos após exodontia. Depois de 3 a 13 meses da enxertia, biópsias dos locais enxertados foram coletadas previamente à instalação de implantes. Constataram que vários fragmentos de DFDBA não apresentaram formação de osso ao redor de suas superfícies, parecendo haver atraso na reparação alveolar. Osso lamelar ou imaturo foi observado integrado aos fragmentos de enxerto autógeno, sem promover alteração do reparo do alvéolo dental.

Becker et al. (1996) realizaram um estudo em humanos a fim de verificar a influência do preenchimento com osso autógeno, DFDBA e osso mineralizado congelado seco (MFDBA) na reparação de alvéolos dentais depois da exodontia. Dentro das limitações do estudo, concluíram que os materiais de enxerto utilizados não pareceram proporcionar uma maior formação óssea considerável dos alvéolos dentais. 
Becker et al. (1998) observaram a influência do osso bovino inorgânico, DFDBA, osso autógeno e uma combinação de proteína morfogenética do osso (BMP) com proteínas nãocolágenas do osso (NCP) na reparação do alvéolo dental após exodontia em humanos. Em alguns pacientes foram instalados micro-implantes adjacente aos sítios enxertados. A análise dos resultados não demonstrou melhorias na reparação alveolar ao se utilizar esses materiais de enxerto. Somente a associação de BMP/NCP pareceu promover neoformação óssea significativa. Os autores não recomendam o uso de osso bovino inorgânico, DFDBA e osso autógeno para melhorar a reparação do alvéolo dental ou para promover a formação de osso para instalação de implantes osteointegráveis.

Nos trabalhos de Boyne e Kruger, 1962; Becker et al., 1994; Becker et al., 1996; Becker et al., 1998 acima referidos, somente uma análise histológica qualitativa foi realizada para descrever a reparação do alvéolo dental enxertado com osso autógeno após exodontia. A ausência de dados morfométricos a respeito da quantidade de osso presente no alvéolo dental limita a determinação sobre a influência do enxerto ósseo autógeno na neoformação de osso durante o reparo alveolar depois da extração dental.

O relato desse trabalho refere-se à reparação alveolar após a extração dental em ratos Wistar. Sabe-se que a seqüência dos eventos ocorridos durante o reparo do alvéolo é semelhante entre diversas espécies, incluindo o rato e o homem. Baseado nisso, espera-se que resultados semelhantes sejam observados em humanos. Dessa forma, pode ser feita uma aplicação clínica do trabalho, onde a enxertia alveolar com osso autógeno particulado não traria benefícios para a neoformação óssea no alvéolo dental.

Vale ressaltar que neste trabalho somente foi avaliada a influência do enxerto ósseo autógeno particulado na neoformação óssea do alvéolo dental após a exodontia, sem levar em consideração as possíveis interferências do enxerto sobre o processo de reabsorção fisiológica 
do alvéolo posteriormente à extração dental. Novas pesquisas deveriam ser realizadas com o intuito de esclarecer o papel do enxerto ósseo autógeno na reabsorção do rebordo alveolar. 


\section{CONCLUSÃO}

De acordo com esse estudo realizado para verificar a influência do enxerto ósseo autógeno particulado na reparação do alvéolo dental de ratos Wistar após exodontia, concluiuse que o enxerto ósseo autógeno não promoveu um aumento estatisticamente significativo da neoformação óssea no alvéolo dental após exodontia. Portanto, o preenchimento alveolar com osso autógeno particulado não demonstrou melhorar ou acelerar a reparação óssea do alvéolo dental posteriormente à extração dental. Em vista dos resultados, acreditamos que o uso clínico do enxerto ósseo autógeno no alvéolo dental, com finalidade de promover maior formação óssea, não está indicado. 


\section{REFERÊNCIAS BIBLIOGRÁFICAS*}

1. AICHELMANN-REIDY, M. E.; YUKNA, R. A. Bone replacemet grafts: the bone substitutes. Dent Clin North Am, v. 42, n. 3, p. 491-503, July. 1998.

2. ALBERIUS, P.; GORDH, M.; LINDBERG, L.; JOHNELL, O. Effect of cortical perforations of both graft and host bed on onlay incorporation to the rat skull. Eur J Oral Sci, v. 104, n. 5-6, p. 554-61, Oct./Dec. 1996.

3. ALLING, C. C.; KERR, D. A. Trauma as a factor causing delayed repair of dental extraction sites. J Oral Surg, v. 15, n. 1, p. 3-11, Jan. 1957.

4. ALVES, M. C. R.; OKAMOTO, T. Influência do "stress" no processo de reparo em feridas de extração dental: estudo histológico em ratos. Rev Odont UNESP, v. 18, n. 1/2, p. 119-30, 1989.

5. AMLER, M. H.; JOHNSON, P. L.; SALMAN, I. Histological and histochemical investigation of human alveolar socket healing in undisturbed extraction wounds. J Am Dent Assoc, v. 61, p. 32-44, July 1960.

6. AMLER, M. H. The time sequence of tissue regeneration in human extraction wounds. Oral Surg Oral Med Oral Pathol, v. 27, n. 3, p. 309-18, Mar. 1969.

7. ARAÚJO, M. G.; LINDHE, J. Dimensional ridge alterations following tooth extraction. An experimental study in the dog. J Clin Periodontol, v. 32, p. 212-18, 2005.

8. ASTRAND, P.; CARLSSON, G. E. Changes in the alveolar process after extractions in the white rat a histologic and fluorescence microscopic study. Acta Odont Scand, v. 27, n. 1, p.113-27, 1969.

9. BAPTISTA, L. C. P. Ação da hidroxiapatita reabsorvível na reparação do alvéolo, após extração dental, em ratos diabéticos. 2004. 82f. Dissertação (Mestrado) Instituto de Ciências Biomédicas da Universidade de São Paulo, São Paulo, 2004.

\footnotetext{
* De acordo com: ASSOCIAÇÃO BRASILEIRA DE NORMAS TÉCNICAS (ABNT). Informação e elaboração - referências - elaboração. NBR 6023, Rio de Janeiro, 2000.
} 
10. BAUTZ, W. G. Repercussões morfológicas da desnutrição protéica pré e pós-natal e da renutrição pós-natal no reparo da mucosa e do osso alveolar da mandíbula de ratos após a extração do primeiro molar. 2006. 81f. Dissertação (Mestrado) - Instituto de Ciências Biomédicas da Universidade de São Paulo, São Paulo, 2006.

11. BECKER, W.; BECKER, B. E.; CAFFESSE, R. A comparison of demineralized freezedried bone and autologous bone to induce bone formation in human extraction sockets. J Periodontol, v. 65, n. 12, p. 1128-33, Dec. 1994.

12. BECKER, W.; URIST, M.; BECKER, B. E.; JACKSON, W.; PARRY, D. A.; BARTOLD, M.; VINCENZZI, G.; GEORGES, D. D.; NIEDERWANGER, M. Clinical and histologic observations of sites implanted with intraoral autologous bone grafts or allografts: 15 human case reports. J Periodontol, v. 67, n. 10, p. 1025-33, Oct. 1996.

13. BECKER, W.; CLOKIE, C.; SENNERBY, L.; URIST, M. R.; BECKER, B. E. Histologic findings after implantation and evaluation of different grafting materials and titanium micro screws into extraction sockets: case reports. J Periodontol, v. 69, n. 4, p. 414-21, Apr. 1998.

14. BECKER, W. Treatment of small defects adjacent to oral implants with various biomaterials. Periodontol 2000, v. 33, p. 26-35, 2003.

15. BEZERRA, F. J. B.; MENDONÇA, R. G. Enxertos ósseos autógenos: sítios doadores e técnicas intrabucais. In: BEZERRA, F. J. B; LENHARO, A. Terapia avançada em implantodontia. São Paulo: Artes Médicas, 2002. cap. 3, p. 31-75.

16. BODNER, L.; DAYAN, D.; ROTHCHILD, D.; HAMMEL, I. Extraction wound healing in desalivated rats. J Oral Pathol Med, v. 20, p. 176-78, 1991.

17. BODNER, L.; KAFFE, I.; LITTNER, M. M.; COHEN, J. Extraction site healing in rats: a radiologic densitometric study. Oral Surg Oral Med Oral Pathol, v. 75, n.3, p. 367-72, Mar. 1993.

18. BOYNE, P. J.; KRUGER, G. O. Fluorescence microscopy of alveolar bone repair. Oral Surg Oral Med Oral Pathol, v.15, n. 3, p.265-81, Mar. 1962. 
19. BOYNE, P. J. Osseous repair of the postextraction alveolus in man. Oral Surg Oral Med Oral Pathol, v. 21, n. 6, p. 805-13, June 1966.

20. BRASIL. Ministério da Saúde, Coordenação Nacional de Saúde Bucal. Banco de dados da pesquisa. Condições de Saúde Bucal da População Brasileira - Projeto SBBrasil 2003. Disponível em: <http://www.saude.gov.br>. Acesso em: 3 jul. 2006.

21. BRANDÃO, A. C.; BRENTEGANI, L. G.; NOVAES JÚNIOR, A. B.; GRISI, M. F. M.; SOUZA, S. L. S.; TABA JÚNIOR, M.; SALATA, L. A. Histomorphometric analysis of rat alveolar wound healing with hydroxyapatite alone or associated to BMP's. Braz Dent J, v. 13, n. 3, p. 147-154, 2002.

22. BURCHARDT, H. The biology of bone graft repair. Clin Orthop Rel Res, v. 174, p. 28-42, Apr. 1983.

23. CALIXTO, R. F. E. Implante de um floculado de resina derivada do óleo de mamona (Ricinus communis) em alvéolo de rato imediatamente após extração dental. Avaliações histológica e histométrica da biocompatibilidade e da cronologia do reparo ósseo. 2001. 90f. Tese (Mestrado) - Faculdade de Odontologia de Ribeirão Preto, Universidade de São Paulo, Ribeirão Preto, 2001.

24. CARANO, R. A. D.; FILVAROFF, E. H. Angiogenesis and bone repair. Drug Discovery Today, v. 8, n. 21, p.980-89, Nov. 2003.

25. CARDAROPOLI, G.; ARAÚJO, M.; LINDHE, J. Dynamics of bone tissue formation in tooth extraction sites: an experimental study in dogs. J Clin Periodontol, v. 30, p. 809-18, 2003.

26. CARDAROPOLI, G.; ARAÚJO, M.; HAYACIBARA, R.; SUKEKAVA, F.; LINDHE, J. Healing of extraction sockets and surgically produced - augmented and nonaugmented - defects in the alveolar ridge: an experimental study in the dog. J Clin Periodontol, v. 32, p. 435-40, 2005. 
27. CARVAlho, A.; CAStro, A. L.; PINTO, R. S.; PINTO, M. C. S. Mineralização no processo de reparo em feridas de extração dentária em ratos contribuição ao estudo densitométrico. Ars Cvrandi em Odontologia. Out. 1980.

28. CARVALHO, A. C. P.; PINTO, M. C. S., SOUSA, V. Implante de "osso sintético" em alvéolos dentais: estudo clínico e radiográfico em pacientes. Rev APCD, v. 26, n. 3, p. 125-28, maio / jun. 1972.

29. CARVAlho, A. C. P.; OKAMOTO T. Cuidados pós-exodônticos: considerações clínicas e experimentais. Ars Cvrandi em Odontologia, v. 5, p. 19-27, abr. 1978.

30. CARVALHO, A. C. P.; OKAMOTO, T. Reparação do alvéolo dental. In: CARVALHO, A. C. P.; OKAMOTO, T. Cirurgia bucal: fundamentos experimentais aplicadas à clínica. São Paulo: Panamericana, 1987. cap. 5, p. 55-80.

31. CARVAlho, P. S. P.; OKAMOTO, T.; CARVAlHO, A. C. P. Processo de reparo em feridas de extração dental: influência da irrigação e da curetagem e irrigação intraalveolar. Estudo histológico em ratos. RGO, v.31, n. 1, p. 19-22, jan./mar., 1983.

32. CARVALHO, P. S. P.; VASCONCELOS, L. W.; PI, J. Influence of bed preparation on the incorporation of autogenous bone grafts: a study in dogs. Int J Oral Maxillofac Implants, v. 15, n. 4, p. 565-70, 2000.

33. CARVAlho, T. L. L.; BOMBONATO, K. F.; BRENTEGANI, L. G. Histometric analysis of rat alveolar wound healing. Braz Dent J, v. 8, n. 1, p. 9-12, 1997.

34. CLAFLIN, R. S. Healing of disturbed and undisturbed extraction wounds. J Am Dent Assoc, v. 23, n. 6, p. 945-59, June 1936.

35. DALITZ, G. D. A radiographic study of the rate at which human extraction wounds heal. Austr Dent J, v. 9, n. 5, p. 466-73, Dec. 1964.

36. DEVLIN, H.; FERGUSON, M. W. J. Alveolar ridge resorption and mandibular atrophy: a review of the role of local and systemic factors. Br Dent J, v. 170, n. 3, p.101-04, Feb. 1991. 
37. DEVLIN, H.; HOYLAND, J.; FREEMONT, A. J.; SLOAN, P. Localization of procollagen type II mRNA and collagen type II in the healing tooth socket of the rat. Arch Oral Biol, v. 40, n. 3, p. 181-85, 1995.

38. DEVLIN, H.; GARLAND, H.; SLOAN, P. Healing of tooth extraction sockets in experimental diabetes mellitus. J Oral Maxillofac Surg, v. 54, n. 9, p. 1087-91, Sept. 1996.

39. DEVLIN, H.; HOYLAND, J.; NEWALL, J. F.; AYAD, S. Trabecular bone formation in the healing of the rodent molar tooth extraction socket. J Bone Miner Res, v. 12, n. 12 , p. 2061-67, Dec. 1997.

40. DEVLIN, H.; SLOAN, P. Early bone healing events in the human extraction socket. Int J Oral Maxillofc Surg, v. 31, p. 641-645, 2002.

41. DONOVAN, M. G.; DICKERSON, N. C.; HANSON, L. J.; GUSTAFSON, R. B. Maxillary and mandibular reconstruction using calvarial bone grafts and branemark implants: a preliminary report. J Oral Maxillofac Surg, v. 52, n. 6, p. 588-94, June 1994.

42. EULER, H. Die Heilung von Extraktionswunden. Deutsche Monat Zahnheilk, v. 41, p. 685-700, Dez. 1923.

43. EVIAN, C. I.; ROSENBERG, E. S.; COSLET, J. G.; CORN, H. The osteogenic activity of bone removed from healing extraction sockets in humans. J Periodontol, v. 53, n. 2, p. 81-85, Feb. 1982.

44. FERREIRA, L. C. Histomorfometria da neoformação óssea em ratas Wistar ooforectomizadas submetidas à instalação de implantes de titânio com e sem fosfato tricálcico. 2003. Dissertação (Mestrado) - Instituto de Ciências Biomédicas da Universidade de São Paulo, São Paulo, 2003.

45. FONSECA, R. J.; CLARK, P. J.; BURKES JUNIOR, E. J.; BAKER, R. D.; HILL, C. Revascularization and healing of onlay particulate autologous bone grafts in primates. J Oral Surg, v. 38, n. 8, p. 572-77, Aug. 1980. 
46. FROUM, S.; CHO, S. C.; ROSENBERG, E.; ROHRER, M.; TARNOW, D. Histological comparison of healing extraction sockets implanted with bioactive glass or demineralized freeze-dried bone allograft: a pilot study. J Periodontol, v. 73, n. 1, p. 94-102, Jan. 2002.

47. GAUTHIER, O.; BOIX, D.; GRIMANDI, G.; AGUADO, E.; BOULER, J.; WEISS, P.; DACULSI, G. A new injectable calcium phosphate biomaterial for immediate bone filling of extraction sockets: a preliminary study in dogs. J Periodontol, v. 70, n. 4, p. 375-83, Apr. 1999.

48. GRANDINI, S. A.; MIGLIORINI, R. H.; OKAMOTO, T. Processo de reparo em feridas de extração dental em ratos com diabete aloxânico (estudo histológico). Bol Fac Farm Odont Ribeirão Preto, v. 7, n. 1, p. 47-63, 1970.

49. GRANDINI, S. A. The effect if partial-pancreatectomy-induced diabetes on wound healing subsequent to tooth extraction: histologic study in rats. Oral Surg, v. 45, n. 2, p. 190-99, Feb. 1978.

50. GRANDINI, S. A.; BRENTEGANI, L. G.; NOVAES, A. B.; MIGLIORINI, R. H. Protein synthesis in wound after tooth extraction in pancreatectomized diabetic rats. Braz Dent J, v. 1, n. 1, p. 25-30, 1990.

51. GROENEVELD, E. H. J.; VAN DEN BERGH, J. P. A.; HOLZMANN, P.; TEN BRUGGENKATE, C. M.; TUINZING, D. B.; BURGER, E. H. Histomorphometrical analysis of bone formed in human maxillary sinus floor elevations grafted with OP-1 device, demineralized bone matriz or autogenous bone. Clin Oral Impl Res, v. 10, n. 6, p. 499-509, Dec. 1999.

52. GUGLIELMOTTI, M. B.; CABRINI, R. L. Alveolar wound healing and ridge remodeling after tooth extraction in the rat: a histologic, radiographic and histometric study. J Oral Maxillofac Surg, v. 43, p. 359-364, 1985.

53. HADDAD, A.; HETEM, S.; BRANDÃO, H. J. S.; PINTO, R. S. A tetraciclina no processo de reparo de feridas de extração dental de ratos. Rev Fac Odont Araçatuba, v. 1, n. 2, p. 33-42, jul./dez. 1965. 
54. HOEXTER, D. L. Bone regeneration graft materials. J Oral Implantol, v. 28, n. 6, p. $290-94,2002$.

55. HSIEH, Y. D.; DEVLIN, H.; ROBERTS, C. Early alveolar ridge osteogenesis following tooth extraction in the rat. Arch Oral Biol, v. 39, n. 5, p. 425-28, 1994.

56. HSIEH, Y. D.; DEVLIN, H.; McCORD, F. The effect of ovariectomy on the healing tooth socket of the rat. Arch Oral Biol, v. 40, n. 6, p. 529-31, 1995.

57. HUEBSCH, R. F.; COLEMAN, R. D.; FRANDSEN, A. M.; BECKS, H. The healing process following molar extraction: normal male rats (long-evans strain). Oral Surg Oral Med Oral Pathol, v. 5, p. 864-76, Aug. 1952.

58. HUEBSCH, R. F.; HANSEN, L. S. A histopathologic study of extraction wounds in dogs. Oral Surg Oral Med Oral Pathol, v. 28, n. 2, p. 187-96, Aug. 1969.

59. HUPP, J. R. Avaliação do estado de saúde pré-operatório. In: PETERSON, L. J. et al. Cirurgia oral e maxillofacial contemporânea. 3. ed. Rio de Janeiro: Guanabara Koogan, 2000. cap. 1, p. 2-21.

60. ISAKA, J.; OHAZAMA, A.; KOBAYASHI, M.; NAGASHIMA, C.; TAKIGUCHI, T.; KAWASAKI, H.; TACHIKAWA, T.; HASEGAWA, K. Participation of periodontal ligament cells with regeneration of alveolar bone. J Periodontol, v. 72, n. 3, p. 314-23, Mar. 2001.

61. JAHANGIRI, L.; DEVLIN, H.; TING, K.; NISHIMURA, I. Current perspectives in residual ridge remodeling and its clinical implications: a review. J Prosthet Dent, v. 80, n. 2, p. 224-37, Aug. 1998.

62. JENSEN, J.; SINDET-PEDERSEN, S. Autogenous mandibular bone grafts and osseointegrated implants for reconstruction of the severely atrophied maxilla: a preliminary report. J Oral Maxillofac Surg, v. 49, n. 12, p. 1277-87, Dec. 1991.

63. JENSEN, S. S.; BROGGINI, N.; HJØRTING-HANSEN, E.; SCHENK, R.; BUSER, D. Bone healing and graft resorption of autograft, anorganic bovine bone and $\beta$-tricalcium 
phosphate. A histologic and histomorphometric study in the mandibles of minipigs. Clin Oral Impl Res, v. 17, p. 237-43, 2006.

64. JOHANSEN, J. R.; GILHUUS-MOE, O. Repair of the post-extraction alveolus in the guinea pig: a histological and autoradiographic study. Act Odont Scand, v. 27, n. 1, p. 249-58, 1969.

65. JOHANSEN, J. R. Repair of the post-extraction alveolus in the Wistar rat: a histological and autoradiographic study. Act Odont Scand, v. 21, n. 4, p. 441-61, 1970.

66. JOHNSON, K. A study of the dimensional changes occurring in the maxilla following tooth extraction. Austr Dent J, v. 14, n. 4, p. 241-44, Aug. 1969.

67. JUNQUEIRA, L. C.; CARNEIRO, J. Histologia básica. 10. ed. Rio de Janeiro: Guanabara Koogan, 2004.

68. KANYAMA, M.; KUBOKI, T.; AKIYAMA, K.; NAWACHI, K. MIYAUCHI, F. M.; YATANI, H.; KUBOTA, S.; NAKANISHI, T.; TAKIGAWA, M. Connective tissue growth factor expressed in rat alveolar bone regeneration sites after tooth extraction. Arch Oral Biol, v. 48, p. 723-30, 2003.

69. KÖNIG JÚNIOR, B.; BECK, T. J.; KAPPERT, H. F.; KAPPERT, C. C.; MASUKO, T. S. A study of different calcification areas in newly formed bone 8 weeks after insertion of dental implants in rabbit tibias. Ann Anat, v. 180, p. 471-75, 1998.

70. KUBOKI, Y.; HASHIMOTO, F.; ISHIBASHI, K. Time-dependent changes of collagen crosslinks in the socket after tooth extraction in rabbits. J Dent Res, v. 67, n. 6, p. 944-48, June 1988.

71. KURITA, K.; HASHIMOTO, Y.; TAKEI, T.; KAWAI, T.; HAYAKAWA, T. Changes in collagen types during the healing of rabbit tooth extraction wounds. J Dent Res, v. 64, n. 1, p. 28-32, Jan. 1985.

72. LALANI, Z.; WONG, M.; BREY, E. M.; MIKOS, A. G.; DUKE, P. J. Spatial and temporal localization of transforming growth factor- $\beta 1$, bone morphogenetic protein-2, 
and platelet-derived growth factor-A in healing tooth extraction sockets in a rabbit model. J Oral Maxillofac Surg, v. 61, p. 1061-72, 2003.

73. LALANI, Z.; WONG, M.; BREY, E. M.; MIKOS, A. G.; DUKE, P. J.; JOHNSTON, C. Spatial and temporal localization of secretory $\operatorname{IgA}$ in healing tooth extraction sockets in a rabbit model. J Oral Maxillofac Surg, v. 62, p. 466-72, 2004.

74. LEKOVIC, V.; KENNEY, E. B.; WEINLAENDER, M.; HAN, T.; KLOKKEVOLD, P.; NEDIC, M.; ORSINI, M. A bone regenerative approach to alveolar ridge maintenance following tooth extraction: report f 10 cases. J Periodontol, v. 68, n. 6, p. 563-70, June 1997.

75. LEKOVIC, V.; CAMARGO, P. M.; KLOKKEVOLD, P. R.; WEINLAENDER, M.; KENNEY, E. B.; DIMITRIJEVIC, B.; NEDIC, M. Preservation of alveolar bone in extraction sockets using bioabsorbable membranes. J Periodontol, v. 69, n. 9, p. 1044-49, Sep. 1998.

76. LEVIN, L.; NITZAN, D.; SCHWARTZ-ARAD, D. Success of dental implants placed in intraoral block bone grafts. J Periodontol, v. 78, n. 1, p. 18-21, Jan. 2007.

77. LIN, W. L.; McCULLOCH, C. A. G.; CHO, M. I. Differentiation of periodontal ligament fibroblasts into osteoblasts during socket healing after tooth extraction in the rat. Anat Rec, v. 240, n. 4, p. 492-506, Dec. 1994.

78. LOPES, C. C. Análise do remodelamento ósseo após a inserção de implantes dentais de diferentes superfícies em tíbias de coelhos. 2003. Tese (Doutorado) - Instituto de Ciências Biomédicas da Universidade de São Paulo, São Paulo, 2003.

79. LUGero, G. G.; CAPARBO, V. F.; GUZZO, M. L. KÖNIG JÚNIOR, B.; JORGETTI, V. Histomorphometric evaluation of titanium implants in osteoporotic rabbits. Implant Dent, v. 9, p. 303-09, 2000.

80. LUNDGREN, S.; RASMUSSON, L.; SJÖSTRÖM, M.; SENNERBY, L. Simultaneous or delayed placement of titanium implants in free autogenous iliac bone grafts: 
histological analysis of thr bone graft-titanium interface in 10 consecutive patients. Int $\mathbf{J}$ Oral Maxillofac Surg, v. 28, n. 1, p. 31-37, Feb. 1999.

81. MADID, P. Influência do osso inorgânico na reparação da ferida após extração dental em ratos Wistar diabéticos. 2004. Dissertação (Mestrado) - Instituto de Ciências Biomédicas da Universidade de São Paulo, São Paulo, 2004.

82. MAgAlhãeS, A. E. O.; OKAMOTO, T.; BARROSO, J. S. Influência da fratura da crista óssea alveolar no processo de reparo, em feridas de extração dental. Estudo histológico em ratos. Rev Ass Paul Cirurg Dent, v. 36, n. 2, mar./abr., 1982.

83. MALETTA, J. A.; GASSER, J. A.; FONSECA, R. J.; NELSON, J. A. Comparison of the healing and revascularization of onlayed autologous and lyophilized allogeneic rib grafts to the edentulous maxilla. J Oral Maxillofac Surg, v. 41, n. 8, p. 487-99, Aug. 1983.

84. MAZOCK, J.B.; SCHOW, S. R., TRIPLETT, R. G. Proximal tibia bone harvest: review of technique, complications, and use in maxillofacial surgery. Int J Oral Maxillofac Implants, v. 19, n. 4, p. 586-93, 2004.

85. McMiLlAN, M. D. Oral changes following tooth extraction in normal and alloxan diabetic rats, Part I, macroscopic observations. N Z Dent J, v. 66, n. 305, p. 239-47, July 1970.

86. McMILLAN, M. D. Oral changes following tooth extraction in normal and alloxan diabetic rats, Part II, microscopic observations. N Z Dent J, v. 67, n. 307, p. 23-31, Jan. 1971.

87. MINICHETTI, J. C.; D’AMORE, J. C.; HONG, A. Y. J.; CLEVELAND, D. B. Human histologicanalysis of mineralized bone allograft (puros) placement before implant surgery. J Oral Implantol, v. 30, n. 2, p. 74-82, 2004.

88. MUNHOZ, E. A. Avaliação radiográfica de enxerto ósseo xenogênico em alvéolos de terceiros molares inferiores não-irrompidos. 2005. 121f. Dissertação (Mestrado) Faculdade de Odontologia de Bauru, Universidade de São Paulo, São Paulo, 2005. 
89. NEMCOVSKY, C. E.; SERFATY, V. Alveolar ridge preservation following extraction of maxillary anterior teeth: report on 23 consecutive cases. J Periodontol, v. 67, n. 4, p. 390-95, Apr. 1996.

90. NKENKE, E.; WEISBACH, V.; WINCKLER, E.; KESSLER; P.; SCHULTZEMOSGAU, S.; WILTFANG, J.; NEUKAM, F. W. Morbidity of harvesting of bone grafts from the iliac crest for preprosthetic augmentation procedures: a prospective study. Int $\mathbf{J}$ Oral Maxillofac Surg, v. 33, p. 157-63, 2004.

91. OCAÑA, R. P. Avaliação da neoformação óssea em enxertos de hidroxiapatita em alvéolos de coelhos. 2001. 52f. Dissertação (Mestrado) - Instituto de Ciências Biomédicas, Universidade de São Paulo, São Paulo, 2001.

92. OKAMOTO, T.; RUSSO, M. C. Wound healing following tooth extraction. Histochemical study in rats. Rev Fac Odont Araçatuba, v. 2, n. 2, 1973.

93. OKAMOTO, T.; FIALHO, A. C. V. Estudo histológico comparativo entre dois métodos de obtenção de cortes de alvéolos de ratos. Rev Odont UNESP, v. 19, n. 1, p. 63-74, 1990.

94. OKAMOTO, T.; OKAMOTO, R.; ALVES REZENDE, M. C. R.; GABRIELLI, M. F. R. Interference of the blood clot on granulation tissue formation after tooth extraction. Histomorphological study in rats. Braz Dent J, v. 5, n. 2, p. 85-92, 1994.

95. OTTONI, C. E. C.; CHOPARD, R. P. Histomorphometric evaluation of new bone formation in diabetic rats submitted to insertion of temporary implants. Braz Dent $\mathbf{J}$, v. 15, n. 2, p. 87-92, 2004.

96. PALECKIS, L. G. P. Reparação inicial de enxertos ósseos autógenos em bloco ou em partículas: estudo microscópico em cães. 2004. 121f. Tese (Doutorado) - Universidade Estadual Paulista, Faculdade de Odontologia, Araçatuba, 2004.

97. PIETROKOVSKI, J.; MASSLER, M. Alveolar ridge resorption following tooth extraction. J Prosthet Dent, v. 17, n. 1, p.21-27, Jan. 1967a. 
98. PIETROKOVSKI, J.; MASSLER, M. Ridge remodeling after tooth extraction in rats. J Dent Res, v. 46, n. 1, p.222-31, Jan.-Feb. 1967 b.

99. PINTO, L. P.; FERREIRA, A. G. M., OliVEIRA, H. T. R.; CAUDURO, F. S. Reconstrução de maxila atrófica com enxerto de tíbia para posterior reabilitação com implantes osseointegrados: relato de caso clínico. Rev Bras Implantodont Prótese Implant, v. 11, n. 41, p.42-48, jan./mar. 2004.

100.SALOMÃO, J. I. S.; GRANDINI, S. A.; OKAMOTO, T. Processo de reparo em feridas de extração dental em ratas ooforectomizadas: estudo histológico. Rev Fac Odont Araçatuba, v. 3, n. 2, p. 183-95, 1974.

101.SANTOS JÚNIOR, P. V.; MELHADO, R. M. Efeitos da estimulação ultra-sônica sobre o processo de reparo em ferida de extração dental: estudo histológico em ratos. Rev Odont UNESP, v. 19, n. 1, p. 291-99, 1990.

102.SCHROPP, L.; WENZEL, A.; KOSTOPOULOS, L. KARRING, T. Bone healing and soft tissue contour changes following single-tooth extraction: a clinical and radiographic 12-month prospective study. Int J Periodontontics Restorative Dent, v. 23, n. 4, p. 313-23, Aug. 2003.

103. SHAFER, W. G. The effect of cortisone on the healing of extraction wounds in the rat. J Dent Res, v. 33, n. 1, p. 4-11, Feb. 1954.

104.SHYNG, Y. C.; DEVLIN, H.; RICCARDI, D.; SLOAN, P. Expression of cartilagederived retinoic acid-sensitive protein during healing of the rat tooth-extraction socket. Arch Oral Biol, v. 44, n. 9, p. 751-57, 1999.

105. SIMPSON, H. E. Trauma as a factor causing delayed repair of dental extraction sites. J Oral Surg, v. 15, n. 1, p. 3-11, Jan. 1957.

106. SIMPSON, H. E. Experimental investigation into the healing of extraction wounds in macacus rhesus monkeys. J Oral Surg, Anesth \& Hosp D Serv, v. 18, n. 5, p. 391-99, Sept. 1960a. 
107. SIMPSON, H. E. Effects of suturing extraction wounds in macacus rhesus monkeys. J Oral Surg, Anesth \& Hosp D Serv, v. 18, n. 6, p. 461-64, Nov. 1960 b.

108. SIMPSON, H. E. Healing of surgical extraction wounds in macacus rhesus monkeys: I. The effect of burs. J Oral Surg, Anesth \& Hosp D Serv, v. 19, n. 1, p. 3-9, Jan. 1961a.

109. SIMPSON, H. E. Healing of surgical extraction wounds in macacus rhesus monkeys: II. The effect of chisels. J Oral Surg, Anesth \& Hosp D Serv, v. 19, n. 2, p. 126-29, Mar. $1961 b$.

110. SIMPSON, H. E. The healing of extraction wounds. Brit Dent J, v. 126, n. 12, p. 550-57, June 1969.

111.SMITH, N. A comparative histological and radiographic study of extraction socket healing in the rat. Aust Dent J, v. 19, n. 4, p. 250-54, Aug. 1974.

112.SMITH, R. L. The role of epithelium in the healing of experimental extraction wounds. J Dent Res, v. 37, n. 2, p. 187-194, Apr. 1958.

113.SOEHREN, S. E.; SWOL, R. L. V. The healing extraction site: a donor area for periodontal grafting material. J Periodontol, v. 50, n. 3, p. 128-33, Mar. 1979.

114.TAMAE, P. E. Avaliação da neoformação óssea do alvéolo dentário com plasma rico em plaquetas (PRP) em coelhos (Oryctolagus cuniculus). 2005. 91f. Dissertação (Mestrado) - Instituto de Ciências Biomédicas da Universidade de São Paulo, São Paulo, 2005.

115.TANAKA, S.; SHIMIZU, M.; DEBARI, K.; FURUYA, R.; KAWAWA, T.; SASAKI, T. Acute effects of ovariectomy on wound healing of alveolar bone after maxillary molar extraction in aged rats. Anat Rec, v. 262, n. 2, p. 203-212, Feb. 2001.

116.TODO, H. Healing mechanism of tooth extraction wounds in rats: I initial cellular response to tooth extraction in rats studied with ${ }^{3} \mathrm{H}$-Thymidine. Arch Oral Biol, v. 13, n. 12, p. 1421-27, 1968a. 
117.TODO, H. Healing mechanism of tooth extraction wounds in rats: II histochemical observations on hydrolytic and oxidative enzymes in tooth extraction wounds in the rat. Arch Oral Biol, v. 13, n. 12, p. 1429-43, 1968 b.

118.TRIPLETT, R. G.; SCHOW, S. R. Autologous bone grafts and endosseous implants: complementary techniques. J Oral Maxillofac Surg, v. 54, n. 4, p. 486-94, Apr. 1996.

119.VAN DEN BERGH, J. P. A.; TEN BRUGGENKATE, C. M.; TUINZING, D. B. Preimplant surgery of the bony tissues. J Prosthet Dent, v. 80, n. 2, p. 175-83, Aug. 1998.

120.VICTOR, J. O.; PINTO, R. S.; OKAMOTO, T.; CASTRO, A. L. Implante de gesso de paris em alvéolos dentais: estudo histológico em ratos. Rev Fac Odont Araçatuba, v. 4, n. 1, p. 71-79, 1975.

121.VICTOR, J. O.; MigUEL, R. M.; CALleStini, E. A.; CARVAlHO, A. Implante de gesso paris em alvéolos dentais de ratos: contribuição ao estudo radiográfico. Rev APCD, v. 31, n. 6, p. 382-86, nov./dez. 1977.

122.WANG, H. L.; KIYONOBU, K.; NEIVA, R. F. Socket augmentation: rationale and technique. Implant Dent, v. 13, n. 4, p. 286-93, Dec. 2004.

123.WIDMARK, G.; ANDERSSON, B.; IVANOFF, C. J. Mandibular bone graft in the anterior maxilla for single-tooth implants. Int J Oral Maxillofac Surg, v. 26, n. 2, p. 106-109, Apr. 1997.

124.YUGOSHI, L. I.; SAlA, M. A.; BRENTEGANI, L. G.; CARVALHO, T. L. L. Histometric study of socket healing after tooth extraction in rats treated with diclofenac. Braz Dent J, v. 13, n. 2, p. 92-96, 2002. 